\section{orm}

OAKRIDGE NATIONAL LABORATORY

LoGUHFD HATTH?

1.

1.
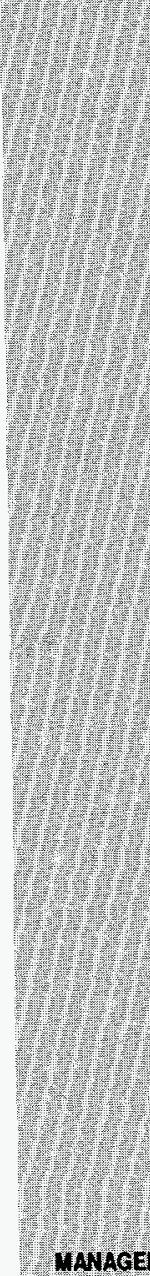

\footnotetext{
WAYAGED AWO OPERATED BY LOCKHEED MARTIN ENERGY RESEARCH CORPORATION FOA THE UNTED STATES DEPARTIUENT OF ENERGY

\section{LLNL MOX Fuel Lead Assemblies Data Report for the Surplus Plutonium Disposition Environmental Impact Statement}

\section{RECEIVED \\ SEP 291998 \\ 0871}

Fissile Materials Disposition Program

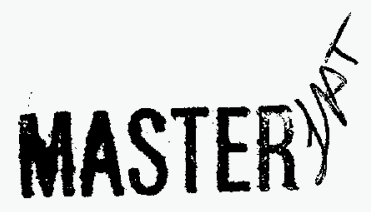

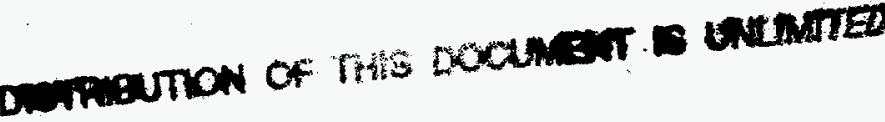


This report has been reproduced directly from the best available copy.

Available to DOE and DOE contractors from the Office of Scientific and Technical Information, P.O. Box 62, Oak Ridge, TN 37831; prices available from (423) 576-8401.

Available to the public from the National Technical Information Service, U.S. Department of Commerce, 5285 Port Royal Rd., Springfield, VA 22161.

\begin{abstract}
This report was prepared as an account of work sponsored by an agency of the United States Government. Neither the United States Govemment nor any agency thereot, nor any of their employees, makes any warranty, express or implied, or assumes any legal liability or responsibility for the accuracy, completeness, or usefulness of any information, apparatus, product, or process disclosed, or represents that its use would not infringe privately owned rights. Reference herein to any specific commercial product, process, or service by trade name, trademark, manufacturer, or otherwise, does not necessarily constitute or imply its endorsement, recommendation, or favoring by the United States Government or any agency thereof. The views and opinions of authors expressed herein do not necessarily state or reflect those of the United States Government or any agency thereol.
\end{abstract}




\section{DISCLAIMER}

Portions of this document may be illegible in electronic image products. Images are produced from the best available original document. 
Engineering Technology Division

\title{
LLNL MOX FUEL LEAD ASSEMBLIES DATA REPORT FOR THE SURPLUS PLUTONIUM DISPOSITION ENVIRONMENTAL IMPACT STATEMENT
}

\author{
Project Manager \\ S. R. Greene
}

Lead Assembly EIS Data Project Lead and Author

D. G. O'Connor

\section{Contributing Authors}

\section{ORNL}

S. E. Fisher

R. Holdaway

S. B. Ludwig

R. N. Morris

R. R. Rahn

J. Sease

V.S. White

J. J. Carbajo

K. L. McElhaney
LLNL

M. Bronson

W. Brough

T. Kato

H. Kahn

Date Published: August 1998

Prepared by

OAK RIDGE NATIONAL LABORATORY

Oak Ridge, Tennessee 37831

managed by

LOCKHEED MARTIN ENERGY RESEARCH CORP.

for the

U.S. DEPARTMENT OF ENERGY

under contract DE-AC05-96OR22464 
Page Intentionally Blank 


\section{CONTENTS}

Page

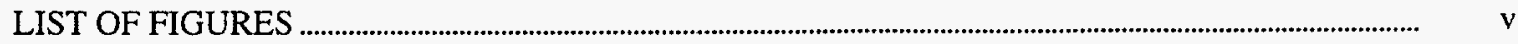

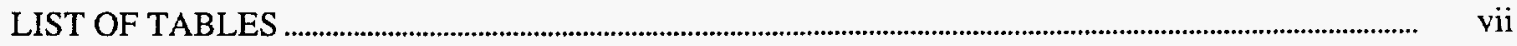

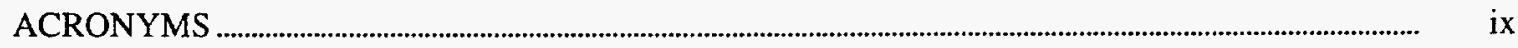

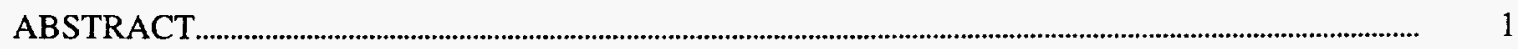

1. INTRODUCTION AND SCHEDULE ...............................................................................................................

2. SITE MAP AND THE LA FACILITY DESCRIPTION N.................................................................

2.1 LLNL FACILITIES ................................................................................................................... 9

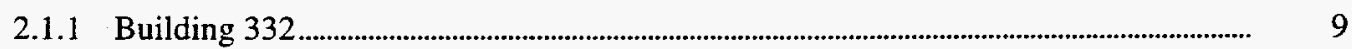

2.1.2 Building 334........................................................................................................................... 16

2.1.3 Building 335.................................................................................................................................... 19

2.2 SUPPORT LABORATORIES ............................................................................................................ 19

2.2.1 Scanning Electron Microscope and X-Ray Analysis Laboratory (Room 1313)........ $\quad 20$

2.2.2 Analytical Chemistry Laboratory (Rooms 1321 and 1321A)............................................. 20

2.2.3 Metallography Laboratory (Room 1322)................................................................................ 20

2.2.4 Analytical Chemistry Laboratory (Room 1329)............................................................... 20

2.2.5 Microprobe Laboratory and Sputtering Facility (Rooms 1330 and 1330A)................ $\quad 20$

2.2.6 Inspection Laboratory (Room 1362) .............................................................................. 21

2.2.7 Physical Testing Laboratory (Room 1369),........................................................................... 21

2.2.8 Plutonium Recovery and Waste Handling Laboratory (Room 1378) ............................. 21

3. PROCESS DESCRIPTIONS ..................................................................................................................................................... 23

3.1 PROCESS FLOW DIAGRAM.................................................................................................................... 23

3.2 WASTE MANAGEMENT FLOW DIAGRAMS............................................................................. 23

4. RESOURCE NEEDS.......................................................................................................................................... 29

4.1 CONSTRUCTION RESOURCE NEEDS.

4.2 OPERATIONAL RESOURCE NEEDS............................................................................................ $\quad 29$

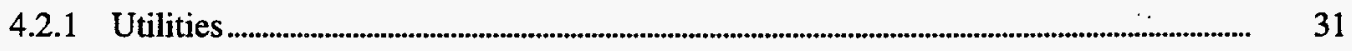

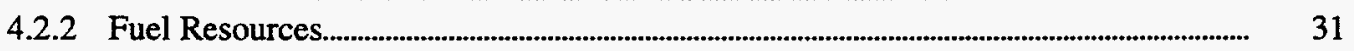

4.2.3 Water............................................................................................................................... 32

4.2.4 Process and Nonprocess Chemicals and Compounds ......................................................... $\quad 32$

4.2.5 Radioactive Process Materials....................................................................................................... 33

5. EMPLOYMENT REQUIREMENTS...................................................................................................... . 35

5.1 ANNUAL EMPLOYMENT REQUIREMENTS DURING OPERATION
OF THE LA FABRICATION FACILITY............................................................................................. 35

5.2 RADIATION DOSES (WHOLE BODY) TO INVOLVED WORKERS
DURING MODIFICATION OF THE LA FABRICATION FACILITY...............................

5.3 RADIATION DOSES (WHOLE BODY) TO INVOLVED WORKERS

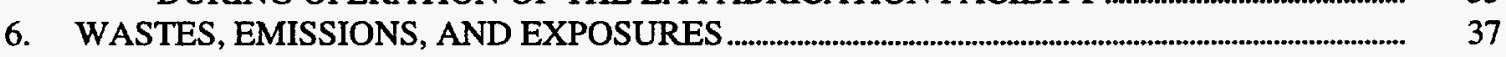

6.1 WASTES GENERATED DURING FACILITY MODIFICATION.............................................. 37

6.2 WASTES GENERATED DURING OPERATION OF THE FACILITY.................................. $\quad 37$

7. ACCIDENT ANALYSIS............................................................................................................................................... 39

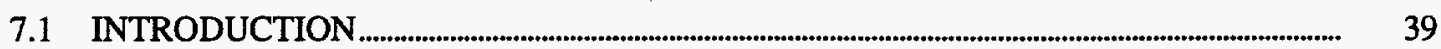

7.2 GENERAL APPROACH AND GENERIC DESIGN ASSUMPTIONS …................................ 39

7.2.1 Accident Analysis Approach ......................................................................................... 39

7.2.2 Facility Design Assumptions ............................................................................................................... 40

7.3 SELECTED EVENTS FOR THE LA EIS ANALYSIS......................................................................... 43

7.3.1 Criticality Event............................................................................................................................................ 43

7.3.2 Evaluation Basis Seismic Event............................................................................................. 45

7.3.3 Evaluation Basis Fire Event .......................................................................................................... 47 
7.3.4 Evaluation Basis Explosion Event ......................................................................................... 49

7.3.5 Beyond-Evaluation Basis Seismic Event ............................................................................. 51

7.3.6 Beyond-Evaluation Basis Major Building Fire................................................................... 51

7.4 EVALUATION OF POTENTIAL CHEMICAL SOURCE TERMS ........................................... 53

7.5 SITE SPECIFICS FOR THE LLNL BUILDING 332 ............................................................ 53

7.5.1 Stack Release Height ............................................................................................................................. 53

7.5.2 Evaluated Seismic Attributes ........................................................................................... 53

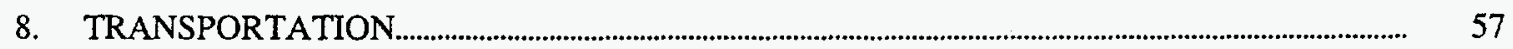

8.1 OPERATIONS-RELATED TRANSPORTATION REQUIREMENTS .................................... 57

8.1.1 Feed Materials ........................................................................................................................... 57

8.1.2 Fresh MOX Fuel Assemblies.................................................................................................... 57

8.1.3 Spent MOX Fuel Assemblies.......................................................................................................... 57

9. QUALITATIVE DECONTAMINATION AND DECOMMISSIONING ............................................ 63

9.1 INTRODUCTION ................................................................................................................................... 63

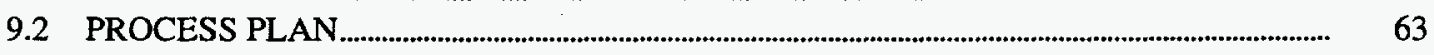

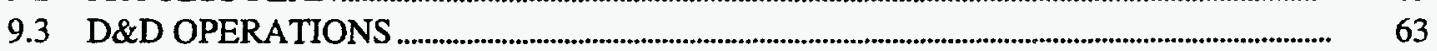

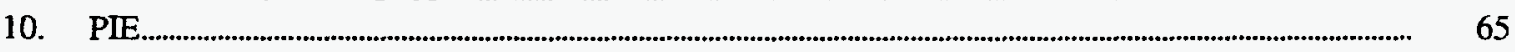

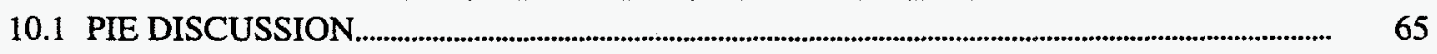

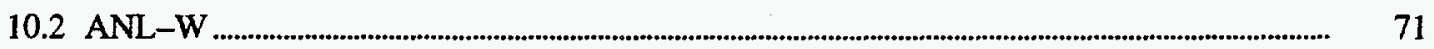

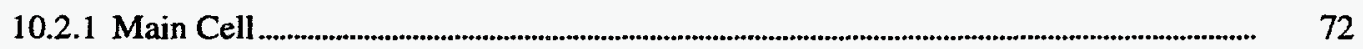

10.2.2 Decon Cell.................................................................................................................................... $\quad 72$

10.2.3 Metallographic Loading Box ……................................................................................................. $\quad 73$

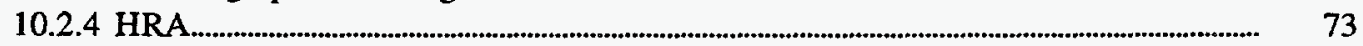

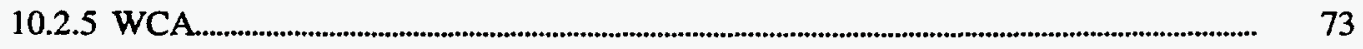

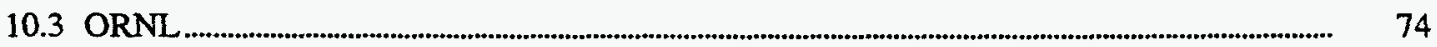

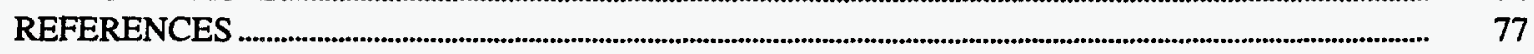

Appendix A-LA FUEL BUNDLE FABRICATION ................................................................................... A-1

Appendix B - LA EIS DATA REPORT ASSUMPTIONS.............................................................................. B-1

LLNL RESPONSE TO THE SUPPLEMENTAL LEAD TEST ASSEMBLY EIS DATA CALL........... S S-1 


\section{LIST OF FIGURES}

$\begin{array}{ll}\text { Figure } & \text { Page }\end{array}$

$1 \quad$ Simplified LA process diagram ....................................................................................................................

2 LA program schedule ................................................................................................................................. 5

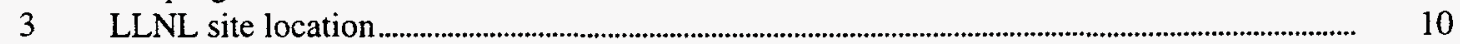

$4 \quad$ Residential and industrial areas outside the LLNL perimeter............................................................ 11

$5 \quad$ Layout of the LLNL site ......................................................................................................................

$6 \quad$ Layout of Superblock at LLNL ................................................................................................................ 13

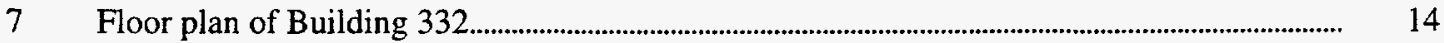

$8 \quad$ First-floor plan of Building 334.......................................................................................................................... $\quad 17$

9 Second-floor plan of Building 334......................................................................................................................... 18

10 Third-floor plan of Building 334 ......................................................................................... 19

11 LA MOX fuel flow sheet outline with annual throughputs............................................................ 24

12 Waste generated during LA MOX fuel fabrication facility operation ............................................ 26

13 ORNL site map.................................................................................................................................... 69

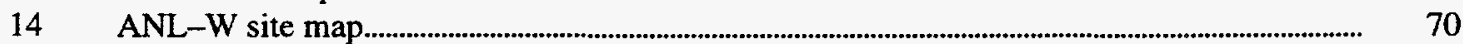

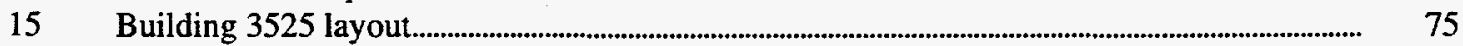

A.1 LA MOX fuel pellet flow sheet outline ............................................................................................................ A-3

A.2 LA MOX fuel $\mathrm{PuO}_{2}$ powder receipt and storage.......................................................................................... A-4

A.3 Detailed flow sheet of LA pellet fabrication............................................................................................... A-5

A.4 Detailed flow sheet of LA rod fabrication .................................................................................. A-6

A.5 Detailed flow sheet of LA bundle assembly (LWR) ....................................................................... A-7 
Page Intentionally Blank 


\section{LIST OF TABLES}

Table

Page

LA fabrication facility schedule ...............................................................................................................

LA testing schedule

LA MOX fuel material requirements.

Assumptions made to determine LA MOX fuel material requirements........................................ 7

LA MOX fuel fabrication requirements ....................................................................................................... 25

Resource needs during operation of the LA fabrication facility...................................................... $\quad 30$

Annual employment requirements during operation of the LA fabrication facility ................. 36

Assumptions used in consideration of staffing levels for the LA fabrication facility............... 36

Radiation doses (whole body) to involved workers during operation of the

LA fabrication facility

Estimated waste generated during operation of the LA fabrication facility...

Specific activities for process powders.

Estimated maximum station inventories for LA fabrication plant

Source term for the evaluation basis criticality event

Source term for the evaluation basis seismic event.

Source term for the evaluation basis fire

Source term for the evaluation basis explosion

Source term for beyond the evaluation basis seismic event

Source term for beyond the evaluation basis major building fire/building collapse.

Comparison of LA facility annual usage and reportable quantity per 40 CFR 302

Transportation of $\mathrm{PuO}_{2}$ to support LA fabrication.

Transportation of depleted $\mathrm{UO}_{2}$ to support LA fabrication.

Transportation of materials to support LA fabrication (LEU fuel assemblies)

Transportation of LAs to generic reactor site.

Fresh MOX fuel isotopic content.

Transportation of irradiated LAs to PIE site.

Spent MOX fuel isotopic content.

Examples of casks for LWR spent fuel

Estimated waste generated during LA PIE.

Radiation doses to involved workers during LA PIE

PIE estimates for EIS.

B.1 Assumptions used for the LA EIS data reports 
Page Intentionally Blank 


\section{ACRONYMS}

$\mathrm{ACL}$

AEC

AL

ALARA

ANL-W

ARF

ASTM

BRET

BWR

CAA

CCCTF

CEDE

CERCLA

CFA

CFR

$\mathrm{CH}$

CMC

CMR

CRBR

CS

CST

CWA

$D \& D$

$D \& R$

dc

DBE

DOE

DWPF

EA

EBE

EBR-I

EBR-II

EDS

EIS

EJ

EPA

ER

ETB

FAA

FCF

FCFS

FEMA

FFTF

FMEF

FMF

FONSI

FR

FTE

HAP

HEPA

HEU administrative control level

U.S. Atomic Energy Commission

analytical laboratory

as low as reasonably achievable

Argonne National Laboratory-West (at INEEL)

airborne release fraction

American Society for Testing and Materials

Breeder Reprocessing Engineering Test

boiling-water reactor

Clean Air Act

Core Conduction Cooldown Test Facility

committed effective dose equivalent

Comprehensive Environmental Response, Compensation, and Liability Act of 1980

Central Facilities Area (ANL-W)

Code of Federal Regulations

contact-handled

confirmatory measurement counter

Chemistry and Metallurgy Research

Clinch River Breeder Reactor

containment and surveillance

Chemical Science and Technology

Clean Water Act of 1972

decontamination and decommissioning

dismantling and rearrangement

direct current

design-basis earthquake

U.S. Department of Energy

defense waste processing facility

environmental assessment

evaluation based earthquake

Experimental Breeder Reactor-I

Experimental Breeder Reactor-II

Engineering Demonstration System

environmental impact statement

environmental justice

Environmental Protection Agency

Environmental Report

Engineering Test Bay

Fuel Assembly Area

Fuel Cycle Facility

Fueled Clad Fabrication System

Federal Emergency Management Agency

Fast-Flux Test Facility

Fuels and Materials Examination Facility

Fuel Manufacturing Facility

finding of no significant impact

fire resistive

full-time equivalent

hazardous air pollutant

high-efficiency particulate air

highly enriched uranium 


\begin{tabular}{|c|c|}
\hline HFEF/S & Hot Fuel Examination Facility South \\
\hline $\mathrm{HM}$ & heavy metal \\
\hline HP & Health Physics \\
\hline HPFL & High-Performance Fuel Laboratory \\
\hline HVAC & heating, ventilating, and air conditioning \\
\hline HWMA & Hazardous Waste Management Act of 1983 \\
\hline $\mathrm{I} \& \mathrm{C}$ & Instrumentation and Controls \\
\hline IDAPA & Idaho Administrative Procedures Act \\
\hline IFEL & Irradiated Fuels Examination Laboratory \\
\hline IFR & Integral Fast Reactor \\
\hline IMGA & Irradiated Microsphere Gamma Analyzer \\
\hline INEEL & Idaho National Engineering and Environmental Laboratory \\
\hline INRAD & Intrinsic Radiation Bay \\
\hline LA & lead assembly \\
\hline LACEF & Los Alamos Critical Experiments Facility \\
\hline LANL & Los Alamos National Laboratory \\
\hline LLMW & low-level mixed waste \\
\hline LLRW & low-level radioactive waste \\
\hline LLW & low-level waste \\
\hline LLNL & Lawrence Livermore National Laboratory \\
\hline LMES & Lockheed Martin Energy Systems, Inc. \\
\hline LMITCO & Lockheed Martin Idaho Technologies Company \\
\hline LTA & lead-test assembly \\
\hline LUA & lead-use assembly \\
\hline LWR & light-water reactor \\
\hline MAA & Material Access Area \\
\hline $\mathrm{M} \& \mathrm{C}$ & Metals and Ceramics \\
\hline MC\&A & material control and accountability \\
\hline MD & Office of Fissile Materials Disposition (DOE) \\
\hline MFP & multiple fission products \\
\hline MOX & mixed oxide \\
\hline MT & metric ton \\
\hline $\mathrm{MW}$ & mixed waste \\
\hline NDA & nondestructive assay \\
\hline NDT & nondestructive testing \\
\hline NEPA & National Environmental Policy Act of 1969 \\
\hline NGVD & National Geodetic Vertical Datum \\
\hline NMS\&S & Nuclear Material Stabilization and Storage Division \\
\hline NMSS & Office of Nuclear Material Safety and Safeguards \\
\hline NPDES & National Pollutant Discharge Elimination System \\
\hline NRC & Nuclear Regulatory Commission \\
\hline ORNL & Oak Ridge National Laboratory \\
\hline ORR & Oak Ridge Reservation \\
\hline OSR & Operational Safety Requirements \\
\hline PA & protected area \\
\hline PC & Performance Category \\
\hline PDAC & pit disassembly and conversion \\
\hline PF & Plutonium Facility \\
\hline PFP & Plutonium Finishing Plant \\
\hline PGA & peak ground acceleration \\
\hline PIDAS & Perimeter Intrusion and Detection Assessment System \\
\hline PIE & postirradiation examination \\
\hline PPE & personal protective equipment \\
\hline PSF & Plutonium Storage Facility \\
\hline
\end{tabular}




$\begin{array}{ll}\text { PWR } & \text { pressurized-water reactor } \\ \text { QA } & \text { quality assurance } \\ \text { R\&D } & \text { research and development } \\ \text { RAMROD } & \text { Radioactive Materials Research, Operations, and Demonstration Facility } \\ \text { RCRA } & \text { Resource Conservation and Recovery Act of 1976 } \\ \text { RCT } & \text { Radiological Control Technician } \\ \text { RF } & \text { respirable fraction } \\ \text { RH } & \text { remote handled } \\ \text { RLWTF } & \text { Radioactive Liquid Waste Treatment Facility } \\ \text { RMA } & \text { Radioactive Material Area } \\ \text { RMAL } & \text { Radioactive Materials Analytical Laboratory } \\ \text { ROD } & \text { record of decision } \\ \text { RPSF } & \text { Radioisotope Power Systems Facility } \\ \text { RSSF } & \text { Radioactive Sodium Storage Facility } \\ \text { RSWF } & \text { Radioactive Scrap and Waste Facility } \\ \text { RWMC } & \text { Radioactive Waste Management Complex (INEEL) } \\ \text { S\&D } & \text { storage and disposition } \\ \text { S\&S } & \text { safeguards and security } \\ \text { SAF } & \text { secure automated facility } \\ \text { SCDHEC } & \text { South Carolina Department of Health and Environmental Control } \\ \text { SEM } & \text { scanning electron microscope } \\ \text { SIP } & \text { Space Isotope Program } \\ \text { SNF } & \text { spent nuclear fuel } \\ \text { SNFM } & \text { spent nuclear fuel material } \\ \text { SNM } & \text { special nuclear material } \\ \text { SPSP } & \text { Space Power Systems Project } \\ \text { SRS } & \text { Savannah River Site } \\ \text { SRTC } & \text { Savannah River Technology Center } \\ \text { SSC } & \text { structure, systems, and components } \\ \text { SST } & \text { safe secure transport } \\ \text { TA } & \text { Technical Area } \\ \text { TAP } & \text { toxic air pollutant } \\ \text { TEDE } & \text { total effective dose equivalent } \\ \text { TREAT } & \text { Transient Reactor Test Facility } \\ \text { TRU } & \text { transuranic } \\ \text { TSCA } & \text { Toxic Substances Control Act } \\ \text { TSDF } & \text { treatment, storage, and/or disposal facility } \\ \text { UBC } & \text { Uniform Building Code } \\ \text { USF } & \text { Uranium Solidification Facility } \\ \text { W } & \text { Westinghouse } \\ \text { WAG } & \text { Waste Area Group } \\ \text { WCL } & \text { Waste Characterization Laboratory } \\ \text { WCRRF } & \text { Waste Characterization, Reduction, and Repackaging Facility } \\ \text { WG } & \text { weapons grade } \\ \text { WIPP } & \text { Waste Isolation Pilot Plant } \\ \text { WOC } & \text { White Oak Creek } \\ \text { WRAP } & \text { Waste Receiving and Processing Plant } \\ \text { Westinghouse Savannah River Company } & \text { Zero Power Physics Reactor } \\ & \end{array}$





\title{
LLNL MOX FUEL LEAD ASSEMBLIES DATA REPORT FOR THE SURPLUS PLUTONIUM DISPOSITION ENVIRONMENTAL IMPACT STATEMENT
}

\author{
Project Manager \\ S. R. Greene
}

\author{
Lead Assembly EIS Data Project Lead and Author \\ D. G. O'Connor
}

\begin{abstract}
The purpose of this document is to support the U.S. Department of Energy (DOE) Fissile Materials Disposition Program's preparation of the draft surplus plutonium disposition environmental impact statement. This is one of several responses to data call requests for background information on activities associated with the operation of the lead assembly (LA) mixed-oxide (MOX) fuel fabrication facility.

The DOE Office of Fissile Materials Disposition (DOE-MD) has developed a "dual-path" strategy for disposition of surplus weapons-grade plutonium. One of the paths is to disposition surplus plutonium through irradiation of MOX fuel in commercial nuclear reactors. MOX fuel consists of plutonium and uranium oxides $\left(\mathrm{PuO}_{2}\right.$ and $\left.\mathrm{UO}_{2}\right)$, typically containing $95 \%$ or more $\mathrm{UO}_{2}$.

DOE-MD requested that the DOE Site Operations Offices nominate DOE sites that meet established minimum requirements that could produce MOX LAs. Six initial site combinations were proposed: (1) Argonne National Laboratory-West (ANL-W) with support from Idaho National Engineering and Environmental Laboratory (INEEL), (2) Hanford, (3) Los Alamos National Laboratory (LANL) with support from Pantex, (4) Lawrence Livermore National Laboratory (LLNL), (5) Oak Ridge Reservation (ORR), and (6) Savannah River Site (SRS). After further analysis by the sites and DOE-MD, five site combinations were established as possible candidates for producing MOX LAs: (1) ANL-W with support from INEEL, (2) Hanford, (3) LANL, (4) LLNL, and (5) SRS. Pantex was removed as a supporting organization to LANL because Pantex did not have facilities available that met the desired programmatic criteria. One of the criteria was that existing buildings would be used for the mission. Pantex had no available existing buildings that it was willing to propose for this limited mission. ORR was removed by DOE-MD from consideration because it lacked adequate Safeguards and Security (S\&S) Category I facilities, which would limit the quantity of material that could be processed at a given time.

LLNL has proposed an LA MOX fuel fabrication approach that would be done entirely inside an S\&S Category I area. This includes receipt and storage of $\mathrm{PuO}_{2}$ powder, fabrication of MOX fuel pellets, assembly of fuel rods and bundles, and shipping of the packaged fuel to a commercial reactor site. Support activities will take place within a Category I area.

Building 332 will be used to receive and store the bulk $\mathrm{PuO}_{2}$ powder, fabricate MOX fuel pellets, and assemble fuel rods. Building 334 will be used to assemble, store, and ship fuel bundles. Only minor modifications would be required of Building 332. Uncontaminated glove boxes would need to be removed, petition walls would need to be removed, and minor modifications to the ventilation system would be required.

A commercial reactor operator has not been identified for the LA irradiation. Postirradiation examination (PIE) of the irradiated fuel will take place at either Oak Ridge National Laboratory or ANL-W. The only modifications required at either PIE site would be to accommodate full-length irradiated fuel rods.

Results from this program are critical to the overall plutonium distribution schedule.
\end{abstract}





\section{INTRODUCTION AND SCHEDULE}

As part of the overall mission to disposition weapons-grade (WG) plutonium as fuel for commercial nuclear power plants, a lead assembly (LA) program is needed to qualify mixed-oxide (MOX) fuel as a safe and reliable fuel. The LA program will provide key data regarding the performance of MOX fuel in U.S. commercial reactors and supply information needed to modify current U.S. Nuclear Regulatory Commission (NRC) licenses. The program will also provide information necessary to validate and verify computer codes used in the reactor core design and accident analyses. In addition to qualifying the MOX fuel and validating and verifying the codes, the LA program will serve to verify that the United States can indeed execute each technical step necessary in the process of dispositioning plutonium as MOX fuel, except NRC licensing of facilities.

A simplified diagram showing each of the required process steps for the LA program is shown in Fig. 1. The LA program will include every step needed to complete the reactor portion of the plutonium disposition mission (including transportation and storage), with the exception of placement of the spent fuel in the geologic repository. In all likelihood, some of the LA program MOX fuel bundles will make their way to the geologic repository, but subsequent disposal in the repository is analyzed in other environmental documents. Detailed descriptions of the process required to fabricate MOX fuel, irradiate the fuel, and perform postirradiation examinations (PIE) of the spent fuel will be provided in Chaps. 3 and 10.

As previously stated, the goals of the LA program are to qualify the MOX fuel, confirm codes, and demonstrate that the United States can perform the steps necessary to disposition plutonium using MOX fuel. For the LA program these steps start with receipt of acceptable plutonium oxide $\left(\mathrm{PuO}_{2}\right)$ that is derived from "pits" and processed in the United States. At each step in the process, safeguards and security (S\&S) measures, material control and accountability (MC\&A) measures, transportation issues, storage issues, and material handling issues will be addressed. As shown in Fig. 1, the $\mathrm{PuO}_{2}$ is mixed and blended with

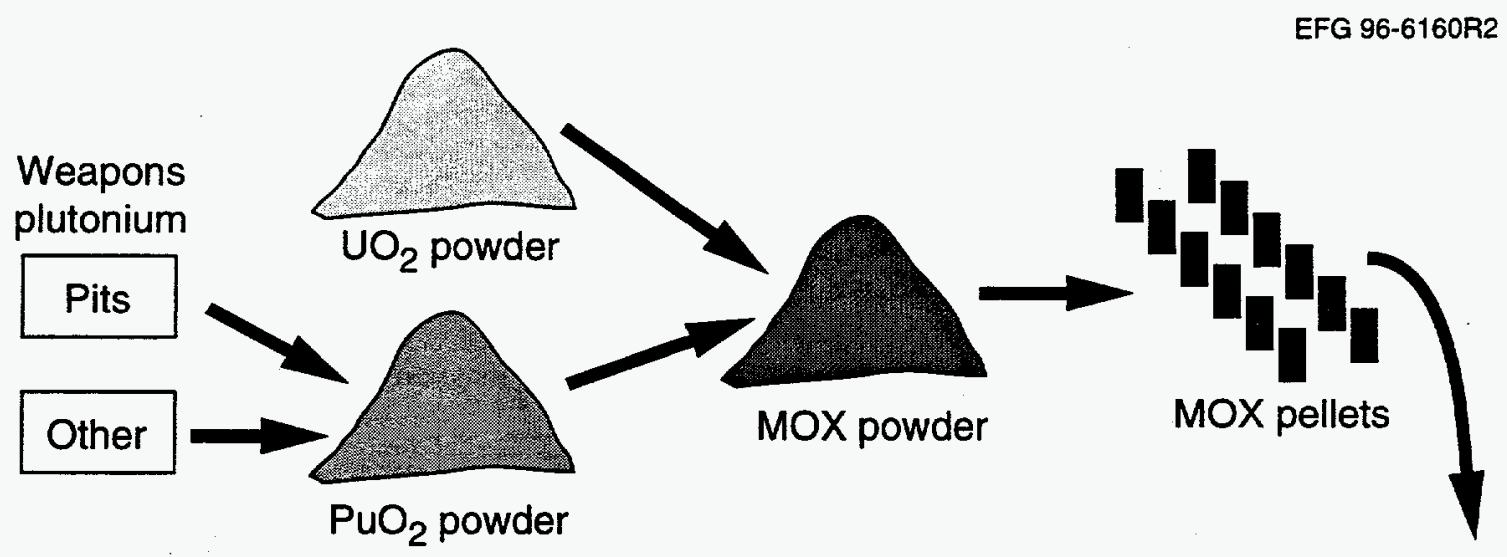

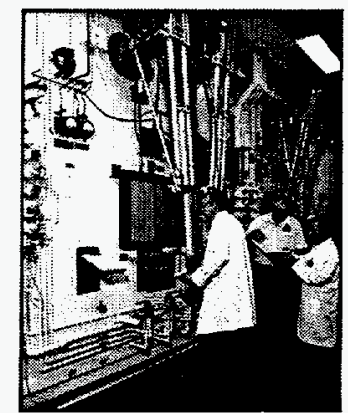

PIE

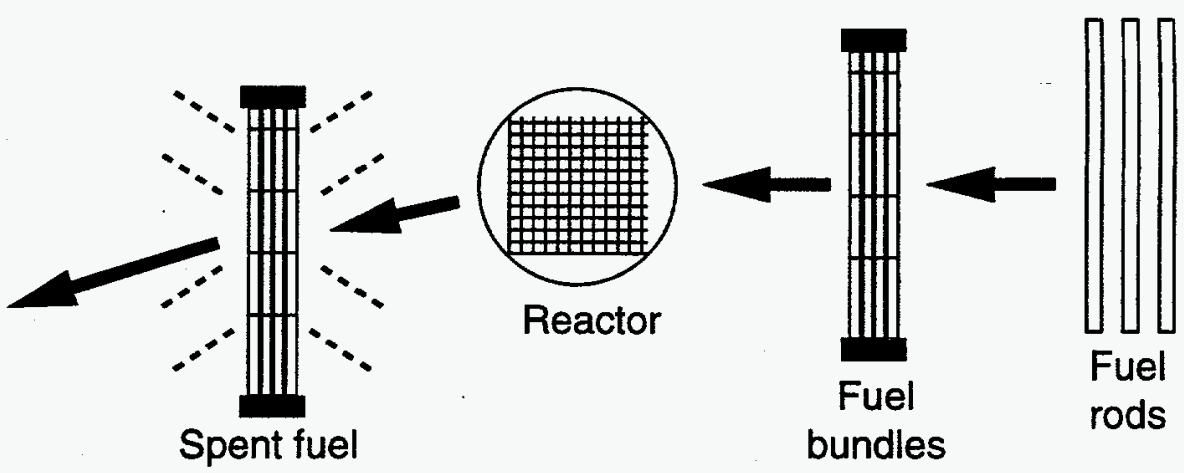

Fig. 1. Simplified LA process diagram. 
uranium oxide $\left(\mathrm{UO}_{2}\right)$ to arrive at the fissile content requested by the utility fuels engineer. Pellets are then pressed, sintered, and assembled into rods. The rods are then assembled into fuel assemblies and packaged for shipping to the reactor site for irradiation. After irradiating the fuel for one cycle, some of the rods are removed from the irradiated assemblies and taken to a laboratory for PIE. Additional rods will be removed after the second, third, and fourth cycles (if the chosen reactor has a third and fourth cycle), and PIE will be performed to confirm that the structural integrity of the MOX fuel, cladding, and assembly materials is maintained and that the computer codes accurately predict the fuel performance and evolution of fission products.

Figure 2 shows the anticipated schedule for the LA program relative to the plutonium disposition mission. Los Alamos National Laboratory (LANL) is currently developing the processes necessary to fabricate MOX fuel. The U.S. Department of Energy Office of Fissile Materials Disposition (DOE-MD) plans to choose a consortium before the end of 1998 to disposition excess plutonium using reactors, at which time this consortium will choose the DOE site(s) and associated facilities to fabricate the LA MOX fuel. At that same time the consortium will begin design, licensing, and construction of the mission MOX fuel fabrication facility. The fabrication process used for the LAs will be as close as possible to that of the MOX fabricator in the consortium. Fabrication of the LA MOX fuel will begin in late 2002. The first LAs [shown as lead-test assemblies (LTAs) in Fig. 2] will be available for insertion in a commercial reactor in late 2003. PIE will begin 6 months after completion of the first reactor cycle with results available by the end of the second LA reactor cycle. After two LA cycles (18-24 months per cycle), the mission MOX fuel fabrication will begin if the PIE produces satisfactory confirmation of fuel performance. PIE will be done after each LA reactor cycle to ensure that fuel performance meets or exceeds expected results. Table 1 provides the schedules associated with the design, modification, operation, decontamination and decommissioning (D\&D), and/or conversion of the LA MOX fuel fabrication facility. Table 2 provides the time frames associated with the LA testing.

To maintain LA fabrication capability, should it be needed for any reason, the LA fuel fabrication facility will be maintained in standby for 4 years between the end of the facility's scheduled operation and its scheduled D\&D. During this time the capability to produce lead assemblies will be maintained.

A maximum of ten LAs will be produced to meet the LA program mission goals. Table 3 provides the anticipated quantities of constituent materials that will be needed annually and in total to complete the LA program. Several assumptions were made to arrive at the quantities in Table 3, and these are listed in Table 4.

A total of four assemblies are anticipated to be required for use as LAs in the chosen mission reactor. It is possible a second set of four LAs will be needed for either a second reactor or for use in the same reactor. In addition, sufficient rods will be produced to assemble two archive LAs.

A total of eight LA MOX fuel assemblies will be temporarily stored in the LA fabrication facility until they are shipped to the reactors for irradiation. The rods for the two remaining assemblies, and possibly the MOX rods from four assemblies not used, will be retained in the LA shipping and storage area as archive rods. These archive rods will be used if needed as replacement rods in the reactor or they may be used for tests of the LA MOX fuel fabrication process. If they are not needed, or until they are needed, these rods will be stored at the LA MOX fuel fabrication facility until the end of that facility's mission. The LAs will then be shipped to the mission MOX fabrication facility for storage until the end of the Fissile Materials Disposition Program, at which time they will either be retained by the consortium as active rods, or irradiated in a mission reactor.

Due to the uncertainty associated with the final design of the LA MOX fuel, the assemblies may consist of either all MOX fuel rods or a combination of low-enriched uranium (LEU) and MOX rods. A bounding approach was taken in considering environmental impacts. The bounds that were considered for this report were based on the number of MOX fuel rods per assembly. A lower bound of one-third of the fuel rods being MOX rods results in the need to ship the remaining two-thirds of the required LEU rods to the LA fuel fabrication facility. The upper bound of all MOX rods in the assembly provides the bounding case for resource needs, safety considerations, accident analyses, and postirradiation examination. 
ORNL-DWG 97-1915R3 EFG

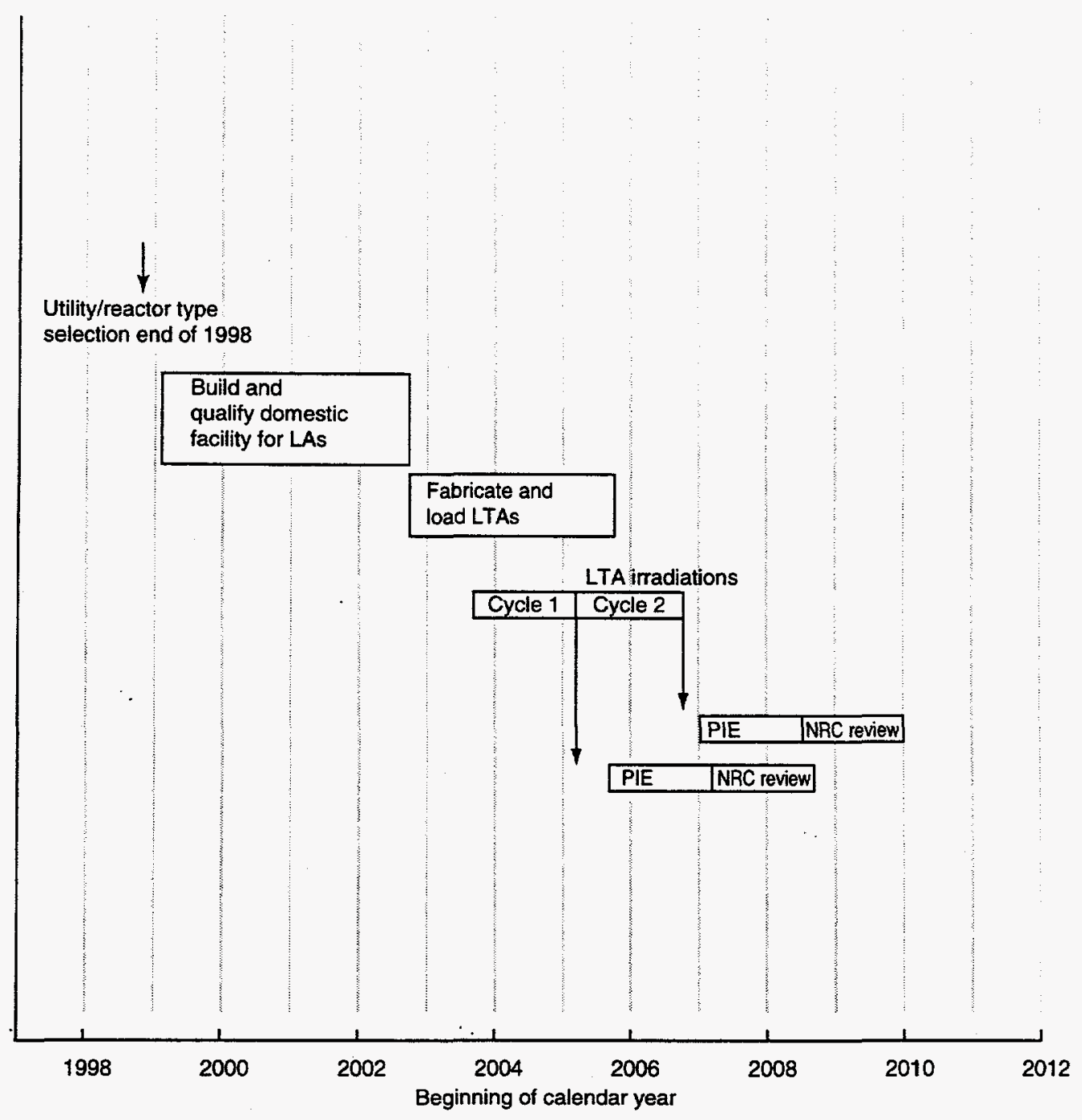

Fig. 2. LA program schedule. 
Table 1. LA fabrication facility schedule

\begin{tabular}{ll}
\hline \multicolumn{1}{c}{ Activity } & \multicolumn{1}{c}{$\begin{array}{c}\text { Time frame } \\
\text { (beginning and end) }\end{array}$} \\
\hline Equipment procured & June 2000-December 2001 \\
Facility design & February 1999-January 2001 \\
Facility permitting & January 2000-January 2002 \\
Facility modification & January 2000-February 2002 \\
Facility startup & February 2002-October 2002 \\
LA fabrication (operation) & October 2002-October 2005 \\
LA fabrication facility standby & October 2005-January 2010 \\
D\&D and/or conversion phase & January 2010-January 2013 \\
\hline
\end{tabular}

Table 2. LA testing schedule

\begin{tabular}{ll}
\hline \multicolumn{1}{c}{ Activity } & \multicolumn{1}{c}{ Time frame (beginning and end) } \\
\hline Irradiation & $\begin{array}{l}\text { September 2003-October 2006 } \\
\text { Removal (cooldown) } \\
\text { March 2005-October 2006 (6 months cooldown after removal } \\
\text { before PIE, March 2005-April 2007) } \\
\text { PIE }\end{array} \quad \begin{array}{l}\text { September 2005-October 2008 (about 18 months for PIE for each } \\
\text { reactor cycle) }\end{array}$ \\
\hline
\end{tabular}

Table 3. LA MOX fuel material requirements

\begin{tabular}{lccccr}
\hline Material & $\begin{array}{c}\text { Startup } \\
\text { requirement }\end{array}$ & $\begin{array}{c}\text { Startup } \\
\text { scrap/recyclable }\end{array}$ & $\begin{array}{c}\text { Maximum } \\
\text { annual } \\
\text { requirement }\end{array}$ & $\begin{array}{c}\text { Maximum } \\
\text { annual scrap/ } \\
\text { recyclable }\end{array}$ & $\begin{array}{c}\text { Total } \\
\text { quantity }\end{array}$ \\
\hline $\begin{array}{l}\text { Plutonium, kg } \\
\text { heavy metal (HM) }\end{array}$ & 21 & 13 & 120 & 20 & 321 \\
$\begin{array}{l}\text { Depleted uranium, } \\
\text { kg HM }\end{array}$ & 867 & 250 & 2,400 & 400 & 6,867 \\
$\begin{array}{l}\text { Pellets } \\
\text { Rods }\end{array}$ & 221,760 & & 532,224 & & $1,552,320$ \\
Bundles & 440 & & 1,162 & & 3,344 \\
\end{tabular}

Note: In the event LEU rods are used in place of some MOX rods in the assembly, the total quantities of plutonium will be reduced by the amount of LEU introduced. The maximum contribution of LEU rods is twothirds of the total assembly rods. 
Table 4. Assumptions made to determine LA MOX fuel material requirements

1. Material and process requirements are based on producing pressurized-water reactor (PWR) fuel.

2. $\mathrm{PuO}_{2}$ powder will meet the American Society for Testing and Materials (ASTM) specification C 757-90 as received.

3. Depleted $\mathrm{UO}_{2}$ powder will meet the ASTM specification as received.

4. Depleted $\mathrm{UO}_{2}\left(\right.$ no $\left.\mathrm{PuO}_{2}\right)$ will be used to perform all system shakedown tests before introducing plutonium.

5. Table 3 is in terms of $\mathrm{HM}$. The factor for converting $\mathrm{PuO}_{2}$ and depleted $\mathrm{UO}_{2}$ to $\mathrm{HM}$ is $88 \%$.

6. All waste plutonium will be canned and sent to the Immobilization Program for final disposition.

7. All plutonium scrap will be recycled using a dry process.

8. All liquid wastes generated are ancillary to the base process (i.e., laundry, mop water, etc.).

9. Sintering furnaces will stay at temperature during the entire 3-year mission and 1-year startup.

10. Sintering furnaces will be purged with a mixture of argon and $6 \%$ hydrogen at a rate of $10 \mathrm{~L} / \mathrm{min}$.

11. Powder glove boxes will be purged with nitrogen to reduce the potential for oxidizing $\mathrm{UO}_{2}$.

12. All calculated numbers have a precision of no more than two significant figures.

13. Homogenization of the $\mathrm{PuO}_{2}$ will be done at the $\mathrm{LA}$ fuel fabrication facility, as will gallium removal operations. 
Page Intentionally Blank 


\section{SITE MAP AND THE LA FACILITY DESCRIPTION}

\subsection{LLNL FACILITIES}

The geographical coordinates of the LLNL site are $37^{\circ} 41$ min north latitude and $121^{\circ} 41$ min west longitude. Building 332 is proposed for plutonium oxide receiving and storage and Building 334 for bundling, fuel bundle storage, and fuel bundle packaging and shipping. Building 335 is proposed to be used for assembly and testing of equipment, storage of spare parts and supplies, and electrical and mechanical shop areas. All three buildings are located in LLNL's Superblock, a $500-\mathrm{ft}$ by $700-\mathrm{ft}$ protected area surrounded by an alarmed double security fence. Laboratory security forces control access into the Superblock and independently control access into the Radioactive Material Area (RMA) of Building 332.

No significant wastes, emissions, and exposures will be generated during modification of the facilities to accommodate this activity. The laboratories and bays that will be modified contain "clean equipment" that can be removed and used elsewhere at the laboratory. No radiation doses above background are anticipated during the facility modification. The locations of these facilities are shown in Figs. 3-6.

\subsubsection{Building 332}

The Plutonium Facility (Building 332) is located inside LLNL's Superblock, a $500-\mathrm{ft}$ by 700 -ft protected area (PA) surrounded by an alarmed double security fence. Laboratory security forces control access into the Superblock and independently control access into the Radioactive Materials Area (RMA) of Building 332.

The Plutonium Facility, shown in Fig. 7, comprises several buildings. These buildings-constructed at different times over the last three decades-comprise Increments 1 through 4, the Plenum Building, and an office structure.

Increment $1\left(45,961 \mathrm{ft}^{2}\right.$, including loft), which became operational in 1961 , is the larger section of Building 332 and is two stories high. The first floor contains offices, an airlock, plutonium-handling laboratories, mechanical shops, a mechanical equipment room, change rooms, and the laboratory's Central Storage Vault. The second floor (loft) houses all glove box, fume hood, and loft exhaust ventilation systems for Increment 1, including exhaust fans, motors, and high-efficiency particulate air (HEPA) filters.

Increment 2 is a small, nonradioactive-materials laboratory located adjacent to Increment 1 . This laboratory contains vacuum furnaces to dry salt (a calcium chloride and calcium fluoride mixture) and a glove box line. A special furnace in the glove box is used to sparge the dried salt with hydrogen chloride gas.

Increment $3\left(21,963 \mathrm{ft}^{2}\right.$, including basement and portal), to the east of Increment 1 , was completed in 1977 and consists of one ground-level floor and a basement. An airlock and corridor connect Increments 1 and 3. Two plutonium storage vaults and several plutonium-handling laboratories are located on the ground floor. The basement contains ventilation equipment, storage tanks for emergency water supplies, emergency power, utilities, and support equipment for experiments conducted in Increment 3.

Increment 4 (Room 1309) was added in 1977 to expand the Cold Machine Shop (Room 1305).

The Plenum Building was constructed in 1981 and is freestanding. The building houses dual plenum chambers, each provided with a deluge water sprinkler, demister, in-series two-stage HEPA filters, exhaust fans, and motors. The building also houses stack-monitoring equipment.

A single-story office addition ( $85 \mathrm{ft}$ by $165 \mathrm{ft}$ by $12 \mathrm{ft}$ high) was completed in 1993 . This addition to the east of Room 1200 provides office space for facility staff, meeting rooms, an equipment room, and a Protective Force station. It houses administrative staff who directly support the plutonium facility and provides high-security space for a Secondary Alarm Station (SAS). The purpose of the SAS is to provide alarm and video monitoring for Protective Force officers and to provide communications to other facilities. No special nuclear material (SNM) is received, handled, or processed in the office addition.

The Plutonium Facility has been determined to be a Hazard Category 2 facility according to DOE (1992a), which corresponds to a Moderate Hazard Usage Category according to Kennedy (1990). The facility contains Performance Category (PC) 3 structure, systems, and components (SSCs). For PC 3 


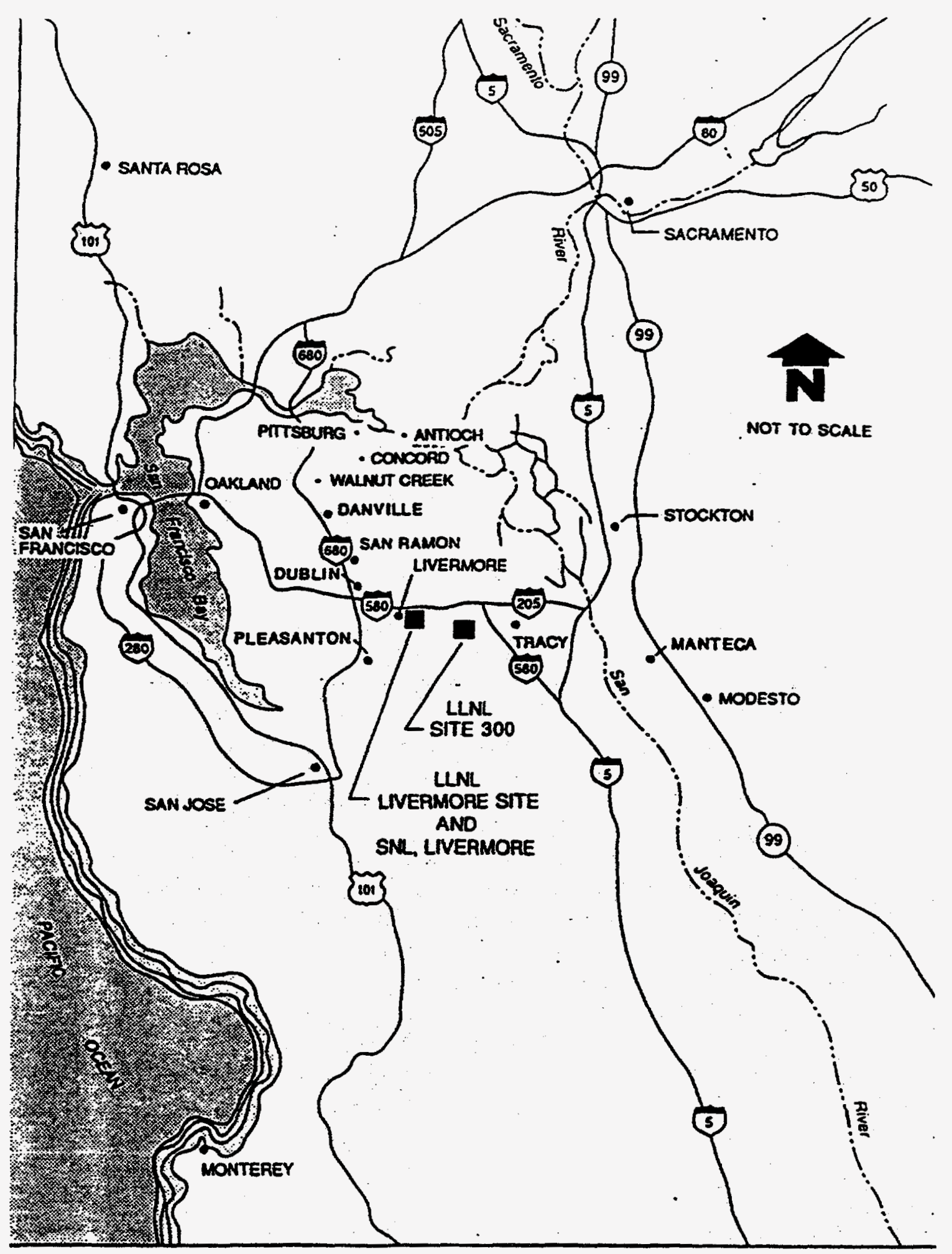

Fig. 3. LLNL site location. 


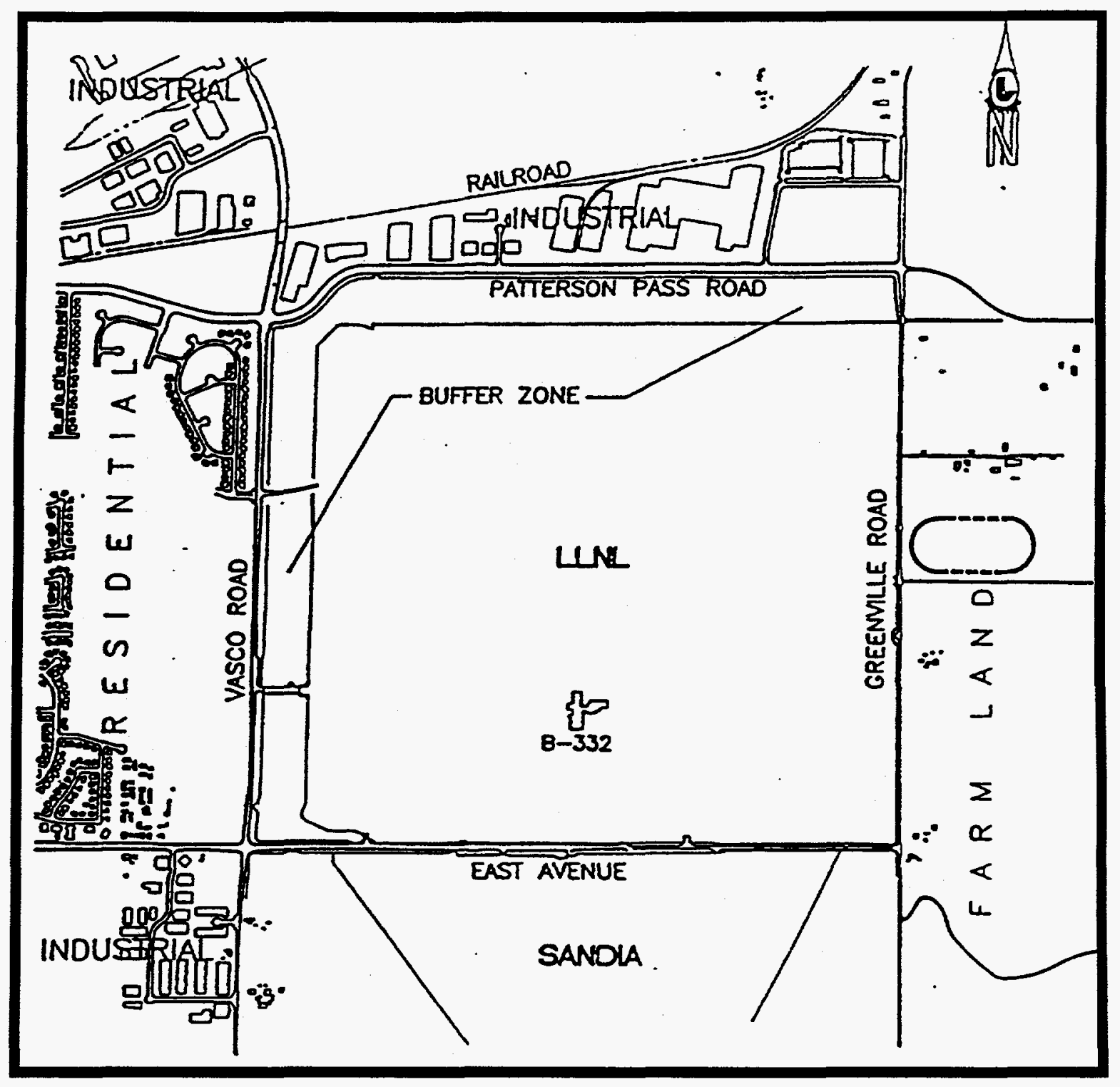

Fig. 4. Residential and industrial areas outside LLNL perimeter. 


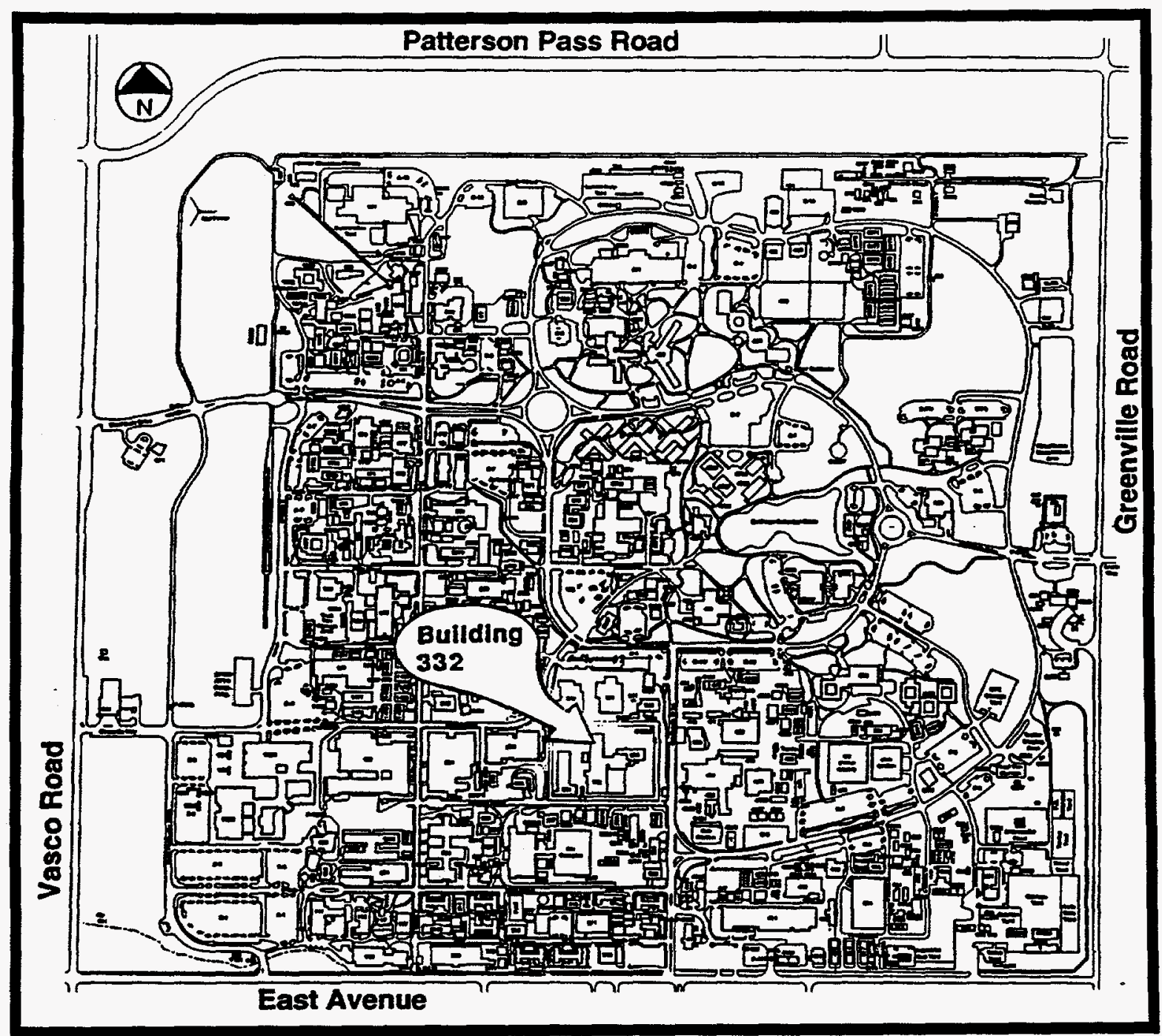

Fig. 5. Layout of LLNL site. 
ORNL 98-2467 EFG

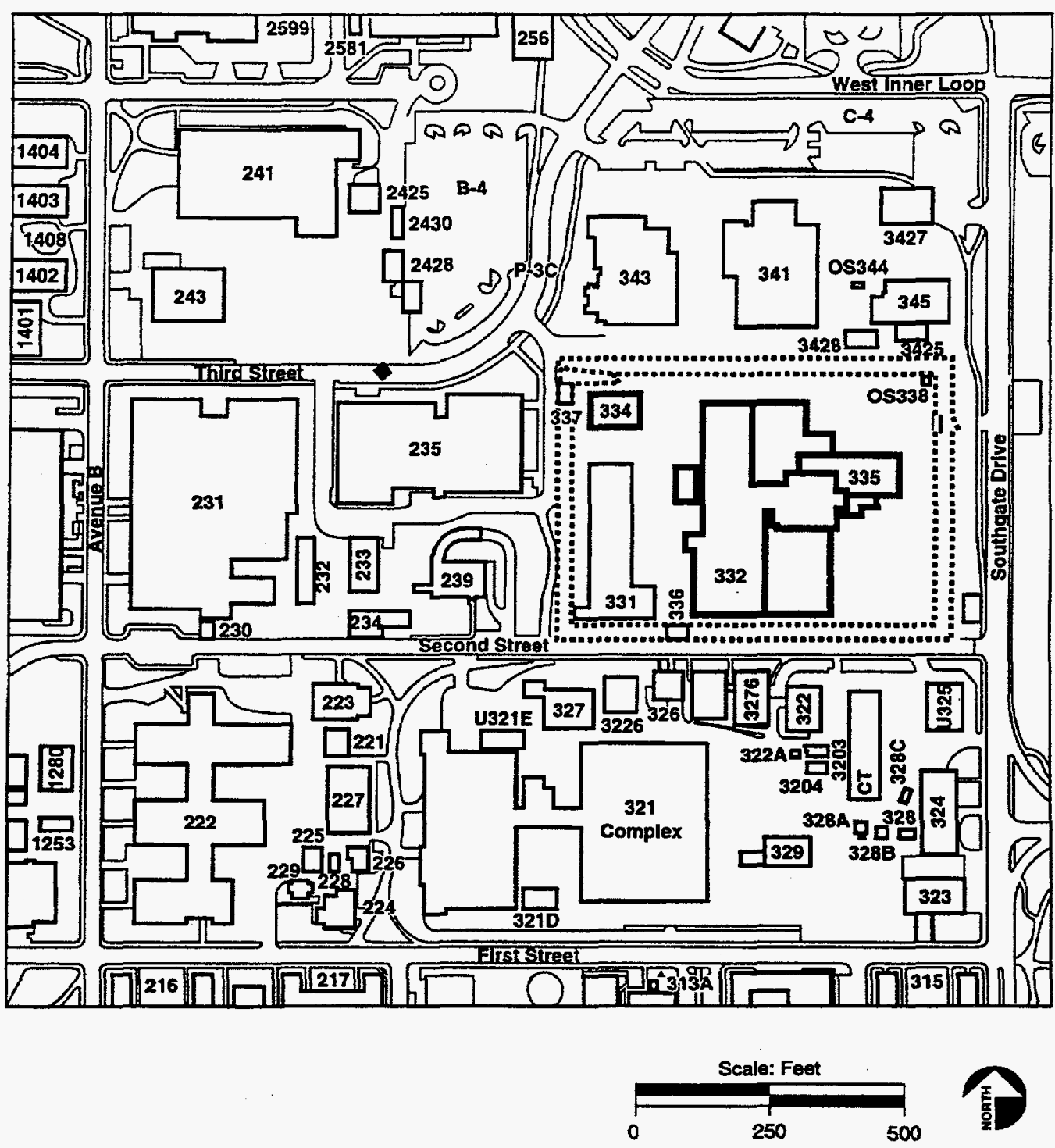

Source: LLNL Technical Information Department, 1998

Fig. 6. Layout of Superblock at LLNL. 


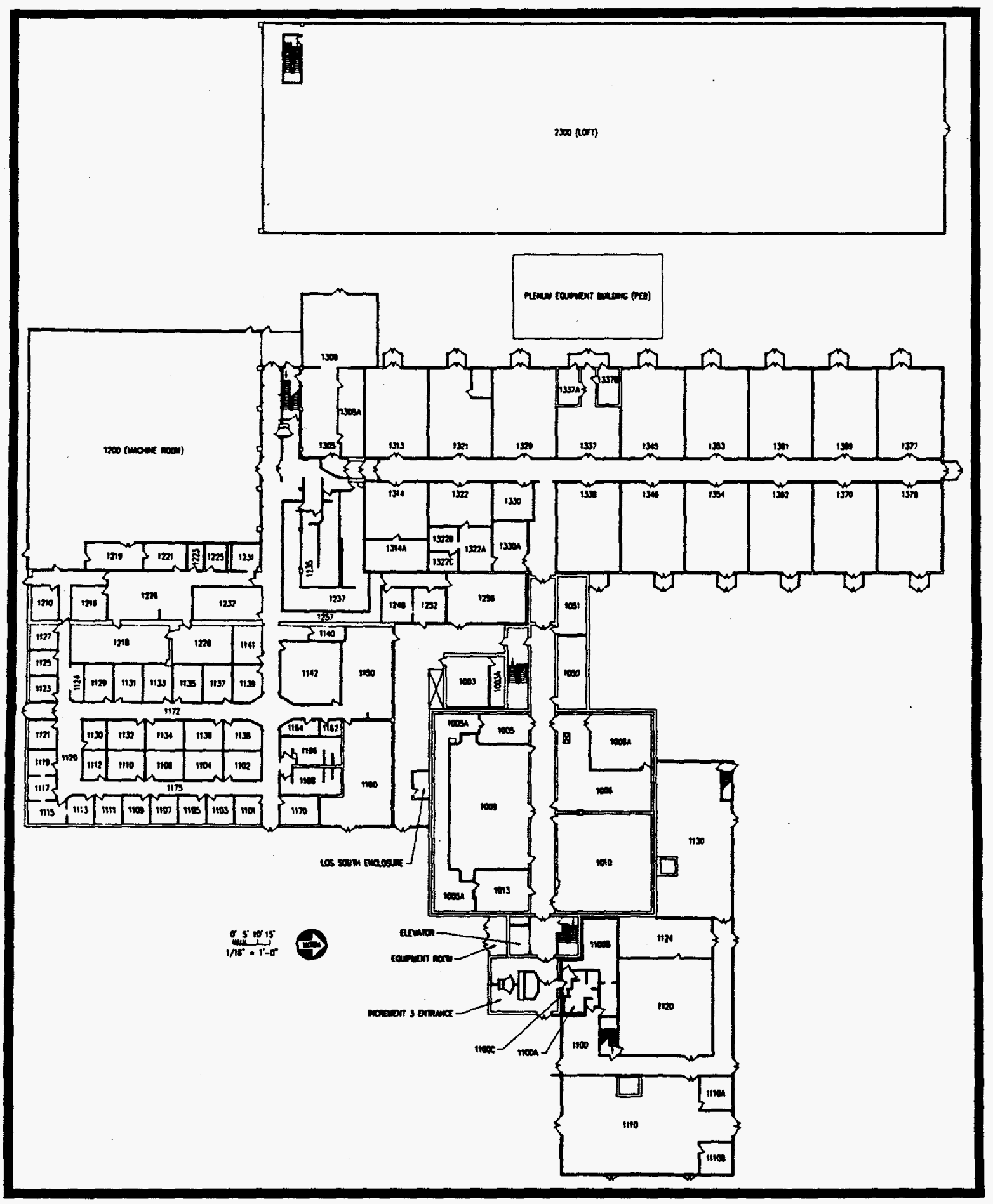

Fig. 7. Floor plan of Building 332. 
and a Hazard Category 2 facility, the effective peak ground acceleration (PGA) of $0.57 \mathrm{~g}$, with a return period of 1,000 years, is listed in Table C-5b of DOE-STD-1020 (DOE 1994c). The effective PGA of $0.57 \mathrm{~g}$ (applying to both horizontal and vertical directions simultaneously is used as the evaluation-based earthquake (EBE).

The facility structure has been analyzed in accordance with design criteria for structural loading from extreme winds. It was found that the seismic design of the facility is more than adequate to protect against severe winds (Degenkolb 1992). Tables 3-1 and 3-2 of DOE-STD-1020 (DOE 1994c) contain current wind design and evaluation criteria for the LLNL Plutonium Facility. The annual probability of exceedance for PC 3 is $1 \times 10^{-3}$, and basic design wind speed is $96 \mathrm{mph}(154 \mathrm{~km} / \mathrm{h})$. Also, DOE-STD-1020 specifies the following minimum missile criteria: 2 - by 4 -in. timber plank; $15 \mathrm{lb}$; velocity (horizontal), $50 \mathrm{mph}$ at a maximum height of $30 \mathrm{ft}$ (aboveground-level).

Increment $1 \mathrm{RMA}$ is a windowless structure, oriented north-south, $\sim 240$ by $87 \mathrm{ft}$, and constructed entirely of reinforced concrete, with 10-in.-thick exterior walls, 8-in.-thick interior walls, and 10.5-in.-thick ceiling (floor to loft). The ground-level floor is an 8-in.-thick concrete slab poured on compacted fill. The walls are supported on continuous spread footings. The ceiling level is $14 \mathrm{ft}$.

The lateral-force-resisting system consists of the laboratory ceiling and the exterior and interior walls. The ceiling transfers lateral loads from the loft area to the exterior and interior walls, where they are transmitted to the foundation. Each laboratory has one exit door leading to the corridor. In most Increment 1 laboratories, another exit leading to the exterior is provided. This exit is designated an emergency exit and consists of two sets of doors. The doors are alarmed for safeguards and security (S\&S) reasons.

Increment $3 \mathrm{RMA}$ is a windowless structure, oriented east-west, $\sim 88$ by $95 \mathrm{ft}$, and constructed entirely of reinforced concrete, with 14-in.-thick exterior walls. The first floor is a 14-in.-thick reinforced concrete slab supported by 8 -in.-thick interior walls, and a 12-in.-thick ceiling. The basement is an 8-in.-thick concrete slab poured on compacted fill. The walls are supported on continuous spread footings. In the spring of 1987, the first-floor slab was modified to permit the installation of the Engineering Demonstration System (EDS) in Room 1009. As part of the new programmatic requirements, the first-floor slab was required to support a concentrated load of $20,400 \mathrm{lb}$, acting at each of two different locations. Two additional pairs of columns were added on new reinforced-concrete footings extending from the basement floor slab. The air-lock connecting Increment 1 and 3 is $\sim 25$ by $57 \mathrm{ft}$.

Room exhaust is collected from each laboratory in Increment 1 via a duct network housed in the mechanical loft on the second floor of the increment. From there, exhaust air is sent to the PEB via a single overhead duct. The PEB is located along the west wall of the increment and contains the filter plenum and exhaust fans. The incoming overhead duct is split into two ducts. Each duct enters an airtight steel compartment (HEPA filter plenum). Each compartment of the HEPA filter plenum is furnished with its own serially placed fire-suppression deluge sprinklers, demister, and two in-series HEPA filter stages. For each compartment, differential-pressure gauges are installed for each stage and also for both filter stages.

The Increment 3 room exhaust collection subsystem is functionally identical to that described for Increment 1 . The room-exhaust subsystem collects the air supplied to each laboratory via two to four room exhaust ducts. Each exhaust collection point is provided with a prefilter and $95 \%$ efficiency filter. Exhaust flow is drawn downward into the basement through an exhaust-collection duct network. Air from the basement area is drawn into the same room exhaust-collection duct work. The exhaust ducting is split into two delivery ducts prior to entering an airtight HEPA filter plenum with two compartments. Each compartment contains a water spray system for fire protection of the HEPA filters, a demister, and two serially placed HEPA filter stages. Each filter stage is provided with pressure-differential gauges. There is also a gauge that measures the pressure across both stages.

Building 332 currently contains the following processes that support the current programmatic missions of the facility:

- receiving, storage, and shipping of Category I quantities of SNM;

- SNM control and accountability activities;

- transfer of plutonium and fissile uranium within the RMA;

- plutonium and fissile uranium operations and experiments;

- plutonium analytical chemistry and metallography; and

- scrap recovery and waste processing. 
For plutonium oxide receiving and storage, existing capability in Building 332 would be used. The Material Management laboratory is used to receive, inspect, temporarily store, package, radio assay, and prepare canned SNM for Department of Transportation shipments. It is also used as a staging area to segregate and disseminate packages of canned SNM needed for Plutonium Facility operations. Cans containing SNM are counted in a confirmatory measurement counter (CMC) before shipment. Components of the CMC are a MicroVAX computer, a video display terminal, a printer, a counting chamber, and a JSR-11 Neutron Coincidence Counter. Existing vaults would be used for storage of plutonium oxide feed. Existing nondestructive assay (NDA) equipment could be used to determine mass amounts of SNM. Equipment currently includes four heat calorimeters, two gamma-ray spectroscopy units, one segmented gamma scanner, three calorimeter preheater units, and two short-term SNM storage lockers. However, additional NDA equipment may be required to support an LTA mission.

For MOX rod processing, a laboratory in Increment 3 would be used (Rooms 1005, 1005A, 1009, and 1013). This laboratory is a $40-\mathrm{ft}$ by $80-\mathrm{ft}$ room $\left(3200 \mathrm{ft}^{2}\right)$ that contains glove boxes that have never been contaminated. Modifications to this laboratory would involve removing these glove boxes, removing the "soft" (Sheetrock ${ }^{\mathrm{TM}}$ ) walls, and making minor modifications to the room ventilation system.

\subsubsection{Building 334}

Building 334 is a $9900-\mathrm{ft}^{2}$, windowless, three-story, reinforced-concrete building that contains two 28-ft-high bays, a control room for each bay, two restrooms, a lobby/stairwell, an amplifier equipment room, and a mechanical equipment room. The building is $\sim 90 \mathrm{ft}$ wide by $70 \mathrm{ft}$ deep. The first $3.8 \mathrm{~m}$ of the aboveground walls are $30 \mathrm{~cm}$ thick with two curtains of 5/8-in. steel bars, each forming a lattice of $30-\mathrm{cm}$ squares staggered to form a 15-cm pattern. Both interior and exterior walls above $3.8 \mathrm{~m}$, as well as the roof slabs, are 20-cm-thick concrete, reinforced with a single curtain of $5 / 8$-in. rebars placed to form a single $15-\mathrm{cm}$ grid pattern. All wall penetrations greater than $620 \mathrm{~cm}^{2}$, such as air intakes and exhaust, are barricaded with $5 / 8$-in. rebars in a 15 -cm grid.

There are two distinct parts of this facility. The Engineering Test Bay (ETB) is located on the east side of the building and is associated with the first-floor control room. The ETB is used to conduct thermal and dynamic tests on weapons components. The Radiation Measurements Facility is used to make intrinsic radiation measurements of various components. The facility is in the Intrinsic Radiation (INRAD) Bay, which is on the west side of the building and is associated with the second-floor control room. Figures 8,9 , and 10 show the floor plans of the facility. This facility is within the LLNL Superblock and can handle Category I quantities of encapsulated SNM.

For fuel rod bundling, fuel bundle storage, and fuel bundle packaging and shipping, the ETB of Building 334 would be used. This bay is about $40 \mathrm{ft}$ by $50 \mathrm{ft}$. The equipment in this bay would be moved to accommodate the LTA mission. The hardened exterior doors on the east are $12 \mathrm{ft}$ wide by $12 \mathrm{ft}$ high.

The structural framing system for Building 334 was designed to LLNL Moderate Hazard criteria for earthquake considerations. Additionally, the exterior walls of the building have been designed to meet LLNL security requirements with respect to "hardening" against forced penetration. Supporting calculations and drawings are on file and available for review. The structural framing criteria for Building 334 for earthquake criteria are as follows: (1) design for a design-basis earthquake (DBE) with a $0.25 \mathrm{~g}$ horizontal PGA acting simultaneously using UBC material strength allowable. Building connections shall be designed for an additional load factor of 1.5 times the earthquake forces resulting from the $0.25 \mathrm{~g} \mathrm{DBE}$ (horizontal plus vertical); (2) design for DBE with a $0.50 \mathrm{~g}$ horizontal PGA applied simultaneously with a vertical PGA of $\pm 0.33 \mathrm{~g}$. For this level of $\mathrm{DBE}$, the building structure must remain intact during and after the earthquake.

The release of radioactive materials into Building 334 is prevented through SNM containment and adherence to Operational Safety Requirements (OSRs). The release of radioactive material from Building 334 is prevented using primary and secondary confinement barriers. The bays (INRAD and ETB) provide confinement. Walls and equipment enclosures (such as a thermal chamber) provide physical barriers; the bay ventilation systems provide a dynamic barrier. (Each bay has an independent ventilation system.) If radioactive materials leak into the bays, they would be confined within the building by the ventilation system. This system recirculates each bay's air through two stages of HEPA filters before returning $90 \%$ back to the bay and exhausting $10 \%$ to the outside. The bays are kept at -0.02 -in. water static pressure with 


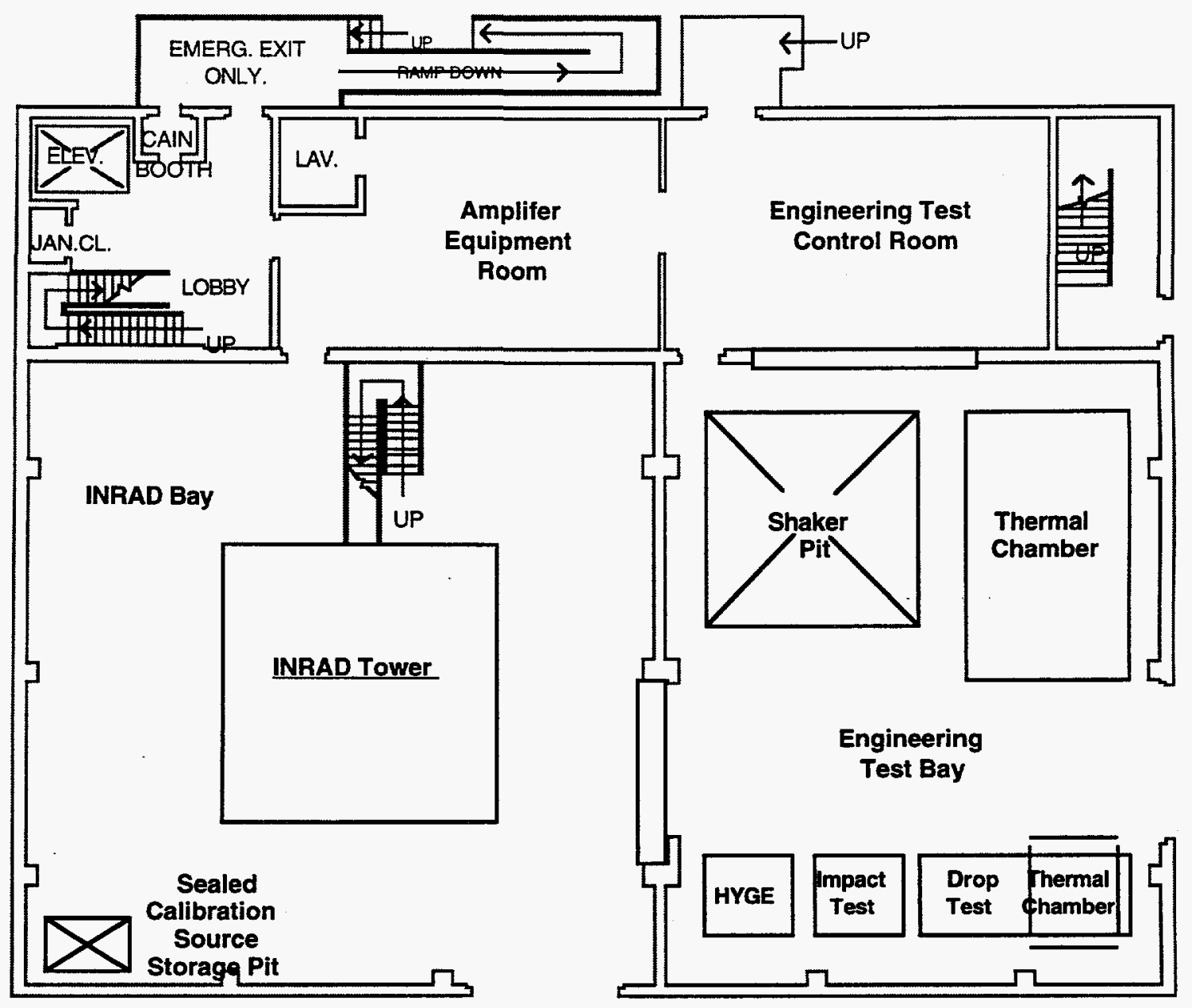

Fig. 8. First-floor plan of Building 334. 


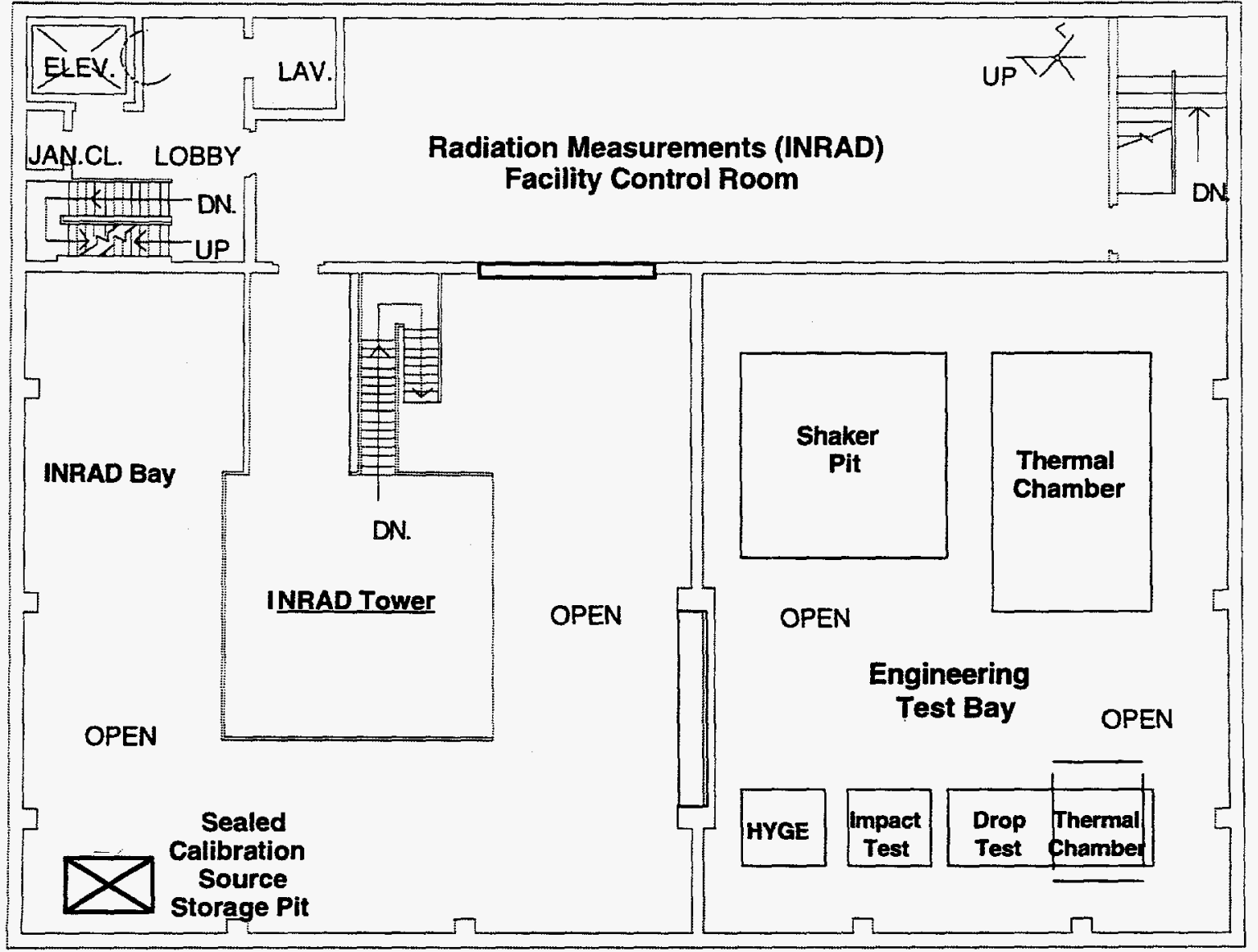

Fig. 9. Second-floor plan of Building 334 . 


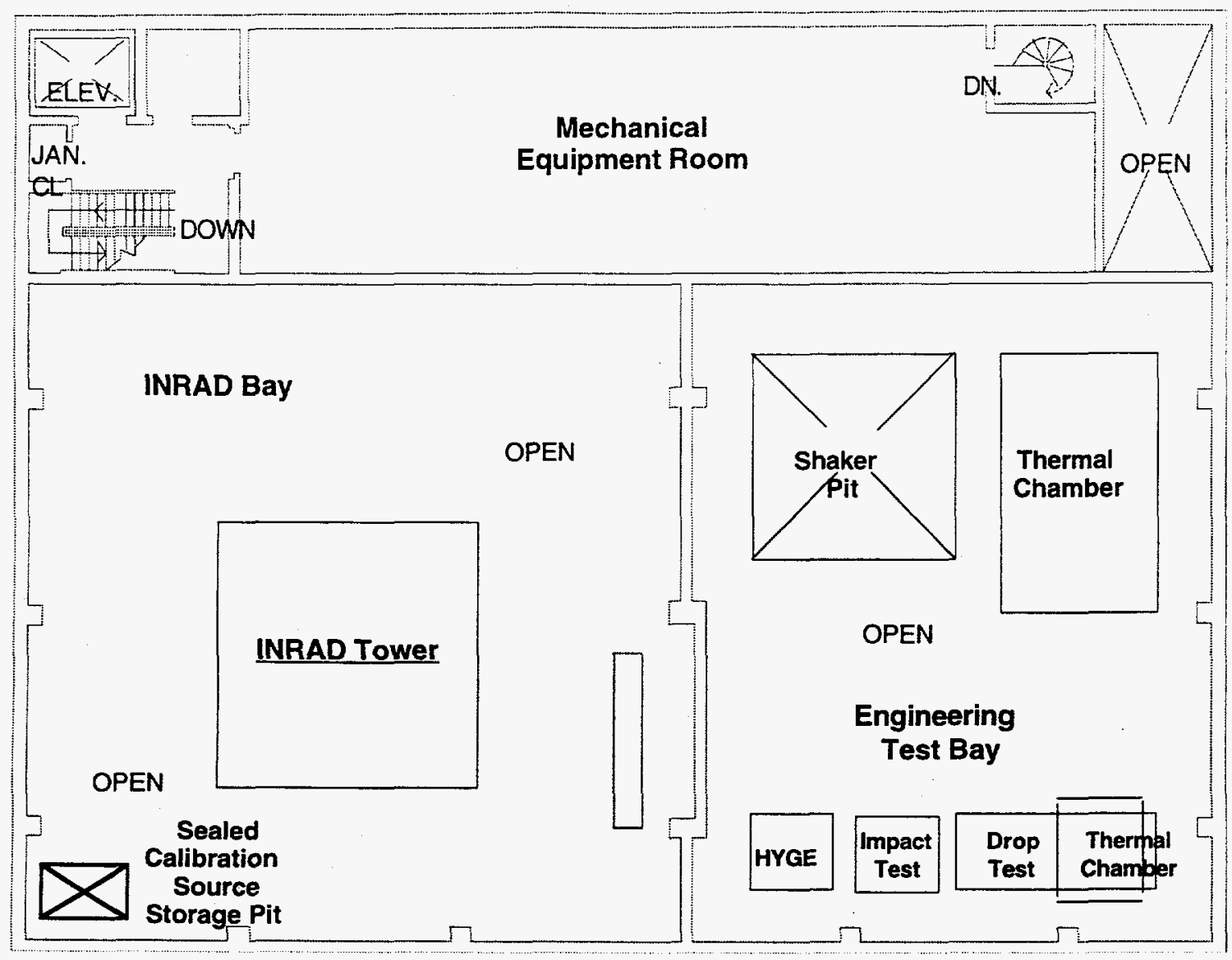

Fig. 10. Third-floor plan of Building 334.

respect to the outside and the rest of the building, causing air to flow toward areas of potential contamination.

\subsubsection{Building 335}

Building 335 is a "cold" facility adjacent to the northeast corner of Increment III of Building 332 in the LLNL Superblock. This $12,270-\mathrm{ft}^{2}$ steel-frame, concrete-foundation building was constructed in 1985 to support the Special Isotope Separation Program. Approximately one-half of the facility $\left(6000 \mathrm{ft}^{2}\right)$ consists of a high bay with $\sim 25 \mathrm{ft}$ of vertical clearance and a bridge crane traversing the full length of the high bay. This high bay is currently used for equipment assembly, training, and technician work space. The facility also houses an alternate portal area for accessing the radioactive materials area (RMA) of Building 332. This portal area, which would be used to provide access to LTA work, consists of lobby, change rooms, bathroom facilities with showers, security booths, and portal safeguard monitors. The remainder of the facility is currently used for equipment and records storage, as well as office space. Building 335 would be used by the LTA project for assembly and testing of equipment before it is moved into the RMA, for storage of spare parts and supplies, and as a work area for electrical and mechanical technicians supporting the project. No other program commitments for the facility would preclude its use by the LA project.

\subsection{SUPPORT LABORATORIES}

Support laboratories for an LTA mission include the analytical and metallography laboratories and the scrap recovery and waste processing laboratory and their equipment. 


\subsubsection{Scanning Electron Microscope and X-Ray Analysis Laboratory (Room 1313)}

This laboratory provides for X-ray spectrometric (chemical) and X-ray diffraction (structural) analyses of plutonium and other materials. Various X-ray spectrometers and diffraction instruments are used in this work. Room 1313A, which is within Room 1313, contains a scanning electron microscope (SEM).

Samples examined in the SEM are first cleaned in the ultrasonic cleaner in Room 1322 and then transferred in stainless steel cans to Room 1313B, where they are loaded into the SEM and analyzed.

A diagnostic tool (diamond cell) is used in this room to obtain static high-pressure data on less-thanmilligram quantities of plutonium and other actinide elements. A differential scanning calorimeter, which is used to perform thermal analyses on samples containing milligram quantities of plutonium and plutoniumbearing materials, is also in this laboratory.

Other work conducted in this laboratory includes sectioning samples containing plutonium with a diamond saw and torch-sealing sample capillary tubes.

\subsubsection{Analytical Chemistry Laboratory (Rooms 1321 and 1321A)}

Workstations in this laboratory are used for preparing and analyzing plutonium-based samples or other actinides, alloy metals, and impurities. This laboratory has an open-front hood that is used for opening cans containing actinide samples transferred from the vault.

Preparation of nonradioactive samples, standards, and very-low-activity alpha assay samples are also carried out in this hood.

Glove box work activities include sample dissolution, chemical separations, and oxidation of plutonium metal. Emission spectroscopy is also performed.

The direct current (dc) plasma spectrometer is used to determine trace quantities of impurities in plutonium samples.

Room 1321A contains alpha- and gamma-radiation counting equipment.

\subsubsection{Metallography Laboratory (Room 1322)}

This laboratory provides the capability to conduct microstructural analyses of metals, alloys, and compounds in support of programmatic requirements. Operations in this laboratory include sample preparation of "cold" and radioactive materials, encapsulating, cleaning, electropolishing, microhardness testing, photomicrography, and photographic processing. Specimens are then archived or unencapsulated for SNM recovery.

\subsubsection{Analytical Chemistry Laboratory (Room 1329)}

This laboratory is used for cutting and sorting actinide (primarily plutonium) samples and preparing them for gamma-ray spectroscopy, mass spectroscopy; emission spectroscopy, gas analysis, and plasma spectrometry. In addition to glove boxes, this room has an open-front hood used for opening cans that contain materials transferred from the vault or other laboratories. Preparation of nonradioactive samples, standards, and very-low-activity alpha assay samples is also carried out in the hoods.

This laboratory contains three nitrogen-atmosphere glove boxes that are used for cutting, sorting, and weighing. Dissolution and chemical separation of samples are performed in Workstation 2903 (wet chemistry analytical line). A caustic wet scrubber is attached to this workstation to remove acid fumes from the glove box exhaust.

Two air-atmosphere glove boxes in this laboratory contain gas analyzers for determining the carbon, sulfur, nitrogen, oxygen, and hydrogen content in samples of metals, powders, and salts.

\subsubsection{Microprobe Laboratory and Sputtering Facility (Rooms 1330 and 1330A)}

Room 1330 contains a sputtering facility and a sputtering shield cleaning facility. These facilities, which produce materials needed for research, provide a high-rate sputtering source for projects requiring the deposition of thin films. The process uses a triode sputtering system, which is capable of sputtering any 
metallic element or alloy, and can safely sputter materials bearing alpha activity. This sputtering system is enclosed in a vacuum chamber that is located inside a glove box.

The cleaning facility provides a means of removing residual films after chemical dissolution of plutonium and other sputtered metals have been deposited on the shields. Removal of films, by glass-bead blasting and ultrasonic cleaning, is required before the shields can be reused in the sputtering chamber. This work is conducted inside glove boxes.

Room 1330A provides a location for X-ray microanalysis of plutonium and plutonium alloys. These analyses are used in conjunction with optical metallography to characterize materials. This work includes the preparation of samples in a carbon evaporator and the observation and recording of the composition and topography of plutonium and plutonium-based materials in the electron microprobe.

Samples for these analyses are first cleaned in the ultrasonic cleaner located in Room 1322 and then transferred to this laboratory for microprobe examination.

\subsubsection{Inspection Laboratory (Room 1362)}

This room contains equipment in glove boxes that is used to make precision measurements and inspections on plutonium-bearing parts to verify that they meet design specifications. Approximately $90 \%$ of the work is performed on classified parts in this room.

The following equipment is contained within individual glove boxes:

- Sheffield Rotary Contour Gauges--Two of these gauges are contained in one glove box and are used to inspect the radii and wall thicknesses of parts. One of the gauges is computer controlled, while the other is manually controlled.

- Moore Measuring Machine-This equipment can be used as a radius gauge to measure spherical parts, as a surface analyzer to measure surface finishes of machined parts, and to inspect diameters of plutonium spheres by the point-to-point method.

- Surface Plate-With a precision flat granite base, this glove box contains precision tools and gauges used to inspect plutonium parts. Machined parts are checked for heights, diameters, and positional accuracy of steps or drilled holes using height gauges, gauge blocks, micrometers, or calipers.

- Surface Analyzer-A Class II laser, mounted on a precision flat granite base, is used to inspect surface finishes of machined plutonium parts. These parts are inspected for roughness average and profile of curved and flat surfaces.

- Balance Box-Electronic balances in this box are used to weigh plutonium parts for programmatic inventory control in the range of a few grams to about $5 \mathrm{~kg}$.

\subsubsection{Physical Testing Laboratory (Room 1369)}

In this laboratory, plutonium, plutonium-alloy, and nonradioactive metal samples are prepared in glove boxes for metallographic and chemical analysis. High-temperature, torsion, tension, and compression testing are also conducted in this laboratory. Compatibility testing is performed by melting plutonium or uranium in a crucible and then immersing a metal sample into the molten metal bath. After a prescribed period of time, samples are withdrawn and examined for degradation of the original properties of the sample metal. An electropolisher, ultrasonic cleaner, low-speed diamond saw, and various hand tools are used to prepare samples for testing. Penetrant-dye testing for cracks, macro photo documentation, and precision density determinations are also performed.

\subsubsection{Plutonium Recovery and Waste Handling Laboratory (Room 1378)}

Plutonium solid and liquid waste processing and plutonium recovery operations are conducted in this laboratory. These operations include sorting and calcining solids to produce ash containing $\sim 50 \% \mathrm{PuO}_{2}$. Treatment of liquid wastes includes leaching and precipitation of plutonium from aqueous process wastes and solidification of the supernatant liquid with cement before packaging for shipment. Plutoniumcontaminated liquid organic wastes, such as oils, are solidified in the cement mixture before packaging for shipment. 
Page Intentionally Blank 


\section{PROCESS DESCRIPTIONS}

\subsection{PROCESS FLOW DIAGRAM}

A process block flow diagram is provided in Fig. 11. Assumptions for the process were given in Table 4. Figure 11 provides the total quantity of HM throughput that is anticipated at each step of the process for an entire year of operations after the facility reaches steady state.

To achieve a state of reliable operations for the new facility, cold startup and hot startup phases are anticipated to be necessary. Table 5 provides the anticipated material requirements for each phase of the startup and operations for the LA MOX fuel fabrication facility. The cold startup consists of using only depleted $\mathrm{UO}_{2}$ in the fuel fabrication process to develop acceptable processing steps.

Hot startup consists of using the final MOX fuel blend to determine that each processing step meets acceptable standards of fuel quality and repeatability.

\subsection{WASTE MANAGEMENT FLOW DIAGRAMS}

Figure $12(a)$ and $(b)$ are simplified flow diagrams that indicate how all forms of waste from the LA MOX fuel fabrication facility will be handled and disposed. These flow diagrams are generic examples of how waste will be handled for each site. Of course, each site will have some site-specific variations from the given flow diagrams, but for the purposes of this study the given material flow diagrams should be adequate.

For LLNL, liquid LLW will be treated at the Hazardous Waste Management Facility; solid LLW will then be stored at the Hazardous Waste Management Facility before being disposed of off-site at the Nevada Test Site. TRU waste will be stored at the Hazardous Waste Management Facility while awaiting final disposal at the Waste Isolation Pilot Plant (WIPP). 


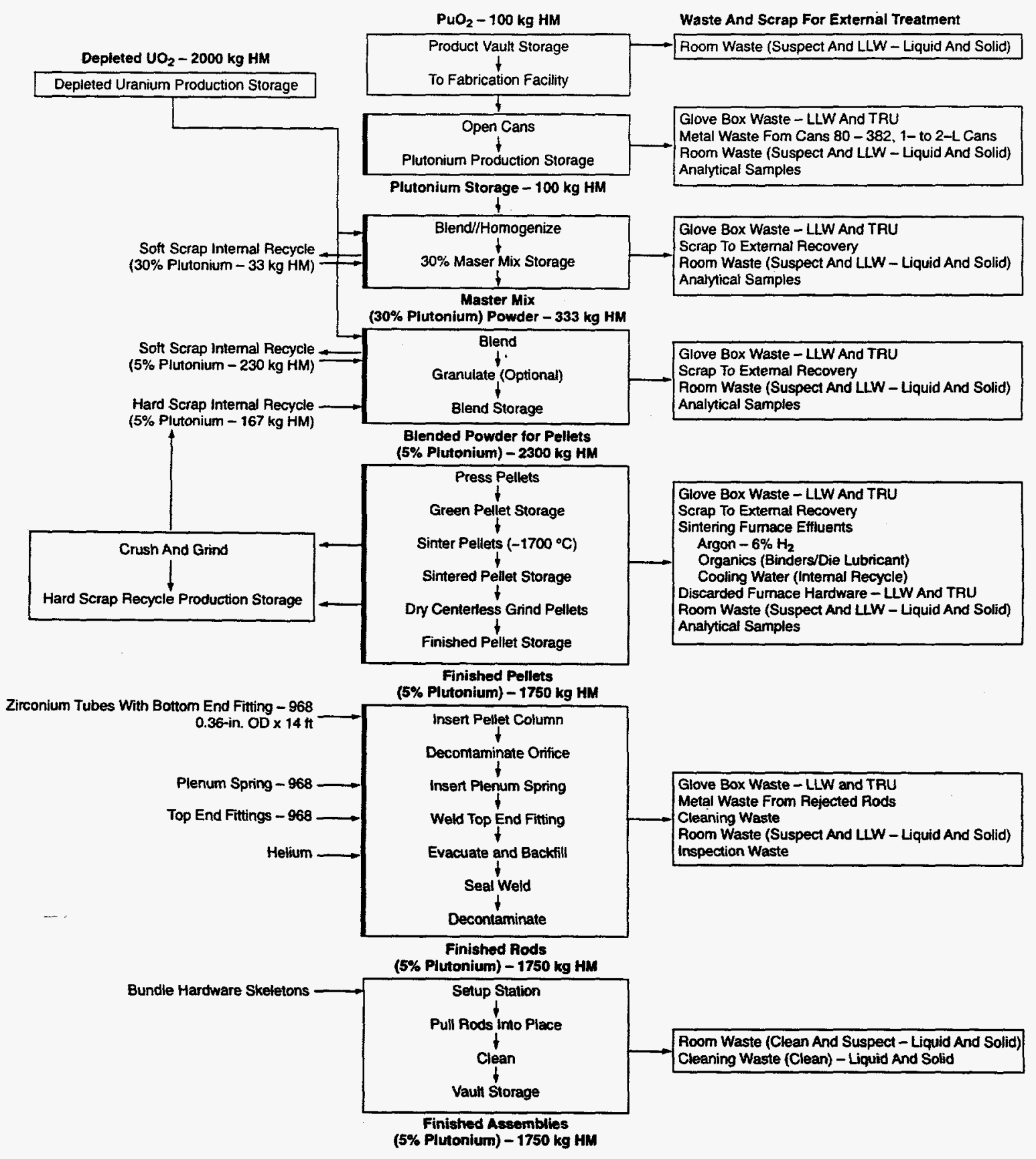

Note: 1 . Heavy borders are glove box process operations.

2. A total of $20 \%$ of pellets will be recycled.

Fig. 11. LA MOX fuel flow sheet outline with annual throughputs. 
Table 5. LA MOX fuel fabrication requirements

\begin{tabular}{|c|c|c|c|c|c|c|c|c|c|c|}
\hline & \multirow[b]{2}{*}{ Units/bundle } & \multicolumn{2}{|c|}{ Product produced $^{a}$} & \multirow[b]{2}{*}{$\begin{array}{l}\text { Cold } \\
\text { startup }\end{array}$} & \multirow[b]{2}{*}{$\begin{array}{l}\text { Hot startup } \\
\text { (6 months) }\end{array}$} & \multicolumn{4}{|c|}{ Production capacity required ${ }^{a}$} & \multirow[b]{2}{*}{ Total } \\
\hline & & $\begin{array}{l}\text { Output- } \\
3 \text { years }\end{array}$ & $\begin{array}{l}\text { Output- } \\
1 \text { year }\end{array}$ & & & $\begin{array}{l}\text { Rejection } \\
\text { rate }^{b}\end{array}$ & $\begin{array}{c}\text { Capacity/ } \\
3 \text { years }\end{array}$ & $\begin{array}{l}\text { Capacity/ } \\
1 \text { year }\end{array}$ & $\begin{array}{c}\text { Capacity/d } \\
(200 \mathrm{~d} / \text { year })\end{array}$ & \\
\hline \multicolumn{11}{|l|}{ Base requirements and assumptions } \\
\hline Bundles/year [pressurized-water reactor (PWR) $17 \times 17$ ] & & 10 & 3 & & & $0 \%$ & 10 & 3.3 & & 10 \\
\hline Rods & 264 & 2,640 & 880 & 220 & 220 & $10 \%$ & 2,904 & 968 & 5 & 3,344 \\
\hline Pellets $(0.327$-in. diam $\times 0.4$ in. $\times 14 \mathrm{ft})$ & 110,880 & $1,108,800$ & 369,600 & 110,880 & 110,880 & $20 \%$ & $1,330,560$ & 443,520 & 2,218 & $1,552,320$ \\
\hline \multicolumn{11}{|l|}{ Plutonium and depleted uranium required } \\
\hline Plutonium ( $5 \%$ in depleted uranium), $\mathrm{kg} \mathrm{HM}^{\mathrm{C}}$ & 25 & 250 & 83 & & 21 & $20 \%$ & 300 & 100 & 0.5 & 321 \\
\hline Depleted uranium, $\mathrm{kg} \mathrm{HM}$ & 500 & 5,000 & 1,667 & 450 & 417 & $20 \%$ & 6,000 & 2,000 & 10 & 6,867 \\
\hline Total plutonium + depleted uranium, $\mathrm{kg} \mathrm{HM}^{\mathrm{C}}$ & 525 & 5,250 & 1,750 & 450 & 438 & $20 \%$ & 6,300 & 2,100 & 11 & 7,188 \\
\hline \multicolumn{11}{|l|}{ Scrap generation } \\
\hline Total scrap depleted uranium, kg HM & & & & 450 & & & & & & $450^{d}$ \\
\hline $\begin{array}{l}\text { Total scrap plutonium (mixed with depleted uranium), } \\
\mathrm{kg} \mathrm{HM}\end{array}$ & & & & & 13 & & 51 & 17 & 0.1 & $64^{d}$ \\
\hline $\begin{array}{l}\text { Total scrap depleted uranium (mixed with plutonium) } \\
\mathrm{kg} \mathrm{HM}\end{array}$ & & & & & 250 & & 1,000 & 333 & 2 & 1,250 \\
\hline \multicolumn{11}{|l|}{ Recycle and recovery scrap and waste quantities } \\
\hline $\begin{array}{l}\text { Recycled hard scrap } e^{2} \text { (mixed with depleted uranium) } \\
\text { kg HM }\end{array}$ & & & & & 6.25 & & 25 & 8 & & 31 \\
\hline $\begin{array}{l}\text { Recycled hard scrap depleted uranium (mixed witl } \\
\text { plutonium), kg HM }\end{array}$ & & & & & 125 & & 500 & 167 & & 625 \\
\hline $\begin{array}{l}\text { Scrap plutonium to recovery (mixed with depletec } \\
\text { uranium), kg HM }\end{array}$ & & & & & 5 & & 21 & 7 & & 26 \\
\hline $\begin{array}{l}\text { Scrap depleted uranium to recovery (mixed with } \\
\text { plutonium), kg HM }\end{array}$ & & & & & 100 & & 400 & 133 & & 500 \\
\hline Waste plutonium $f$ (mixed with depleted uranium), $\mathrm{kg} \mathrm{HM}$ & & & & & 1.25 & & 6 & 2 & & 7 \\
\hline Waste depleted uranium (mixed with plutonium), $\mathrm{kg} \mathrm{HM}$ & & & & & 25 & & 100 & 33 & & 125 \\
\hline \multicolumn{11}{|l|}{ Waste volumes } \\
\hline Volume of transuranic (TRU) waste generated, ${ }^{g} \mathrm{~m}^{3}$ & & & & & 10 & & 120 & 40 & 0.2 & 130 \\
\hline Volume of low-level waste (LLW) generated, $\mathrm{m}^{3}$ & & & & 10 & 10 & & 120 & 40 & 0.2 & 140 \\
\hline Volume of mixed LLW generated, $\mathrm{m}^{3}$ & & & & 0.4 & 0.4 & & 3 & 1 & & 4 \\
\hline Volume of liquid LLW generated, L & & & & 40,000 & 40,000 & & 480,000 & 160,000 & 800 & 560,000 \\
\hline Volume of liquid TRU generated, $\mathrm{L}$ & & & & & 50 & & 600 & 200 & 1 & 650 \\
\hline Volume of nonhazardous solid, $\mathrm{m}^{3}$ & & & & 650 & 650 & & 3,900 & 1,300 & & 5,200 \\
\hline Volume of nonhazardous sanitary liquid, $\mathrm{L}$ & & & & 800,000 & 800,000 & & $4,800,000$ & $1,600,000$ & & $6,400,000$ \\
\hline
\end{tabular}

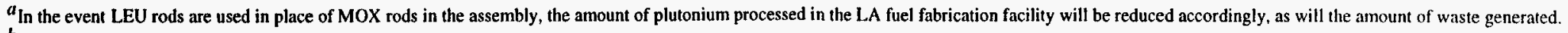

${ }^{b}$ Assumed that pellets in rejected rods can be reused.

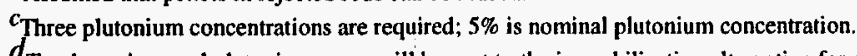

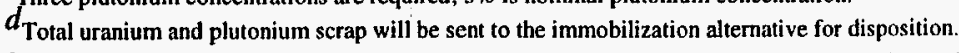

${ }^{{ }}$Hard scrap is from centerless grinding of pellets and rejected sintered pellets; $50 \%$ of hard scrap is assumed to be recycled. Soft scrap, consisting of off-specification powder blends, will be recycled within process line and is not considered in this table.

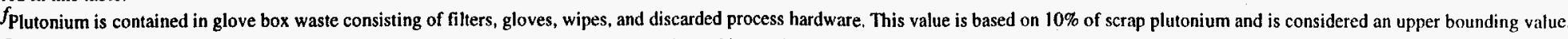

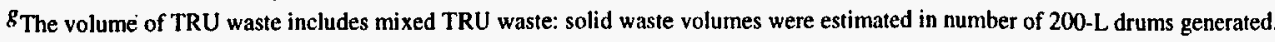


ORNL-DWG 97-2856 EFG

Nonprocess Liquid Waste (Aqueous)

Sanitary Waste From All Facilities

Spent Cooling Water From Facilities

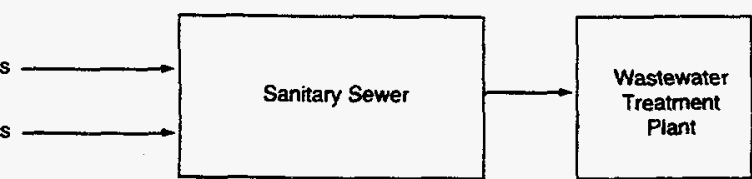

Nonprocess Solid Waste

Room Trash, Garbage, And Similar Solid Waste

Send to Landfill (On-Or OH-site)

\section{Liquid Radioactive Waste}

Liquid Low-Level Radioactive Waste (LUW)

LUW Processing (1)

Solid Radioactive Waste

Radioactive Solid Waste (2)

Solid Low-Level Radioactive Waste (LLW) LLW Processing (3)

Transuranium Waste (TRU) $>100 \mathrm{nCi} / \mathrm{g}$

ThU Processing (4)

TRU Mixed With RCRA Hazardous Chemical Waste (TRUMW)

TRUMW Processing (5)

LLW Mixed With RCRA Hazardous Chemical Waste (LLMW)

LLMW Processing (6)

RCRA Hazardous Chemical Waste

Package And Send To DOE Or Off-Site

RCRA Treatment, Storage, And/Or Disposal Facitty (TSDF)

Fig. 12(a). Waste generated during LA MOX fuel fabrication facility operation. 
1. LLLW Processing

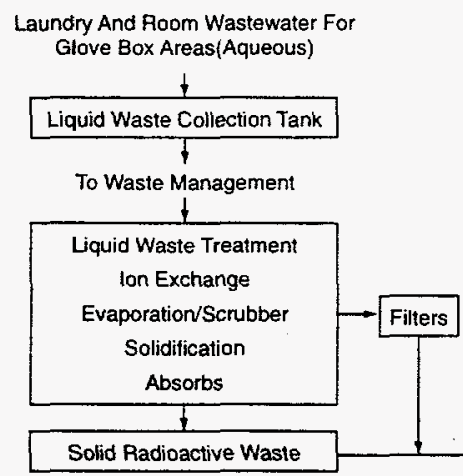

3. LW Processing

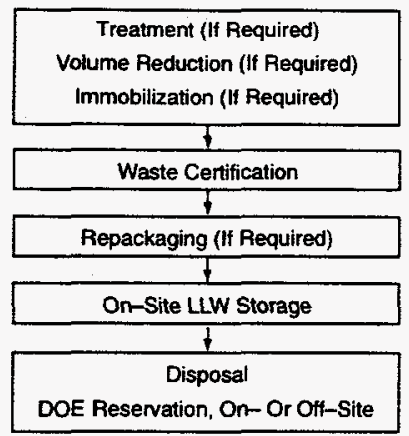

2. Solid Radioactive Waste

Glove Box And Some Foom Waste

\begin{tabular}{|c|c|}
\hline Segregation By Generator & Hazardous Mixed Waste \\
\hline Compactable & \pm \\
\hline Noncompactable & Collection By Generator \\
\hline Special Case Waste & 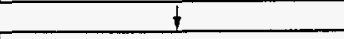 \\
\hline 1 & Packaging By Generator \\
\hline Collection By Generator & 1 \\
\hline 1 & Certification By Generator \\
\hline Packaging By Generator & t \\
\hline 1 & ACRA 90-d Storage \\
\hline Certification By Generator & \\
\hline To Waste Management & To Waste Management \\
\hline 1 & + \\
\hline $\begin{array}{c}\text { Nondestructive Assay } \\
<100 \mathrm{nCi} / \mathrm{g} \text { To LLW Processing } \\
>100 \mathrm{nCV} g \text { To TRU Processing }\end{array}$ & $\begin{array}{c}\text { Nondestructive Assay } \\
<100 \mathrm{nCl} / \mathrm{g} \text { To LLMW Processing } \\
>100 \mathrm{nCi} / \mathrm{g} \text { To TRUMW Processing }\end{array}$ \\
\hline
\end{tabular}

6. LLMW Processing

\begin{tabular}{|c|}
\hline RCRA Storage \\
\hline Treatment (If Required) \\
Immobilization (II Required) \\
\hline Package \\
\hline Disposal \\
RCRA Approved, On-Or OH-Site \\
\hline
\end{tabular}

4. TRU Solid Waste >100 nCi/g Processing

5. TRUMW Processing

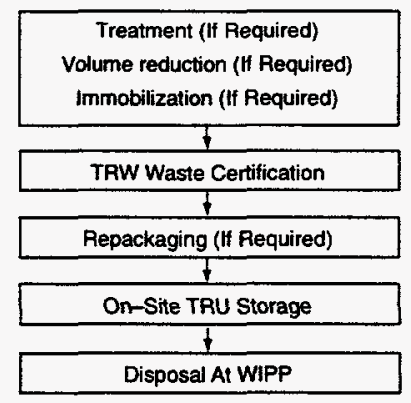

Fig. 12(b). Waste generated during LA MOX fuel fabrication facility operation. 



\section{RESOURCE NEEDS}

\subsection{CONSTRUCTION RESOURCE NEEDS}

The LA program at LLNL would utilize existing laboratories in Buildings 332,334 , and 335 , and no new building construction would be required. Existing laboratories would be modified, as necessary, and any existing equipment in those laboratories would be removed and used elsewhere at LLNL. The laboratories currently identified for this program contain "clean equipment," which would be moved before modification of these areas. Therefore, there are no significant, sensitive, or unusual resource requirements that would be needed during modification of this identified space.

\subsection{OPERATIONAL RESOURCE NEEDS}

The initial scaling factor for resource requirements for the LA fabrication facility is based on a linear measure derived from the capacity of the MOX fuel fabrication facility. The annual quantity of surplus plutonium [3.5 metric tons (MT) plutonium (4.0 $\mathrm{MT} \mathrm{PuO}_{2}$ )] and the MOX fuel fabrication facility requirements were obtained from the LANL Response to the Surplus Plutonium Disposition Environmental Impact Statement Data Call for a Mixed Oxide Fuel Fabrication Facility Located at the Pantex Plant. ${ }^{1}$ The annual quantity requirement for uranium [88 MT HM (100 MT UO 2$)$ ] was obtained from the Initial Data Report and Response to the Surplus Plutonium Disposition Environmental Impact Statement Data Call for the $\mathrm{UO}_{2}$ Supply. ${ }^{2}$ follows:

The annual plutonium and uranium capacity requirements and the scaling factors are calculated as

1. LA fabrication facility plutonium capacity

Plutonium required for production $=250 \mathrm{~kg} \mathrm{HM}$ plutonium

Plutonium required including rejection rate of $20 \%=250 \mathrm{~kg} \mathrm{HM}$ plutonium $\times 120 \%=300 \mathrm{~kg} \mathrm{HM}$ plutonium (50 $\mathrm{kg} \mathrm{HM}$ to be recycled)

Annualized plutonium requirements $=(300 \mathrm{~kg} \mathrm{HM}$ plutonium $) / 3$ years $=100 \mathrm{~kg} \mathrm{HM}$ plutonium

Annualized MT HM plutonium capacity $=(100 \mathrm{~kg} \mathrm{HM}$ plutonium $) /(1000 \mathrm{~kg} / \mathrm{MT})=0.1 \mathrm{MT} \mathrm{HM}$ plutonium

2. LA fabrication facility uranium capacity

Uranium required for production $=5000 \mathrm{~kg} \mathrm{HM}$ uranium

Uranium required including rejection rate of $20 \%=5000 \mathrm{~kg} \mathrm{HM}$ uranium $\times 120 \%=6000 \mathrm{~kg} \mathrm{HM}$ uranium ( $1000 \mathrm{~kg} \mathrm{HM}$ to be recycled)

Annualized uranium requirements $=(6000 \mathrm{~kg} \mathrm{HM}$ uranium $) / 3$ years $=2000 \mathrm{~kg} \mathrm{HM}$ uranium

Annualized MT HM uranium capacity $=(2000 \mathrm{~kg} \mathrm{HM}$ uranium $) /(1000 \mathrm{~kg} / \mathrm{MT})=2.0 \mathrm{MT}$ HM uranium

3. LA fabrication facility capacity

Annual LA capacity $=(0.1$ plutonium +2.0 uranium $)$ MT HM $=2.1 \mathrm{MT}$ HM MOX

Annual mission surplus plutonium $=3.5 \mathrm{MT}$ HM plutonium

Annual uranium requirements for mission $\mathrm{MOX}$ at 5\% plutonium $=66.5 \mathrm{MT} \mathrm{HM}$ uranium

Annual MOX production $=(3.5$ plutonium +66.5 uranium $)$ MT HM MOX $=70$ MT HM MOX

4. Scaling factor $=(2.1 / 70) \mathrm{MT} \mathrm{HM} \mathrm{MOX}=0.03 \%=3 \%$

This report assumes that $3 \%$ of the MOX fuel fabrication facility requirements is the initial base requirement of the LA fabrication facility. Resource requirements and contingencies in addition to $3 \%$ are noted separately for each resource. In situations where requirement scaling is not applicable, full calculations of resource requirements are provided. Resources needed for the LA fabrication facility are summarized in Table 6. (In the event LEU rods are used in place of some MOX rods, the resource needs will be reduced proportionately.) 
Table 6. Resource needs during operation of the LA fabrication facility

\begin{tabular}{|c|c|}
\hline Resource requirement & Annual average consumption \\
\hline \multicolumn{2}{|l|}{ Utilities } \\
\hline Electricity & $720 \mathrm{MWh}$ \\
\hline Peak demand & $<300 \mathrm{~kW}(\mathrm{e})$ \\
\hline \multicolumn{2}{|l|}{ Fuel } \\
\hline Natural gas (for heating) & $55,200 \mathrm{~m}^{3}\left(1,950,000 \mathrm{ft}^{3}\right)$ \\
\hline Oil products (for generator) & $4,600 \mathrm{~L}(1,200 \mathrm{gal})$ \\
\hline Gasoline (for vehicles) & $6,900 \mathrm{~L}(1,825 \mathrm{gal})$ \\
\hline \multicolumn{2}{|l|}{ Water } \\
\hline Surface water & $1,600,000 \mathrm{~L}(411,000 \mathrm{gal})$ \\
\hline Peak demand & No peak requirements anticipated \\
\hline Groundwater & None required \\
\hline \multicolumn{2}{|l|}{ Process chemicals and compounds ${ }^{a}$} \\
\hline \multicolumn{2}{|l|}{ Gases } \\
\hline Argon & $16,000 \mathrm{~m}^{3}\left(565,000 \mathrm{ft}^{3}\right)$ \\
\hline Helium & $10 \mathrm{~m}^{3}\left(350 \mathrm{ft}^{3}\right)$ \\
\hline Hydrogen & $1,000 \mathrm{~m}^{3}\left(35,500 \mathrm{ft}^{3}\right)$ \\
\hline Nitrogen & $5,300 \mathrm{~m}^{3}\left(187,000 \mathrm{ft}^{3}\right)$ \\
\hline Oxygen & $5,000 \mathrm{~m}^{3}\left(174,000 \mathrm{ft}^{3}\right)$ \\
\hline \multicolumn{2}{|l|}{ Liquids } \\
\hline Hydrochloric acid (HCl) & $0.5 \mathrm{~kg}(1 \mathrm{lb})$ \\
\hline Nitric acid $\left(\mathrm{HNO}_{3}\right)$ & $1 \mathrm{~kg}(2 \mathrm{lb})$ \\
\hline Polyethylene glycol & $20 \mathrm{~kg}(<45 \mathrm{lb})$ \\
\hline Sulfuric acid $\left(\mathrm{H}_{2} \mathrm{SO}_{4}\right)$ & $2 \mathrm{~kg}(5 \mathrm{lb})$ \\
\hline \multicolumn{2}{|l|}{ Solids, kg (lb) } \\
\hline Sodium hydroxide $(\mathrm{NaOH})$ & 16 kg (34 lb) \\
\hline Sodium nitrate $\left(\mathrm{NaNO}_{3}\right)$ & $85 \mathrm{~kg}(<200 \mathrm{lb})$ \\
\hline Zinc stearate & $20 \mathrm{~kg}(<45 \mathrm{lb})$ \\
\hline \multicolumn{2}{|l|}{ Nonprocess chemicals } \\
\hline \multicolumn{2}{|l|}{ Liquids } \\
\hline Alcohol & $225 \mathrm{~L}(60 \mathrm{gal})$ \\
\hline Hydraulic fluid & $4.5 \mathrm{~kg}(10 \mathrm{lb})$ \\
\hline General cleaning fluids & $225 \mathrm{~L}(60 \mathrm{gal})$ \\
\hline \multicolumn{2}{|l|}{ Radioactive process materials } \\
\hline \multicolumn{2}{|l|}{ Plutonium dioxide $\left(\mathrm{PuO}_{2}\right)$} \\
\hline Hot startup & $23.6 \mathrm{~kg}(52 \mathrm{lb})$ \\
\hline Annually for 3 years & $113.5 \mathrm{~kg}(250 \mathrm{lb})$ \\
\hline \multicolumn{2}{|l|}{ Uranium dioxide $\left(\mathrm{UO}_{2}\right)$} \\
\hline Cold startup & $510 \mathrm{~kg}(1,125 \mathrm{lb})$ \\
\hline Hot startup & $475 \mathrm{~kg}(1,045 \mathrm{lb})$ \\
\hline Annually for 3 years & $2,270 \mathrm{~kg}(5,000 \mathrm{lb})$ \\
\hline
\end{tabular}
inventory.

${ }^{a}$ Requirements for insignificant amounts will most likely be met from existing site 


\subsubsection{Utilities}

Utility connections at the sites being considered for the LA fabrication facility are currently installed and in use. For analysis purposes, it is not anticipated that additional connections will be required. Utility requirements beyond those necessary for maintenance of the building's present usage are based on those for the MOX fuel fabrication facility, scaled to $3 \%$, and then increased by a $200 \%$ contingency factor for bounding purposes. The original MOX requirements were developed from the NRC environmental report for the Westinghouse Recycle Fuels Plant (see Ref. 1, Appendix A) with a 200-MT MOX fabrication capacity. The annual requirements are calculated as

$$
24,000 \mathrm{MWh} \times(100 \mathrm{MT} / 200 \mathrm{MT}) \times 3 \% \times 200 \%=720 \mathrm{MWh} .
$$

The peak demand is based the MOX fabrication facility's peak demand of $<5 \mathrm{MW}(\mathrm{e})$ and is calculated as

$$
<5 \mathrm{MW}(\mathrm{e}) \times 1000 \mathrm{~kW}(\mathrm{e}) / \mathrm{MW}(\mathrm{e}) \times 3 \% \times 200 \%<300 \mathrm{~kW}(\mathrm{e})
$$

\subsubsection{Fuel Resources}

Fuel resource requirements for the LA fabrication facility are site dependent. Based on the MOX fabrication facility's generic fuel needs, it is assumed that the LA fabrication facility will require natural gas or coal for heating and electricity for sintering. Oil products or gasoline will be necessary for operation of two small generators and a small fleet of motorized vehicles.

Natural gas requirements for heating are calculated as

$$
920,000 \mathrm{~m}^{3} / \text { year } \times 3 \% \times 200 \% \text { contingency }=55,200 \mathrm{~m}^{3} / \text { year } .
$$

LLNL will use natural gas for heating.

Oil products in the form of diesel fuel are required for operation of emergency generators. Based on technical specifications and testing requirements for generator operability, ${ }^{3}$ each of two generators will operate $30 \mathrm{~h} /$ year. Testing is required for $1 \mathrm{~h}$ each month for verification of operation, $1 \mathrm{~h}$ twice a year for full-load and manual synchronization, and $24 \mathrm{~h}$ every 18 months to confirm capability for continuous operation. Assuming that peak capacity is $300 \mathrm{~kW}(\mathrm{e})$ and that approximately $50 \%$ of peak demand should be available for glove box ventilation, emergency lighting, and other required electrical support, two $150-\mathrm{kW}$ capacity generators will be necessary at the LA fabrication facility. Based on a consumption rate of $38 \mathrm{~L} / \mathrm{h}(10 \mathrm{gal} / \mathrm{h})$, requirements for oil products are calculated as follows:

$$
38 \mathrm{~L} / \mathrm{h} \times 30 \mathrm{~h} / \text { year } \times 2 \text { generators } \times 200 \% \text { contingency }=4560 \mathrm{~L} / \text { year } \cong 4600 \mathrm{~L} / \text { year } .
$$

Because of the facility size and the potential distances between areas being used to support the LA mission, a distance of up to 2.5 miles $(4 \mathrm{~km})$ between the LA fabrication facility and other areas is assumed. An estimate of gasoline required for operation of motorized vehicle usage is based on requirements of 5 miles round-trip for 10 trips daily at $\sim 0.38 \mathrm{~L} / \mathrm{mile}(0.1 \mathrm{gal} / \mathrm{mile})$. The standard days of operation are calculated in Sect. 5.1 as $365 \mathrm{~d}$ /year. The fuel consumption for motorized vehicles at the LA fabrication facility is estimated as 


$$
10 \mathrm{trips} / \mathrm{d} \times 5 \mathrm{miles} / \text { trip } \times 0.38 \mathrm{~L} / \text { mile } \times 365 \mathrm{~d} / \text { year }=6935 \mathrm{~L} / \text { year } \cong 6900 \mathrm{~L} / \text { year } .
$$

The total requirement for oil products is $\sim 11,500 \mathrm{~L} /$ year $(3,040 \mathrm{gal} / \mathrm{year})$.

\subsubsection{Water}

Based on the MOX fuel fabrication facility's water requirement of $25 \mathrm{gal} / \mathrm{d}(95 \mathrm{~L} / \mathrm{d})$ per employee, 24 employees working $250 \mathrm{~d}$ at the LA fabrication facility on the first shift, and 12 employees performing shift work for $365 \mathrm{~d}$, the annual sanitary water resource usage is calculated as

$(25 \mathrm{gal} / \mathrm{d}) \times[(24$ employees $\times 250 \mathrm{~d} / \mathrm{year})+(12$ employees $\times 365 \mathrm{~d} / \mathrm{year} \times 2 \mathrm{shifts})$

$$
+(12 \text { employees } \times 115 \mathrm{~d} / \text { year })]=403,500 \text { gal } / \text { year },
$$

where calculations of the number of employees are in Sect. 5.1.

Nonsanitary water requirements are based on scaling the MOX fuel fabrication facility ${ }^{1}$ with a 100-MT capacity to $10 \%$ of requirements. The $10 \%$ factor was used in lieu of $3 \%$ based on the nonlinear requirements for staffing between the MOX fuel fabrication facility and the LA fabrication facility. The usage is calculated as fo

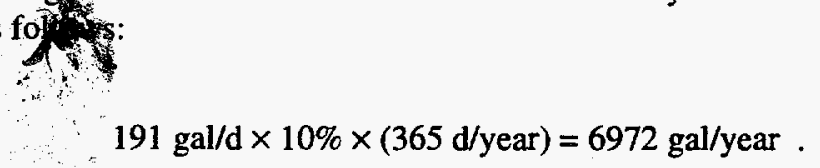

Total surface water usage is rounded to 411,000 gal/year $(1,600,000 \mathrm{~L} /$ year $)$. No groundwater requirements are expected for this facility.

\subsubsection{Process and Nonprocess Chemicals and Compounds}

Process and nonprocess chemicals in gas, liquid, and solid form will be required in the operation of the LA fabrication facility. Those chemicals required in significant quantities are identified in Table 6 . Most of the chemicals required will be available from existing site inventory.

It is assumed that the sintering furnace will have a purge rate of $30 \mathrm{~L} / \mathrm{min}$, requiring $-94 \%$ argon and $6 \%$ hydrogen for operations. This number is derived as a function of the purge rates for large production furnaces that are typically on the order of $10 \mathrm{ft}^{3} / \mathrm{min}$. Assuming that the sintering furnace for the LA program will require one-tenth of the typical purge rate, a rate of $1 \mathrm{ft}^{3} / \mathrm{min}$ would be reasonable. There are $28.3 \mathrm{~L} / \mathrm{ft}^{3}$, which rounds up to $30 \mathrm{~L} / \mathrm{ft}^{3}$, resulting in a $30-\mathrm{L} / \mathrm{min}$ purge rate.

Because of requirement calculations for some chemicals resulting in minimal quantities, the amounts required have been rounded upward for bounding purposes. The quantities of process and nonprocess chemicals required in quantifiable amounts were calculated based on projected uses and requirements that follow.

Alcohol: for process and nonprocess cleaning purposes

$5 \mathrm{gal} / \mathrm{month} \times 12 \mathrm{months} / \mathrm{year}=60 \mathrm{gal} / \mathrm{year}$

Argon: required for sintering furnaces $(30 \mathrm{~L} / \mathrm{min}) \times(525,600 \mathrm{~min} /$ year $) \times 0.001 \mathrm{~m}^{3} / \mathrm{L}=15,768 \mathrm{~m}^{3} /$ year $\cong 16,000 \mathrm{~m}^{3} /$ year

General cleaning fluids: for nonprocess cleaning purposes

$5 \mathrm{gal} / \mathrm{month} \times 12 \mathrm{months} / \mathrm{year}=60 \mathrm{gal} / \mathrm{year}$ 
Helium: required as process gas

$0.2 \mathrm{~m}^{3} /$ week $\times 52$ weeks/year $=10 \mathrm{~m}^{3} /$ year

Hydraulic fluid: lubricant

$0.2 \mathrm{lb} /$ week $\times 52$ weeks/year $\cong 10 \mathrm{lb} /$ year

Hydrochloric acid: required in service laboratory

$5 \mathrm{lb} \times 20 \%=1 \mathrm{lb} /$ year

Hydrogen: required in sintering furnaces

$(30 \mathrm{~L} / \mathrm{min}) \times(525,600 \mathrm{~min} /$ year $) \times 0.001 \mathrm{~m}^{3} / \mathrm{L} \times 6 \%=946 \mathrm{~m}^{3} /$ year $\cong 1000 \mathrm{~m}^{3} /$ year

Nitric acid: required in service laboratory

$8 \mathrm{lb} \times 20 \%=1.6 \mathrm{lb} /$ year $\cong 2 \mathrm{lb} /$ year

Nitrogen: required in glove boxes

$(1 \mathrm{~L} / \mathrm{min}) \times(525,600 \mathrm{~min} /$ year $) \times 0.001 \mathrm{~m}^{3} / \mathrm{L} \times 10$ glove boxes $=5256 \mathrm{~m}^{3} /$ year $\cong 5300 \mathrm{~m}^{3} /$ year

Oxygen: required for dry recycle process-assume $580 \mathrm{~h} /$ year dry recycle processing

$\left(5 \mathrm{ft}^{3} \mathrm{O}_{2} / \mathrm{min}\right) \times(60 \mathrm{~min} / \mathrm{h}) \times(680 \mathrm{~h} /$ year $)=\left(174,000 \mathrm{ft}^{3} \mathrm{O}_{2} /\right.$ year $) \equiv 4927 \mathrm{~m}^{3} \cong 5000 \mathrm{~m}^{3} \mathrm{O}_{2} /$ year

Polyethylene glycol: required in blending process

$700 \mathrm{lb} \times 3 \% \times 200 \%=44 \mathrm{lb} /$ year $\cong 45 \mathrm{lb} /$ year

Sodium hydroxide: required in laboratory scrubber

$170 \mathrm{lb} \times 20 \%=34 \mathrm{lb} /$ year

Sodium nitrate: required in laboratory scrubber

$3100 \mathrm{lb} \times 3 \% \times 200 \% \cong 186 \mathrm{lb} /$ year $\cong 200 \mathrm{lb} /$ year

Sulfuric acid: required in service laboratory

$17 \mathrm{lb} \times 20 \%=3.4 \mathrm{lb} /$ year $\cong 5 \mathrm{lb} /$ year

Zinc stearate: required in pellet pressing process

$670 \mathrm{lb} \times 3 \% \times 200 \%=40.2 \mathrm{lb} /$ year $\cong 45 \mathrm{lb} /$ year

\subsubsection{Radioactive Process Materials}

The radioactive process materials used at the LA fabrication facility are $\mathrm{PuO}_{2}$ and $\mathrm{UO}_{2}$. Based on the bounding case of $100 \mathrm{~g}$ plutonium per rod, 264 rods per assembly (full MOX), $5 \%$ plutonium for rods, and 10 full-MOX assemblies produced over a 3-year period, $113.5 \mathrm{~kg}(250 \mathrm{lb})$ of $\mathrm{PuO}_{2}$ and $2270 \mathrm{~kg}(5000 \mathrm{lb})$ $\mathrm{UO}_{2}$ would be required annually. The calculations are provided in Sects. 4.2.5.1 and 4.2.5.2.

\subsubsection{Plutonium requirements}

The conversion factor for plutonium to $\mathrm{PuO}_{2}=\left(\mathrm{mol}\right.$ wt $\left.\mathrm{PuO}_{2}\right) /(\mathrm{mol}$ wt plutonium $)=271.0 /$ $239.0=1.1339$.

Plutonium required for 3-year LA mission $=250 \mathrm{~kg}$ HM plutonium (Table 5)

Annual plutonium with rejection rate of $20 \%=250 \mathrm{~kg} \mathrm{HM}$ plutonium $\times 120 \% / 3$ years

$$
=100 \mathrm{~kg} \mathrm{HM} \text { plutonium/year }
$$

$100 \mathrm{~kg}$ HM plutonium $\times 1.1339=113.39 \mathrm{~kg} \mathrm{PuO} 2 \cong 113.5 \mathrm{~kg} \mathrm{PuO}_{2} /$ year 
The plutonium requirements for hot startup operations are

$$
(250 \mathrm{~kg} \mathrm{HM} \text { plutonium }) /(3 \text { years }) \times 25 \% \times 1.1339=23.6 \mathrm{~kg} \mathrm{PuO}_{2} .
$$

Total plutonium requirements for the $\mathrm{LA}$ fabrication facility for the 3-year mission are $364 \mathrm{~kg} \mathrm{PuO}_{2}$.

\subsubsection{Uranium requirements}

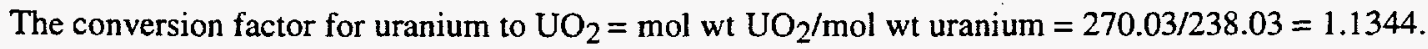

Uranium required for 3-year LA mission $=5000 \mathrm{~kg} \mathrm{HM}$ uranium (Table 5)

Annual uranium with rejection rate of $20 \%=5000 \mathrm{~kg} \mathrm{HM}$ uranium $\times 120 \% / 3$ years

$$
=2000 \mathrm{~kg} \mathrm{HM} \text { uranium } / \text { year }
$$

$2000 \mathrm{~kg} \mathrm{HM}$ uranium $\times 1.1344=2268.8 \mathrm{~kg} \mathrm{UO} 2 \equiv 2270 \mathrm{~kg} \mathrm{UO}_{2} /$ year

The uranium requirements for cold and hot startup operations during the first year of production follow.

Hot: (5000 kg HM uranium)/(3 years) $\times 25 \% \times 1.1344=472.67 \mathrm{~kg} \mathrm{UO}_{2} \cong 475 \mathrm{~kg} \mathrm{UO} 2$

Cold: $(5000 \mathrm{~kg} \mathrm{HM}$ uranium $) /(3$ years $) \times 27 \% \times 1.1344=510.49 \mathrm{~kg} \mathrm{UO} 2 \cong 510 \mathrm{~kg} \mathrm{UO}{ }_{2}$

Total uranium requirements for the LA fabrication facility for the 3-year mission are slightly less than $7,800 \mathrm{~kg}(17,200 \mathrm{lb}) \mathrm{UO}_{2}$. 


\section{EMPLOYMENT REQUIREMENTS}

\subsection{ANNUAL EMPLOYMENT REQUIREMENTS DURING OPERATION OF THE LA FABRICATION FACILITY}

Table 7 provides the annual number of employees by labor category, the number of shifts, the number of employees per shift, and the number of operating days per year for the LA fabrication facility. It is assumed that the facility will operate continuously with the primary work effort during standard business days of operation at the selected site. The standard days of operation were calculated as follows:

$$
(365 \mathrm{~d} / \text { year })-[(104 \text { weekend days })+(11 \text { holidays })]=250 \mathrm{~d} / \text { year } .
$$

The 11 holidays considered are New Year's Day, Martin Luther King Day, Good Friday, Memorial Day, Independence Day ( 2 days), Labor Day, Thanksgiving ( 2 days), and Christmas ( 2 days).

The number of employees in Table 7 was derived from a reduction in personnel required for the MOX fuel fabrication facility with consideration given for the nature of operations necessary to maintain 24-h performance. ${ }^{4}$ Twenty-four employees will be required on the standard operation shift. Twelve additional employees will be required on each of two alternate shifts, resulting in total staffing needs of 60 employees.

Many of these positions probably will be filled by existing employees at the site. This estimate is generic in nature, and some of the sites under consideration may require fewer employees based on existing infrastructure. For example, facilities with on-site plutonium processing facilities may require only a nominal increase in support personnel and management. Industrial support organizations (such as site superintendent, site security, emergency response, health services, and personnel support) and atmospheric and groundwater monitoring will be provided by the site operator because these facilities are currently being serviced by the site.

Based on the estimates for the MOX fuel fabrication facility, a personnel requirement was established if more than $80 \%$ effort of a full-time equivalent (FTE) was charged out to support the LA fabrication facility operation. ${ }^{4}$ Those efforts requiring less than $80 \%$ of an FTE were considered part of operations of the existing site. The assumptions used in consideration of staffing levels for the LA fabrication facility are given in Table 8.

\subsection{RADIATION DOSES (WHOLE BODY) TO INVOLVED WORKERS DURING MODIFICATION OF THE LA FABRICATION FACILITY}

We estimate that it will take about 3 months and 10 FTEs to remove the existing equipment from Buildings 332 and 334 . We do not think we can provide a good estimate, at this time, of the employees required to install the new systems. However, similar installations done in the past have required 15-20 FTEs for 9-12 months.

\subsection{RADIATION DOSES (WHOLE BODY) TO INVOLVED WORKERS DURING OPERATION OF THE LA FABRICATION FACILITY}

The provided dose estimates to workers are based on those found in 10 Code of Federal Regulations (CFR) 835 and the administrative control level (ACL) found in DOE N 441.1. Fissile material processing for the LA program will be conducted at a DOE site and should be subject to DOE N 441.1, a DOE notice that establishes a maximum allowable dose of $2 \mathrm{rem} / \mathrm{year}$ (see Table 9). ALARA will be the goal in all operations. The primary hazard in the LA program will be processing $\mathrm{PuO}_{2}$ powder and the possibility of inhalation of the $\mathrm{PuO}_{2}$ dust. Estimated dose to radiation workers for handling 3013 cans during $\mathrm{PuO}_{2}$ powder homogenization operations and blending with $\mathrm{UO}_{2}$ powder will be below the ACL found in DOE N 441.1. 
Table 7. Annual employment requirements during operation of the LA fabrication facility

\begin{tabular}{lcc}
\hline \multicolumn{1}{c}{ Labor category $a$} & $\begin{array}{c}\text { Number of } \\
\text { employees on one } \\
\text { shift of } 250 \mathrm{~d} / \text { year }\end{array}$ & $\begin{array}{c}\text { Number of employees on } \\
\text { each of three alternate } \\
\text { shifts of } 365 \mathrm{~d} / \text { year }^{b}\end{array}$ \\
\hline Officials and managers & 1 & 0 \\
Professionals & 4 & 0 \\
Technicians & 10 & 7 \\
Office and clerical & 2 & 0 \\
Craft workers (skilled) & 2 & 1 \\
Operatives (semiskilled) & 2 & 2 \\
Service workers & 3 & 2 \\
$\quad$ Total & 24 & 12 \\
\hline
\end{tabular}

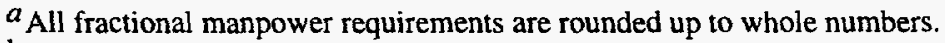

b $_{\text {Two }} 365 \mathrm{~d}$ /year shifts and one $115 \mathrm{~d} /$ year shift.

Table 8. Assumptions used in consideration of staffing levels for the LA fabrication facility

1. The facility will be built on an existing DOE site with a minimum of $4500 \mathrm{ft}^{2}$ available space $\left(3000 \mathrm{ft}^{2}\right.$ for MOX rod processing, $1000 \mathrm{ft}^{2}$ for bundling activities, and $500 \mathrm{ft}^{2}$ for fuel bundle storage).

2. The site will have an existing infrastructure in place to accept the LA mission.

3. Personnel will be required to support a process capacity of $\sim 2$ MT HM per year.

4. Personnel involved in SNM operations must work in pairs and follow specific safety precautions detailed by the site.

5. Personnel must attend required site training. A staffing requirement for training purposes has been included in this estimate.

6. Space will be allocated for safe secure transports (SSTs) carrying plutonium and transportation for uranium so that loading can be accomplished on a follow-up operating shift if the transport arrives near or following the close of standard business.

7. As with the MOX fuel fabrication facility estimate, the staffing requirements assume that $-20 \%$ of the employee's time will be taken through training, vacation, personal leave, or illness. Even though employees cannot necessarily transition from one position to another, a contingency was added to account for nonproductive time.

Table 9. Radiation doses (whole body) to involved workers during modification of the LA fabrication facility

\begin{tabular}{lr}
\hline Average maximum target annual dose to all involved workers at the & 500 \\
facility, mrem & 2000 \\
Maximum allowable administrative dose limit, mrem & 55 \\
\hline
\end{tabular}




\section{WASTES, EMISSIONS, AND EXPOSURES}

\subsection{WASTE GENERATED DURING FACILITY MODIFICATION}

No significant wastes, emissions, or exposures will be generated during modification of the identified space. Laboratories that will be modified contain "clean equipment" that can be removed and used elsewhere at LLNL. No radiation doses above background are anticipated during the facility modifications. Any construction debris generated from removal of the existing equipment and installation of new equipment would be disposed of according to approved DOE and LLNL procedures.

From Sect. 5.2, a total of -3000 workdays will be required to complete facility modifications. At $25 \mathrm{gal} / \mathrm{d}$ per worker, a total of $75,000 \mathrm{gal}$ of nonhazardous wastewater would be generated.

From Sect. 4.1, it is estimated that the only nonhazardous solid waste generated during facility modification will be due to scrap generated during equipment installation. Based on this assumption, it is estimated that a total of $500 \mathrm{ft}^{3}$ of nonhazardous solid waste would be generated to complete facility modifications.

\subsection{WASTES GENERATED DURING OPERATION OF THE FACILITY}

Table 10 provides the annual volume, total estimated volume, description, and anticipated treatment method by waste category for liquids and solids anticipated during operation of the LA fabrication facility.

A total of $0.4 \mathrm{mg} /$ year of plutonium is estimated to be released to the air during the operation of the LA MOX facility. This plutonium release corresponds to a total activity of $94 \mu \mathrm{Ci} /$ year. The total plutonium release includes two contributions; $0.3 \mathrm{mg} /$ year is expected to be released during normal operation of the plant and an additional $0.1 \mathrm{mg} /$ year during a one-time abnormal event (spilling the powder of one 3013-can).

The release during normal operation has been estimated from the releases reported in Ref. 2 for a 100-MT HM/year MOX plant with two lines. Reference 2 reports a release of $0.6 \mathrm{mg} / \mathrm{year}$ of plutonium. The LA MOX facility has only one line and a smaller capacity (about 2.5 MT HM/year). For conservatism, one-half of the releases of the large MOX plant (with two lines) has been estimated for the small LA MOX facility (with only one line), therefore the value of $0.3 \mathrm{mg} / \mathrm{year}$. No scaling consideration has been given to the much smaller capacity of the LA MOX facility (about 1/40 of the large MOX plant).

The release during the abnormal event has been calculated by dropping one 3013 can containing $4.5 \mathrm{~kg}$ of plutonium. From Ref. 5 (Table 4-13) the following factors were selected:

- $\mathrm{ARF}$ (airborne release fraction) $=3.3 \times 10^{-3}$

- $\mathrm{RF}$ (respirable factor) $=0.62$

-Also the efficiency of the HEPA filters in the glove box has been assumed to be $99.9 \%$ (equivalent to a release factor of $10^{-3}$ ) and the efficiency of the building HEPA filters as $99 \%$ (equivalent to a release factor of $10^{-2}$ ). Overall, the air emission for this event is

$$
4500 \mathrm{~g} \times 3.3 \times 10^{-3} \times 0.62 \times 10^{-3} \times 10^{-2}=0.092 \mathrm{mg} / \mathrm{year} \cong 0.1 \mathrm{mg} / \mathrm{year}
$$


Table 10. Estimated waste generated during operation of the LA fabrication facility

\begin{tabular}{|c|c|c|c|c|c|c|c|}
\hline \multirow{2}{*}{$\begin{array}{c}\text { Waste } \\
\text { category }\end{array}$} & \multicolumn{2}{|c|}{ Annual volume } & \multicolumn{2}{|c|}{ Total volume } & \multirow{2}{*}{$\begin{array}{c}\text { Waste } \\
\text { description }\end{array}$} & \multirow{2}{*}{$\begin{array}{c}\text { Anticipated } \\
\text { treatment }\end{array}$} & \multirow{2}{*}{$\begin{array}{l}\text { Disposal } \\
\text { method }^{a}\end{array}$} \\
\hline & $\left(\mathrm{m}^{3}\right.$ or $\left.\mathrm{L}\right)$ & $\left(\mathrm{ft}^{3}\right.$ or gal) & $\left(\mathrm{m}^{3}\right.$ or $\left.\mathrm{L}\right)$ & $\left(\mathrm{ft}^{3}\right.$ or $\left.\mathrm{gal}\right)$ & & & \\
\hline TRU-solid $\left(\mathrm{m}^{3}\right.$ or $\left.\mathrm{ft}^{3}\right)$ & 40 & 1,413 & 130 & 4,591 & $\begin{array}{l}\text { Glove box gloves } \\
\text { Bag-in plastic } \\
\text { Empty bottles } \\
\text { Filters } \\
\text { Scrapped equipment items } \\
\text { Furnace hardware } \\
\text { Wipes } \\
\text { Metal cans } \\
\text { Metallography waste }\end{array}$ & Compaction & $\begin{array}{l}\text { Off-site at Waste Isolation } \\
\text { Pilot Plant (WIPP) }\end{array}$ \\
\hline$T R U$-mixed $\left(\mathrm{m}^{3} \text { or } \mathrm{ft}^{3}\right)^{b}$ & & & & & $\begin{array}{l}\text { Organics from sintering } \\
\text { Sludges from liquids } \\
\text { Analytical waste }\end{array}$ & $\begin{array}{l}\text { From liquid treatment } \\
\text { absorption to TRU solid }\end{array}$ & Off-site at WIPP \\
\hline TRU-liquids (L/gal) & 200 & 53 & 650 & 172 & $\begin{array}{l}\text { Sludges from liquids } \\
\text { Analytical waste } \\
\text { Metallography waste }\end{array}$ & $\begin{array}{l}\text { Absorption to TRU solid } \\
\text { or liquid LLW }\end{array}$ & As solid off-site at WIPP \\
\hline$L L W-\operatorname{solid}\left(\mathrm{m}^{3}\right.$ or $\left.\mathrm{ft}^{3}\right)$ & 40 & 1,413 & 140 & 4,944 & $\begin{array}{l}\text { Room trash } \\
\text { Blotter paper } \\
\text { Wipes } \\
\text { Mop heads } \\
\text { Gloves/shoe covers } \\
\text { Solidified sludges } \\
\text { lon exchange resins } \\
\text { Discarded C-clothing } \\
\text { Metal cans and rods }\end{array}$ & $\begin{array}{l}\text { Compaction } \\
\text { Solidification } \\
\text { Metal melting }\end{array}$ & DOE on- or off-site disposal \\
\hline LLW-mixed (L/gal) & 1 & 0.3 & 4 & 1.1 & $\begin{array}{l}\text { Solvents from cleaning } \\
\text { Analytical waste } \\
\text { Sludges from liquids }\end{array}$ & Solidification & $\begin{array}{l}\text { RCRA-approved disposal } \\
\text { DOE on- or off-site } \\
\text { Commercial off-site }\end{array}$ \\
\hline LLW_liquid (L/gal) & 160,000 & 42,267 & 560,000 & 147,935 & $\begin{array}{l}\text { Decontaminated wastewater } \\
\text { Laundry wastewater } \\
\text { Analytical wastewater }\end{array}$ & $\begin{array}{l}\text { lon exchange } \\
\text { Evaporation/ } \\
\text { scrubber } \\
\text { Solidification }\end{array}$ & $\begin{array}{l}\text { Evaporation } \\
\text { NPDES }^{c} \text { permitted discharge }\end{array}$ \\
\hline Hazardous & 0 & & 0 & & None anticipated & & \\
\hline $\begin{array}{l}\text { Nonhazardous--solid } \\
\left(\mathrm{m}^{3} \text { or } \mathrm{ft}^{3}\right)\end{array}$ & 1,300 & 45,910 & 5,200 & 183,638 & $\begin{array}{l}\text { Office and lunch room trash } \\
\text { Packaging materials } \\
\text { Sewage sludges }\end{array}$ & $\begin{array}{l}\text { Compaction } \\
\text { Landfill }\end{array}$ & DOE on- or off-site landfill \\
\hline $\begin{array}{l}\text { Nonhazardous-liquid } \\
\text { (L/gal) }\end{array}$ & $1,600,000$ & 411,000 & $6,400,000$ & $1,644,000$ & Sewage waste & Sewage treatment & NPDES permitted discharge \\
\hline
\end{tabular}

${ }^{a_{\text {TRU }}}$ waste would be stored on-site at a permitted storage facility until off-site disposal at WIPP.

TRU waste would be stored on-site at a permitted storage facility until off-site disposal at WIPP.
$b_{\text {Note: }}$ The volume of TRU-mixed waste is a portion of TRU waste volume; mixed TRU waste is likely to come from sludges from wastewater treatment. Base numbers were generated in metric system to two significant figures; English units are conversions using factors provided in data call.

$c_{\text {NPDES }}=$ National Pollutant Discharge Elimination System. 


\section{ACCIDENT ANALYSIS}

\subsection{INTRODUCTION}

The LA fabrication process represents a very small scale process replication of the large 100-MT/year MOX fuel fabrication facility. The LA assembly fabrication will likely take place in an existing building complex. The process is envisioned to consist of a number (10-20) of glove boxes along with several hoppers, a press, a furnace, and a rod/bundle assembly area. The process can be done in a single large room, but it may also be done using several rooms (or buildings) with the material at the end stage of certain steps involving transportation and/or storage at another building. A generalized approach was taken because these specifics were unknown. Section 7.2 describes the accident analysis approach and mitigating design features that are assumed to be available. Section 7.3 describes the events that were selected for EIS evaluation and the estimated source terms that were chosen for all sites. These source terms are characterized here as "evaluation basis" because the facilities already exist and may have other design basis accidents that may or may not be similar to these accidents. Chemical source terms for the facility are discussed in Sect. 7.4. Site-specific aspects are discussed in Sect. 7.5.

\subsection{GENERAL APPROACH AND GENERIC DESIGN ASSUMPTIONS}

\subsubsection{Accident Analysis Approach}

In Ref. 2, a preliminary hazards analysis (PHA) was referenced for a 100-MT/year MOX fuel fabrication plant. This analysis identified 32 accidents which resulted from a variety of events. Specific events for the design-basis and beyond-design basis accidents were then selected from the hazard analysis to be further analyzed in the EIS. In that analysis, four design basis accidents and two beyond-design basis accidents were selected.

Several accident scenarios can be postulated for processing facilities, and many do not result in a source term that leaves the building. The objective of this accident analysis is to examine the frequency and estimated source terms of several events that are expected to result in a significant release from the building. Ventilation system design assumptions such as the use of HEPA filters that affect the leak-path factor are discussed in the next section. Using the methodology in Ref. 5, source terms are derived based on the combination of the material at risk, damage ratio, release fractions, respirable fractions, and the building leak-path factor.

The many unknowns and options associated with the LA fabrication plant did not warrant the performance of a building-/process-specific PHA for the LA facility. Currently, several different proposed fuel fabrication processes are combined with five sites. Knowledge concerning the PHA in Ref. 2 was combined with a knowledge of what the LA plant would generally be expected to look like. These aspects, along with a conservative estimate of the expected material flows of the plant, were used to select conservative accident source terms for the LA EIS analysis. Even though the scale of the LA plant is much smaller, it is thought that the LA facility will have many of the same accident initiators. Selected accident scenarios and the materials at risk were combined with bounding airborne release fractions and respirable fractions from DOE HDBK-3010-94 (Ref. 5) to derive conservative source terms.

With respect to estimated frequencies, the same approach that was taken in Ref. 2 is used. Frequency categories of anticipated $\left(10^{-1} /\right.$ year to $10^{-2} /$ year $)$, unlikely $\left(10^{-2} /\right.$ year to $10^{-4}$ /year $)$, extremely unlikely $\left(10^{-4} /\right.$ year to $10^{-6} /$ year $)$, and beyond the evaluation basis $\left(<10^{-6} /\right.$ year for most events) were usually assigned in this assessment.

No attempt was made to quantify all of the site-specific features that affect the accident analysis. Rather, a generic set (six events are evaluated) of source term magnitudes was used at each site. This set of source terms was derived based on a specified plant process and some general assumptions regarding facility mitigators. No claim is made that the accident source terms cited here bound or are bounded by the existing site-specific analysis. Some site specifics such as stack heights and seismic frequencies were deemed to be a necessary input. The site-specific characteristics used for this site are discussed in Sect. 7.5. 
The generic facility design assumptions that are made which are not site-specific are discussed in Sect. 7.2.2.

\subsubsection{Facility Design Assumptions}

\subsubsection{Plutonium isotopics and MOX fuel}

The isotopic compositions of the plutonium and various MOX blends are shown in Table 11. With respect to both the master mix and fuel blend, the uranium dominates (a minimum of $90 \%$ ) the weight percent of the mix. However, the radiological contribution of the low specific activities of the uranium isotopes ( -5 orders of magnitude) are so low (as compared to the plutonium isotopes) that they are ignored in the calculation of the source terms. In the event LEU rods are used in place of some MOX rods, the radiological contribution from the LEU rods will also be very low compared to the plutonium contribution. Therefore, the accident analyses only considered full MOX assemblies. The respective isotopic activities for the plutonium oxide powder and the MOX powder (conservatively assuming 10\% enrichment) or fuel are shown in this table. For each accident scenario, the appropriate $\left(\mathrm{PuO}_{2}\right.$, master mix, or fuel blend) isotopic ratios are applied to the quantities at risk to determine the material at risk. This number is then multiplied by the leak-path factor, damage ratio, airborne release fraction, and respirable fraction to determine the released source terms. The leak-path factor incorporates the assumption as to whether the release is filtered.

\subsubsection{Ventilation system}

A complete description of site-specific existing facility ventilation system specifics is beyond the scope of this section. However, in many process buildings, ventilation flows are maintained such that fresh air is taken through the cleanest radiological areas (such as adjacent offices) first. The air flow path is then drawn through the rooms where radiological work is performed. Most facility systems are designed such that glove boxes in these rooms are run at pressures lower than the room pressure to limit the spread of contamination in the event of glove box failure. Contamination would be drawn in to the glove box filter to limit contamination in the room. The exact facility specifics and credit for mitigating design features involved in accident situations will vary, depending on the facility selected and any facility modifications needed to support the LA mission. The intent of this section is to clearly describe the mitigators associated with the ventilation system that are credited in this analysis.

Generally, a number of filters and prefilters would exist in the release path for a typical processing building that supports plutonium processing. Usually one or more filters are at the ventilation outlet of the glove box. These filters are generally accessible in the room where the glove box is located. However, no credit in source term reduction was taken for these filters in this analysis. This approach was taken because arguments could be made that the events in question jeopardize the integrity of nearby filters. For the EIS purposes, this approach was deemed appropriate. However, this does not mean that in the safety analysis (which would be performed after the building has been selected) of various glove box designs, credit could never be taken for those (or other) filters. The decision of what equipment will be qualified (and credit assumed for in the various events) will be made during the subsequent safety review of the facility (e.g., after facility selection). This decision is beyond the scope of this EIS analysis because many facility specific aspects are not known at this stage of the analysis.

The glove box system may be served by a dedicated ventilation system that often ties into the overall system upstream of a series of HEPA filters. With respect to the analysis of events in which overall building confinement is maintained, credit (for the source term reduction) is taken for two serial HEPA filters that generally lie outside the building confinement. The efficiency is assumed to be $99.9 \%$ for the first filter. A HEPA filter at the factory is rated at $99.97 \%$, but when installed may test to $99.95 \%$. The facility may run with this for a while and allow some degradation in performance during the operating period. Thus, in practice, a $99.9 \%$ efficiency is judged to be appropriate for this filter (roughing filters and prefilters are ignored). A reduced efficiency of $99.0 \%$ is used for the second filter (resulting in a combined leak-path factor of $1 \times 10^{-5}$ ). These filters are considered in this analysis where confinement is assumed to be intact and to provide significant source term reduction. 
Table 11. Specific activities for process powders (source of isotopics-Ref. 1)

\begin{tabular}{lrcccc}
\multicolumn{6}{c}{ (source of isotopics-Ref. 1) } \\
\hline Isotope $^{a}$ & $\begin{array}{c}\text { Weight } \\
\text { percent }\end{array}$ & $\begin{array}{c}\text { Specific activity } \\
(\mathrm{Ci} / \mathrm{g})^{b}\end{array}$ & $\begin{array}{l}\text { Activity in } \\
\mathrm{PuO} \\
(\mathrm{Ci} / \mathrm{g} \mathrm{mix})^{c}\end{array}$ & $\begin{array}{c}\text { Activity in 30\% } \mathrm{PuO}_{2} \\
\text { enriched MOX mix } \\
(\mathrm{Ci} / \mathrm{g} \mathrm{mix})^{d}\end{array}$ & $\begin{array}{c}\text { Activity in } 10 \% \mathrm{PuO}_{2} \\
\text { enriched MOX mix } \\
(\mathrm{Ci} / \mathrm{g} \mathrm{mix})^{d}\end{array}$ \\
\hline${ }^{238} \mathrm{Pu}$ & 0.03 & $1.712 \times 10^{1}$ & $4.530 \times 10^{-3}$ & $1.359 \times 10^{-3}$ & $4.530 \times 10^{-4}$ \\
${ }^{239} \mathrm{Pu}$ & 92.44 & $6.204 \times 10^{-2}$ & $5.045 \times 10^{-2}$ & $1.514 \times 10^{-2}$ & $5.045 \times 10^{-3}$ \\
${ }^{240} \mathrm{Pu}$ & 6.47 & $2.270 \times 10^{-1}$ & $1.293 \times 10^{-2}$ & $3.879 \times 10^{-3}$ & $1.293 \times 10^{-3}$ \\
${ }^{241} \mathrm{Pu}$ & 0.05 & $1.030 \times 10^{2}$ & $4.542 \times 10^{-2}$ & $1.363 \times 10^{-2}$ & $4.542 \times 10^{-3}$ \\
${ }^{242} \mathrm{Pu}$ & 0.10 & $3.926 \times 10^{-3}$ & $3.463 \times 10^{-6}$ & $1.039 \times 10^{-6}$ & $3.463 \times 10^{-7}$ \\
${ }^{241} \mathrm{Am}$ & 0.90 & $3.428 \times 10^{0}$ & $2.721 \times 10^{-3}$ & $8.163 \times 10^{-3}$ & $2.721 \times 10^{-3}$ \\
\hline
\end{tabular}

$a_{\text {The activity of }}{ }^{235} \mathrm{U}$ and ${ }^{238} \mathrm{U}$ are ignored for all mixes because of their low specific activities as compared to the plutonium isotopes.

${ }^{b}$ Specific activities are taken from "Table of Radioactive Isotopes" in Browne and Firestone. ${ }^{6}$

${ }^{c} \mathrm{Based}_{\text {on }} \mathrm{PuO}_{2}$ mix being $88.2 \%$ plutonium by weight.

$d_{30 \%}$ is master mix; $10 \%$ is a conservative estimate for fuel blend. 


\subsubsection{Process flows}

Table 12 shows the process inventories and material flows used for the accident analysis. The average plutonium enrichment is nominally taken to be $5 \%$ for the fuel. However, because some fuel blends could go higher, an upper bound of $10 \%$ plutonium enrichment was selected. Table 12 was generally constructed on that basis. A $30 \%$ master mix blend was also selected. Table 12 was not intended to rigidly define the fuel fabrication material process because a number of candidate processes (with different material balances) may be used in the facility. Because the purpose of this table is to provide materials at risk, a conservative estimate of the maximum amount of material at a process station or in interim storage at a certain location was made.

Table 12. Estimated maximum station inventories for LA fabrication plant ${ }^{a}$

\begin{tabular}{|c|c|c|c|c|}
\hline Location/material station & Quantity (g) & $\mathrm{PuO}_{2}$ or $\mathrm{MOX}$ & Physical form & $\begin{array}{l}\text { Barriers to release } \\
\text { (to the room) }\end{array}$ \\
\hline Plutonium storage vault & 400,000 & $\mathrm{PuO}_{2}$ & Fine powder & Storage cans/vault \\
\hline $\begin{array}{l}\text { Plutonium oxide ( } 2 \text { cans in } \\
\text { process) }\end{array}$ & 10,000 & $\mathrm{PuO}_{2}$ & Fine powder & $3013 \mathrm{can}^{8}$ \\
\hline $\begin{array}{l}\text { Plutonium oxide loading } \\
\text { vessel }\end{array}$ & 16,000 & $\mathrm{PuO}_{2}$ & Fine powder & Steel vessel/glove box \\
\hline Master mix vessel & 53,000 & MOX ( $30 \%$ blend) & Fine powder & Steel vessel/glove box \\
\hline Master mix powder storage & 107,000 & MOX (30\% blend) & Fine powder & $\begin{array}{l}\text { Interim storage } \\
\text { cans/glove box }\end{array}$ \\
\hline V-blender & 40,000 & MOX (10\% blend) & Fine powder & $\begin{array}{l}\text { Rotating steel } \\
\text { vessel/glove box }\end{array}$ \\
\hline MOX blend storage & 320,000 & MOX (10\% blend) & Fine powder & $\begin{array}{l}\text { Interim storage } \\
\text { cans/glove box }\end{array}$ \\
\hline MOX granulation area & 10,000 & MOX (10\% blend) & $\begin{array}{l}\text { Pressed/very } \\
\text { coarse powder }\end{array}$ & Machinery/glove box \\
\hline MOX pellet press & 1,000 & MOX (10\% blend) & $\begin{array}{l}\text { Pressed to } 0.6 \\
\text { theoretical } \\
\text { density (TD) }\end{array}$ & $\begin{array}{l}\text { Inside of press/glove } \\
\text { box }\end{array}$ \\
\hline $\begin{array}{l}\text { MOX green pellet storage (in } \\
\text { pellet press area) }\end{array}$ & 80,000 & MOX (10\% blend) & $\begin{array}{l}\text { Pressed to } 0.6 \\
\text { TD }\end{array}$ & $\begin{array}{l}\text { Interim storage } \\
\text { cans/glove box }\end{array}$ \\
\hline Pellet sintering furnace & 40,000 & MOX (10\% blend) & $\begin{array}{l}\text { Green and } \\
\text { sintered }\end{array}$ & $\begin{array}{l}\text { Inside furnace/glove } \\
\text { box }\end{array}$ \\
\hline Sintered pellet storage & 160,000 & MOX (10\% blend) & Sintered pellets & $\begin{array}{l}\text { Interim storage } \\
\text { cans/glove box }\end{array}$ \\
\hline $\begin{array}{l}\text { Pellet grinding area/ground } \\
\text { sintered pellets }\end{array}$ & 10,000 & MOX (10\%.blend) & $\begin{array}{l}\text { Grindings of } \\
\text { sintered pellets }\end{array}$ & Containers/glove box \\
\hline $\begin{array}{l}\text { Pellet grinding area/dust } \\
\text { control area }\end{array}$ & 100 & MOX (10\% blend) & Fine powder & Loose dust/glove box \\
\hline Pellet inspection & 4,000 & MOX ( $10 \%$ blend) & Finished pellets & Trays/glove box \\
\hline $\begin{array}{l}\text { Fuel rod loading, inspection, } \\
\text { and storage }\end{array}$ & 20,000 & MOX (10\% blend) & Finished pellets & $\begin{array}{l}\text { About ten rods if } \\
\text { cladded }\end{array}$ \\
\hline $\begin{array}{l}\text { Bundle assembly and storage } \\
\text { (end of fabrication) }\end{array}$ & $7,200,000$ & $\begin{array}{l}\text { MOX (5\% average } \\
\text { blend) }\end{array}$ & Finished pellets & $\begin{array}{l}\text { Cladded in ten } \\
\text { bundles }\end{array}$ \\
\hline Scrap recovery area & 10,000 & $\mathrm{MOX}$ and $\mathrm{PuO}_{2}$ & $\begin{array}{l}\text { Mostly green and } \\
\text { sintered pellets }\end{array}$ & Few dispersibles \\
\hline
\end{tabular}

$a_{\text {No more than }} 32 \mathrm{~kg}$ of $\mathrm{PuO}_{2}$ (a batch) is used in the process line.

Source: Ref. 8. 
It is important to remember that with respect to assumed process flows, no more than $32 \mathrm{~kg}$ of plutonium oxide is ever assumed to be in the process line between the plutonium oxide vessel and the fuel rod loading step. As a result, no more than $32 \mathrm{~kg}$ of plutonium oxide (which is about $28 \mathrm{~kg}$ of pure plutonium) would be at risk in the process line, except for events that involve the vault (which is involved in beyond-evaluation basis events). The $32 \mathrm{~kg}$ of oxide does not include the two cans containing $5 \mathrm{~kg}$ of pure plutonium oxide that are assumed to be in process between the vault and the oxide loading vessel. Thus, a total of $42 \mathrm{~kg}$ of oxide in powder form has been considered in this analysis. Finished fuel rods are not considered because they are generally nondispersible as compared to powder. No effort has been made to model site-specific process flows and distinguish corresponding risk differences because there are so many process and facility unknowns at present. Rather, a generic (but thought to be generally conservative) process flow assumption has been made for all sites. Site-specific differences considered in the analysis are discussed in Sect. 7.5.

For most, if not all accident scenarios, materials at risk will be subjected to orders of magnitude multipliers in the calculation to determine the released source term. Thus, a high level of accuracy is not warranted at this stage of the analysis. Table 12 was used in combination with Ref. 5 and knowledge of the accident dynamics to obtain the source terms for the LA fabrication facility. In each accident scenario, a material at risk assumption is made at each station, depending on the event and energetics. Table 12 also lists the barriers to release that would be found inside the glove box. Generally, those materials that are inside interim storage cans were considered to be the most vulnerable to dispersion.

It is assumed that large amounts of $\mathrm{PuO}_{2}$ powder would be safely stored in appropriate containers 8 inside a vault or existing storage location. Considerable credit is taken for this vault (and/or the plutonium oxide containers), and it is assumed that the entire plutonium material feed requirement is in the vault at the start of the mission. It was conservatively assumed that $400 \mathrm{~kg}$ of oxide powder is in the vault at the start of the process. This inventory is held in 80 cans, each of which holds $5 \mathrm{~kg}$ of oxide powder $(4.4 \mathrm{~kg}$ of plutonium).

The overall layout of the facility is such that from 10-20 glove boxes are accommodated. The equipment is considered to be located in the same room, and generally, little credit is taken for segregation of the processes. Little credit is also taken for the glove boxes. The glove boxes are generally assumed to fail in the postulated events. This may or may not accurately portray the process line once it is designed (because glove boxes with a robust design may be used). However, this approach is thought to be conservative.

Finished fuel assemblies and clad rods were considered in this analysis but are thought to be generally nondispersible. Accidents that involve this inventory are thought to be bounded by the accidents involving the vault and the other in-process steps where dispersible powders are involved.

\subsection{SELECTED EVENTS FOR THE LA EIS ANALYSIS}

\subsubsection{Criticality Event}

\subsubsection{Discussion}

The prevention of criticality events is a major goal of the criticality safety program and is an important part of the overall conduct of operations for the facility. Within the nuclear processing industry, such prevention programs have successfully reduced the number of inadvertent criticalities over the years. The goal of the criticality safety program is to attempt (as much as is reasonably possible) to make the possibility of a criticality less than credible (generally accepted to be $<1 \times 10^{-6} /$ year frequency). Reference 9 establishes the DOE's nuclear criticality safety program requirements. Similarly, NRC also requires a criticality safety program, and those requirements are assumed to be implemented at the LA fabrication facility.

The risk impact associated with an inadvertent criticality event is highest with respect to workers located in the immediate vicinity (health impacts up to and including death could occur from prompt gamma and neutron doses). Collocated workers and the public would be affected to a lesser degree. The major dose pathways for these impacts are likely to be cloud shine (noble gases) and inhalation (mostly associated with the radioiodines). 
With respect to the LA fabrication plant, criticalities could be postulated in several areas (i.e., powder storage, the glove boxes involved in mixing, the furnace, and possibly the fuel rod storage area). The estimated frequencies associated with these events will vary depending on the controls in place, the number of operator movements, and the amount of fissile material present. A generic approach was taken with respect to the selection of the specifics of this event rather than selecting a criticality scenario associated with a specific operation in the LA fabrication.

\subsubsection{Source term}

The significant quantities of fissile materials in LA necessitate consideration of a criticality event. Because a limited number of rods are being made, a criticality event associated with a large array of fuel rods was not selected for this event. Because sources of moderation may be assumed to be either accidentally or inadvertently introduced into the glove boxes/equipment, the limiting fission yield for the facility was based on a scenario for a moderated powder or moderated solid criticality. In Ref. 9 (p. 6-24) dry powder and metal criticalities are quoted at a conservative yield of $1 \times 10^{17}$ fissions. A reference yield of $1 \times 10^{8}$ fissions is considered conservative for fully moderated and reflected solids. Therefore, a conservative selection of $1 \times 10^{18}$ fissions was made for the evaluation of this criticality event.

It is acknowledged that a dry criticality could potentially aerosolize surrounding plutonium and generate respirable particles. The amount of aerosolization is expected to be very small, and the presence of multiple filters would be an effective mitigator against the spread of plutonium out of the ventilation system. Thus, no plutonium was assumed to constitute the source term with respect to exposure of the collocated workers and the public that are outside of the building. Other events involving significant plutonium releases are discussed later.

With respect to release fractions associated with the fission products, it would be expected that a powder would have a surface area such that all noncondensible gases (such as the nobles) and all radioiodines would escape. However, if the criticality involved plutonium, which was in a relatively low surface area to volume ratio, the release fraction associated with the noble gases and radioiodines would be considerably less. In consideration of the present unknown specifics associated with this event, it was deemed conservative and appropriate to select the release fractions for both the nobles and the radioiodines as 1.0. Fission product yields from Table 6-9 of Ref. 5 (a plutonium solution of unknown isotopics for a reference yield of $1 \times 1 b^{9}$ fissions) were selected, and consideration of the selected yield of $1 \times 16^{8}$ fissions resulted in scaling the source terms.

The chosen source term specifics for the evaluation basis criticality event are shown in Table 13. As previously discussed, a conservative fission yield (moderated vs dry criticality) was combined with a conservative release fraction (for a powder vs moderated criticality). Thus, the source term in Table 13 is judged to be very conservative. The release height should be selected as the appropriate stack height for the facility where dose consequences are being calculated. The leak-path factor was taken as 1.0.

\subsubsection{Frequency estimate}

Criticalities have occurred considerably less frequently than in the earlier days of nuclear research, development, and operations. A number of these accidents are discussed in Ref. 10. None of these accidents are specifically associated with dry plutonium powder. However, several accidents involving dry metal, moderated metals, and fuel rods have occurred during the last 50 years. The fact that $30-40$ criticalities in the United States have historically (mostly in the 1940s, 1950s, and 1960s) occurred suggests that the accident spectrum analyzed for this facility should contain a criticality at a low estimated frequency. As was the case in Ref. 2, a frequency estimate of extremely unlikely $\left(1 \times 10^{-4}\right.$ to $1 \times 10^{-6}$ /year) is still judged to be appropriate for this event. However, the frequency of this event is judged to be somewhat less (perhaps 1 order of magnitude) than that at the large plant (100 MT/year vs 2 MT/year) because of the simplicity of the LA plant and the lower amounts of fissile material being handled. 
Table 13. Source term for the evaluation basis criticality event (stack release with a relatively short duration)

\begin{tabular}{ll}
\hline Isotope & $\begin{array}{c}\text { Released radioactivity } \\
(\mathrm{Ci})\end{array}$ \\
\hline${ }^{83} \mathrm{~m} \mathrm{Kr}$ & $1.1 \times 10^{1}$ \\
${ }^{83} \mathrm{~m} \mathrm{Kr}$ & $7.1 \times 10$ \\
${ }^{85} \mathrm{Kr}$ & $8.1 \times 10^{-4}$ \\
${ }^{87} \mathrm{Kr}$ & $4.3 \times 10^{1}$ \\
${ }^{88} \mathrm{Kr}$ & $2.3 \times 10^{1}$ \\
${ }^{89} \mathrm{Kr}$ & $1.3 \times 10^{3}$ \\
${ }^{131} \mathrm{~m} \mathrm{Xe}$ & $1.0 \times 10^{-2}$ \\
${ }^{133} \mathrm{~m} \mathrm{Xe}$ & $2.2 \times 10^{-1}$ \\
${ }^{133} \mathrm{Xe}$ & $2.7 \times 10$ \\
$135 \mathrm{~m} \mathrm{Xe}$ & $3.3 \times 10^{2}$ \\
${ }^{135} \mathrm{Xe}$ & $4.1 \times 10^{1}$ \\
${ }^{137} \mathrm{Xe}$ & $4.9 \times 10^{3}$ \\
$138 \mathrm{Xe}$ & $1.1 \times 10^{3}$ \\
${ }^{131} \mathrm{I}$ & $1.1 \times 10$ \\
${ }^{132} \mathrm{I}$ & $1.2 \times 10^{2}$ \\
${ }^{133} \mathrm{I}$ & $1.6 \times 10^{1}$ \\
${ }^{134} \mathrm{I}$ & $4.3 \times 10^{2}$ \\
${ }^{135} \mathrm{I}$ & $4.5 \times 10^{1}$ \\
\hline
\end{tabular}

\subsubsection{Evaluation Basis Seismic Event}

\subsubsection{Discussion}

A seismic event appropriate for the facility's evaluation basis was selected. In this event, major portions of the process line glove boxes are assumed to be breached with the contents available for release. In such an event, the focus was on the dispersible powders that would be at the powder blending stations. The storage vault and receiving area are assumed to have suitable containers for plutonium oxide that will survive the earthquake ( 3013 cans with double containment). ${ }^{7}$ In-process material in glove boxes is, however, more vulnerable as are powder storage areas that may exist. Finished pellets and fuel rods are thought to be generally nondispersible even though they may escape the glove boxes. In this seismic event, the glove boxes are breached and assumed to fail based on a scenario of falling debris and equipment inside the room. The building confinement and ventilation system are assumed to remain intact, resulting in a filtered stack release.

\subsubsection{Source term}

Because the material in the vault is assumed to be in 3013 cans (which have double containment), no material was judged to be released from this area in this event. Table 14 shows the materials in process along with the release fractions and respirable fractions that were used. The total isotopic source term is shown summarized at the bottom for each plutonium isotope, as is the total amount of plutonium released. Because only $32 \mathrm{~kg}$ of plutonium oxide is allowed in a single batch, it was assumed that this batch was split in inventory between the master mix and fuel blend mix stations. This material was assumed to be in temporary storage cans at their respective stations. Another $10 \mathrm{~kg}$ of plutonium oxide in the form of powder is assumed to be at risk and open within the glove box. This material is from two cans that are taken out of the vault and prepared for loading (no credit for the 3013 can double containment). 
Table 14. Source term for the evaluation basis seismic event

\begin{tabular}{|c|c|c|c|c|c|c|c|c|c|c|c|c|}
\hline $\begin{array}{l}\text { Processing } \\
\text { station }\end{array}$ & $\begin{array}{c}\text { Material at } \\
\text { risk } \\
\text { (g) }\end{array}$ & $\begin{array}{l}\text { Physical } \\
\text { form }\end{array}$ & $\begin{array}{l}\text { Damage } \\
\text { ratio }\end{array}$ & $\begin{array}{l}\text { Airbome } \\
\text { release } \\
\text { fraction }\end{array}$ & $\begin{array}{l}\text { Respirable } \\
\text { fraction }\end{array}$ & $\begin{array}{l}\text { Leak-path } \\
\text { factor }\end{array}$ & $\begin{array}{l}{ }^{238} \mathrm{Pu} \\
\text { released }\end{array}$ & ${ }^{239} \mathrm{Pu}$ & $\begin{array}{l}{ }^{240} \mathrm{Pu} \\
\text { released }\end{array}$ & ${ }^{241} \mathrm{Pu}$ & $\begin{array}{l}242 \mathrm{Pu} \\
\text { released }\end{array}$ & $\begin{array}{l}241 \mathrm{Am} \\
\text { released }\end{array}$ \\
\hline $\begin{array}{l}\text { Plutonium oxide } \\
\text { ( } 2 \text { cans) }\end{array}$ & 10,000 & $\begin{array}{l}\text { Fine powder } \\
\mathrm{PuO}_{2}\end{array}$ & 1.00 & $1.00 \times 10^{-2}$ & 0.20 & $1.00 \times 10^{-5}$ & $9.06 \times 10^{-7}$ & $1.01 \times 10^{-5}$ & $2.59 \times 10^{-6}$ & $9.08 \times 10^{-6}$ & $6.93 \times 10^{-10}$ & $5.44 \times 10^{-6}$ \\
\hline $\begin{array}{l}\text { Master mix } \\
\text { powder storage }\end{array}$ & 53,000 & $\begin{array}{l}\text { Fine powder } \\
\text { MOX ( } 30 \% \\
\text { blend) }\end{array}$ & 1.00 & $1.00 \times 10^{-3}$ & 0.10 & $1.00 \times 10^{-5}$ & $7.20 \times 10^{-8}$ & $8.02 \times 10^{-7}$ & $2.06 \times 10^{-7}$ & $7.22 \times 10^{-7}$ & $5.51 \times 10^{-11}$ & $4.33 \times 10^{-7}$ \\
\hline $\begin{array}{l}\text { MOX blend } \\
\text { storage }\end{array}$ & 160,000 & $\begin{array}{l}\text { Fine powder } \\
\text { MOX (10\% } \\
\text { blend) }\end{array}$ & 1.00 & $1.00 \times 10^{-3}$ & 0.10 & $1.00 \times 10^{-5}$ & $7.25 \times 10^{-8}$ & $8.07 \times 10^{-7}$ & $2.07 \times 10^{-7}$ & $7.27 \times 10^{-7}$ & $5.54 \times 10^{-11}$ & $4.35 \times 10^{-7}$ \\
\hline \multicolumn{7}{|c|}{$\begin{array}{l}\text { Total isotopic source term, } \mathrm{Ci} \\
\text { Total source term, } \mathrm{Pu} / \mathrm{Am} \text { mix, } \mathrm{g}\end{array}$} & $1.05 \times 10^{-6}$ & $\begin{array}{l}1.17 \times 10^{-5} \\
2.0454 \times 10^{-4}\end{array}$ & $3.00 \times 10^{-6}$ & $1.05 \times 10^{-5}$ & $8.03 \times 10^{-10}$ & $6.31 \times 10^{-6}$ \\
\hline
\end{tabular}


In a seismic event, powders in various pieces of equipment will be subjected to many different damage ratios and release fractions. For the pure oxide powder at the feed station, the entire amount was conservatively subjected to a release fraction corresponding to debris falling into powder (no credit for the two open cans, utilizing a $1 \times 10^{-2}$ airborne release fraction and 0.2 respirable fraction for the total release fraction from Ref. 5 ). With respect to the $32-\mathrm{kg}$ batch of in-process powder, the powder stored in interim containers is assumed to be subjected to damage. A $1 \times 10^{3}$ airborne release fraction and 0.1 respirable fraction for the total release fraction was selected from Ref. 5 based on falling equipment impacting storage cans of powder. No credit is taken for the glove boxes that were postulated to fail. However, other portions of the process operation were assumed to be resistant to the event because of the material form. Finished pellets and fuel rods were not considered to constitute a significant portion of dispersible material. The source term is assumed to be filtered (leak-path factor of $1 \times 10^{-5}$ ) and released to a stack.

\subsubsection{Frequency estimate}

The frequency estimate for this event varies widely, depending on the site selected (and its respective seismic profile), the building used (and its evaluation basis), and the internal arrangement of equipment (see Sect. 7.5). Generally, a frequency estimate of $1 \times 10^{-2}$ to $1 \times 10^{-4}$ is used for this event (the frequency is usually closer to lower end of this range).

\subsubsection{Evaluation Basis Fire Event}

\subsubsection{Discussion}

A large spectrum of fire events ranging from small fires with no impacts to large multiroom fires with major impacts can be postulated for the LA fabrication building. Unlike the large MOX fabrication facility, the LA mission will take place in an existing building. While many existing buildings within the DOE complex are adequately covered by an existing fire protection program, it is reasonable to conclude that existing buildings might be more susceptible to fires (as compared to a new facility where fire protection can be incorporated into the design). However, the existing buildings must still meet the appropriate DOE orders.

A source of combustible material such as hydraulic fluid, alcohol, contaminated combustibles, or some other material is assumed to be present in the room. In addition, adjoining facilities such as offices may exist in the building and add to the risk of fires in the facility. The glove boxes are assumed to fail in the fire. This event is assumed to be a moderate-size room fire. The MOX powder that is in interim storage is assumed to be at risk and subjected to the thermal stress of the fire, because the glove box fails. Because of the limited combustible material and/or the existence of mitigators such as a fire protection system or. arrival of the firefighting unit, the event is assumed to be terminated. The severity of this fire is not enough to jeopardize the overall confinement characteristics of the building.

\subsubsection{Source term}

Table 15 shows the materials in process along with the release fractions that were used. With respect to the oxide containers $(10 \mathrm{~kg}$ ), a high release fraction was selected based on a pressurized gas release combined with powder. This corresponds to a highly pressurized, strong, single can that ruptures under a high thermal stress because of pressure and ejects powder from the breached container. A $10 \%$ damage ratio (thus, $500 \mathrm{~g}$ of powder are subjected to the release fraction) was selected on the basis that the release fraction does not apply universally to all of the powder in the can (the release fraction will go down as larger cans of powder are subjected to the energetics).

The 32-kg inventory in the process area was assumed to be evenly split between the master mix and MOX fuel blend storage areas. The entire interim storage inventory of MOX powder is assumed to be subjected to a release fraction corresponding to thermal stress $\left(6 \times 10^{3}\right.$ airborne release fraction and 0.01 respirable fraction from Ref. 5). Green pellets, finished pellets, and fuel rods were not considered to constitute a significant portion of dispersible material. The material is assumed to be filtered and released to a stack. The scrap area was assumed to contain mostly solid material and was not judged to be a significant 
Table 15. Source term for the evaluation basis fire

\begin{tabular}{|c|c|c|c|c|c|c|c|c|c|c|c|c|}
\hline $\begin{array}{l}\text { Processing } \\
\text { station }\end{array}$ & $\begin{array}{c}\text { Material at } \\
\text { risk } \\
\text { (g) }\end{array}$ & $\begin{array}{l}\text { Physical } \\
\text { form }\end{array}$ & $\begin{array}{l}\text { Damage } \\
\text { ratio }\end{array}$ & $\begin{array}{l}\text { Airborne } \\
\text { release } \\
\text { fraction }\end{array}$ & $\begin{array}{l}\text { Respirable } \\
\text { fraction }\end{array}$ & $\begin{array}{l}\text { Leak-path } \\
\text { factor }\end{array}$ & ${ }_{\text {released }}^{238} \mathrm{Pu}$ & ${ }^{239} \mathrm{Pu}$ & ${ }^{240} \mathrm{Pu}$ & ${ }^{241} \mathrm{Pu}$ & $\begin{array}{l}{ }^{242} \mathrm{Pu} \\
\text { released }\end{array}$ & ${ }_{\text {released }}^{241}$ Am \\
\hline $\begin{array}{l}\text { Plutonium oxide } \\
\text { ( } 2 \text { cans) }\end{array}$ & 10,000 & $\begin{array}{l}\text { Fine powder } \\
\mathrm{PuO}_{2}\end{array}$ & 0.10 & $1.00 \times 10^{-1}$ & 0.70 & $1.00 \times 10^{-5}$ & $3.17 \times 10^{-6}$ & $3.53 \times 10^{-5}$ & $9.05 \times 10^{-6}$ & $3.18 \times 10^{-5}$ & $2.42 \times 10^{-9}$ & $1.90 \times 10^{-5}$ \\
\hline $\begin{array}{l}\text { Master mix } \\
\text { powder storage }\end{array}$ & 53,000 & $\begin{array}{l}\text { Fine powder } \\
\text { MOX ( } 30 \% \\
\text { blend) }\end{array}$ & 1.00 & $6.00 \times 10^{-3}$ & 0.01 & $1.00 \times 10^{-5}$ & $4.32 \times 10^{-8}$ & $4.81 \times 10^{-7}$ & $1.23 \times 10^{-7}$ & $4.33 \times 10^{-7}$ & $3.30 \times 10^{-11}$ & $2.60 \times 10^{-7}$ \\
\hline $\begin{array}{l}\text { MOX blend } \\
\text { storage }\end{array}$ & 160,000 & $\begin{array}{l}\text { Fine powder } \\
\text { MOX (10\% } \\
\text { blend) }\end{array}$ & 1.00 & $6.00 \times 10^{-3}$ & 0.01 & $1.00 \times 10^{-5}$ & $4.35 \times 10^{-8}$ & $4.84 \times 10^{-7}$ & $1.24 \times 10^{-7}$ & $4.36 \times 10^{-7}$ & $3.32 \times 10^{-11}$ & $2.61 \times 10^{-7}$ \\
\hline \multicolumn{7}{|c|}{$\begin{array}{l}\text { Total isotopic source term, Ci } \\
\text { Total source term, Pu/Am mix, } \mathrm{g}\end{array}$} & $3.26 \times 10^{-6}$ & $\begin{array}{l}3.63 \times 10^{-5} \\
6.343 \times 10^{-4}\end{array}$ & $9.30 \times 10^{-6}$ & $3.27 \times 10^{-5}$ & $2.49 \times 10^{-9}$ & $1.96 \times 10^{-5}$ \\
\hline
\end{tabular}


source of dispersible material. As with other source terms no credit was taken for in-facility filters, as these may fail because of the fire. The source term is filtered and released to a stack.

\subsubsection{Frequency estimate}

The frequency estimate of fires depends on the conduct of operations, the building selected, the adequacy of the fire protection program, and a number of other variables. A frequency estimate of between $1 \times 10^{-2} /$ year and $1 \times 10^{-4} /$ year (unlikely) is judged to be appropriate for this event because a relatively small area is assumed to be involved.

\subsubsection{Evaluation Basis Explosion Event}

\subsubsection{Discussion}

As was the case in Ref. 2, an explosion event was postulated for the sintering furnace in the LA fabrication facility. A nonexplosive mixture of $6 \%$ hydrogen and $94 \%$ argon is used in the furnace. Multiple equipment and operator errors would have to occur to enable an explosive mixture of hydrogen mixed with air to build up in the box. As a result of the explosion, green pellets are assumed to be subjected to the direct force of the resultant shock waves. Unlike Ref. 3, where the facility layout can accommodate segregation (in effect limiting the explosion damage), it is assumed that the glove boxes involved in powder blending are damaged indirectly by the explosion. It is not expected that the shock wave impacting this area would be severe enough to significantly damage all of the storage inventory because interim storage cans would provide some mitigation.

\subsubsection{Source term}

The split in the material at risk (between green pellets, pellets in the furnace, and powder storage areas) is shown in Table 16 for the $32-\mathrm{kg}$ batch. No specific release fractions are given in the literature for deflagration forces on green pellets that are pressed to $\sim 60 \%$ theoretical density. Reference 5 , Sect. 4.3 .3 , discusses a formulation for determining the product of the airborne release fraction and respirable fraction $(A R F * R F)$ for dropped uranium dioxide pellets. A release fraction (combined ARF*RF) of $1 \times 10^{-4}$ was deemed to be conservative for all material $(40,000 \mathrm{~g})$ in the furnace subjected to explosive forces. This same release and respirable fraction was also used for the green pellets that would be pressed and likely near the furnace. The $80,000 \mathrm{~g}$ of green pellets would be a little further from the blast and in trays or containers. The same release fraction was applied to these green pellets and is thought to be conservative.

The remaining part of the $20-\mathrm{kg}$ batch was assumed to be split between the MOX master blend and powder storage stations. The MOX powder in the blending areas would likely be in a different glove box and somewhat removed from the blast. These glove boxes are assumed to be indirectly damaged from the explosion. As previously stated, most of the storage powder would be in interim cans that would merely be displaced. Powders in a glove box that undergo damage from external explosions are discussed in Ref. 5 (p. 4-69) . A release fraction (and respirable fraction) of $5 \times 10^{3}$ (and 0.3) was used and conservatively applied to all of the powder. The total source term is shown in Table 16. The building confinement is judged to be still intact resulting in a filtered stack release.

\subsubsection{Frequency estimate}

Because no definitive designs for the furnace and glove boxes currently exist, estimation of the probability of this event is difficult at this time. A judgment was made that the frequency of this event is extremely unlikely (between $1 \times 10^{-4} /$ year and $1 \times 10^{-6} /$ year). Such an explosion of sufficient size from the furnace to impact the glove boxes would only be possible because of a combination of equipment failure and human error. 
Table 16. Source term for the evaluation basis explosion

\begin{tabular}{|c|c|c|c|c|c|c|c|c|c|c|c|c|}
\hline $\begin{array}{l}\text { Processing } \\
\text { station }\end{array}$ & $\begin{array}{c}\text { Material at } \\
\text { risk } \\
\text { (g) }\end{array}$ & $\begin{array}{l}\text { Physical } \\
\text { form }\end{array}$ & $\begin{array}{l}\text { Damage } \\
\text { ratio }\end{array}$ & $\begin{array}{l}\text { Airborne } \\
\text { release } \\
\text { fraction }\end{array}$ & $\begin{array}{l}\text { Respirable } \\
\text { fraction }\end{array}$ & $\begin{array}{l}\text { Leak-path } \\
\text { factor }\end{array}$ & $\begin{array}{l}{ }^{238} \mathrm{Pu} \\
\text { released }\end{array}$ & $\begin{array}{l}{ }^{239} \mathrm{Pu} \\
\text { released }\end{array}$ & $\begin{array}{l}240 \mathrm{Pu} \\
\text { released }\end{array}$ & $\begin{array}{l}{ }^{241} \mathrm{Pu} \\
\text { released }\end{array}$ & $\begin{array}{l}{ }^{242} \mathrm{Pu} \\
\text { released }\end{array}$ & $\begin{array}{l}{ }^{241} \mathrm{Am} \\
\text { released }\end{array}$ \\
\hline $\begin{array}{l}\text { Master mix } \\
\text { powder storage }\end{array}$ & 33,000 & $\begin{array}{l}\text { Fine powder } \\
\text { MOX ( } 30 \% \\
\text { blend) }\end{array}$ & 1.00 & $5.00 \times 10^{-3}$ & 0.3 & $1.00 \times 10^{-5}$ & $6.73 \times 10^{-7}$ & $7.49 \times 10^{-6}$ & $1.92 \times 10^{-6}$ & $6.75 \times 10^{-6}$ & $5.14 \times 10^{-10}$ & $4.04 \times 10^{-6}$ \\
\hline $\begin{array}{l}\text { MOX blend } \\
\text { storage }\end{array}$ & 100,000 & $\begin{array}{l}\text { Fine powder } \\
\text { MOX (10\% } \\
\text { blend) }\end{array}$ & 1.00 & $5.00 \times 10^{-3}$ & 0.3 & $1.00 \times 10^{-5}$ & $6.79 \times 10^{-7}$ & $7.57 \times 10^{-6}$ & $1.94 \times 10^{-6}$ & $6.81 \times 10^{-6}$ & $5.19 \times 10^{-10}$ & $4.08 \times 10^{-6}$ \\
\hline $\begin{array}{l}\text { MOX green } \\
\text { pellet storage } \\
\text { (in pellet press } \\
\text { area) }\end{array}$ & 80,000 & $\begin{array}{l}\text { Pressed to } 0.6 \\
\text { TD, MOX } \\
\text { (10\% blend) }\end{array}$ & 1.00 & $1.00 \times 10^{-4}$ & 1 & $1.00 \times 10^{-5}$ & $3.62 \times 10^{-8}$ & $4.04 \times 10^{-7}$ & $1.03 \times 10^{-7}$ & $3.63 \times 10^{-7}$ & $2.77 \times 10^{-11}$ & $2.18 \times 10^{-7}$ \\
\hline $\begin{array}{l}\text { Pellet sintering } \\
\text { furnace }\end{array}$ & 40,000 & $\begin{array}{l}\text { Assume all } \\
\text { green pellets } \\
\text { MOX (10\% } \\
\text { blend) }\end{array}$ & 1.00 & $1.00 \times 10^{-4}$ & 1 & $1.00 \times 10^{-5}$ & $1.81 \times 10^{-8}$ & $2.02 \times 10^{-7}$ & $5.17 \times 10^{-8}$ & $1.82 \times 10^{-7}$ & $1.39 \times 10^{-11}$ & $1.09 \times 10^{-7}$ \\
\hline \multicolumn{7}{|c|}{$\begin{array}{l}\text { Total isotopic source term, } \mathrm{Ci} \\
\text { Total source term, } \mathrm{Pu} / \mathrm{Am} \text { mix, } \mathrm{g}\end{array}$} & $1.41 \times 10^{-6}$ & $\begin{array}{l}1.57 \times 10^{-5} \\
2.739 \times 10^{-4} \\
\end{array}$ & $4.02 \times 10^{-6}$ & $1.41 \times 10^{-5}$ & $1.08 \times 10^{-9}$ & $8.45 \times 10^{-6}$ \\
\hline
\end{tabular}




\subsubsection{Beyond-Evaluation Basis Seismic Event}

\subsubsection{Discussion}

In this analysis an event much more severe in consequences than what might be expected to be the design basis (or evaluation basis) is examined. For some existing DOE facilities, the estimated seismic frequency for beyond-design basis events can be greater than $1 \times 10^{-6} /$ year. The design basis for every building in the complex varies considerably depending on site specifics and the type of construction used in the building. A damage assessment of the facility is further complicated by the fact that seismic considerations could also be incorporated in the glove box design of the facility. In reality, such a catastrophic event may or may not demolish the building and/or the glove boxes. However, for the purposes of illustrating a high consequence accident (which occurs at a very low frequency), total demolition of the building has been assumed. In this event, no credit is taken for the building, the filters, or the glove boxes.

\subsubsection{Source term}

In the evaluation basis seismic event previously discussed, credit was taken for the 3013 cans (which have double containment) in the vault storage area. In this event, however, a total building collapse is used, and a judgment was made that a few of the containers may fail. A damage ratio of 0.05 was used; it equates to 4 out of 80 cans in the vault area. For the source term evaluation of the remainder of the in-process material (including the two cans that feed the process), the release fractions were selected to be the same as in the evaluation basis seismic event. However, because it is assumed that the building collapses and the ventilation system is severed, no credit is taken for filtration. This results in a building leak-path factor of 1.0. The source term is assumed to be released at or near ground level $(10 \mathrm{~m})$. Table 17 shows the source term for this event.

\subsubsection{Frequency}

As discussed previously there is great difficulty in assigning a frequency for this event, especially because facilities are not analyzed for very high seismic events that occur with very infrequent return periods. Site specifics make the frequency assessment of this event very uncertain as well. For the sake of this analysis, a frequency value of $1 \times 10^{-6}$ or less is thought to be appropriate for the EIS purposes.

\subsubsection{Beyond-Evaluation Basis Major Building Fire}

\subsubsection{Discussion}

Fuel manufacturing operations do not lend themselves to the use of large significant amounts of combustible material. In this scenario, however, it is assumed that the building is burned for a considerable length of time, resulting in a total collapse of the building. This event could also roughly be characterized as a large fire following a total building collapse.

\subsubsection{Source term}

Some thought was given to the stability of the 3013 cans in the vault which would be subjected to prolonged heat during a large fire. Because of the double containment and high-pressure rating for the cans, it was judged that the cans could withstand a large building fire. However, because a major building fire breaches the confinement, it is assumed that the building structure could collapse. This happens in large buildings subjected to high heat loads for long periods of time. As a result of this consideration, four of the cans in the vault area were assumed to have breached, just as in the beyond-evaluation seismic event. For the two oxide cans in process, it was conservatively assumed that they burst (previously discussed in the evaluation-basis fire scenario). The remainder of the $32-\mathrm{kg}$ inventory was assumed to be subjected to a 
Table 17. Source term for beyond the evaluation basis seismic event (total building collapse assumed)

\begin{tabular}{|c|c|c|c|c|c|c|c|c|c|c|c|c|}
\hline $\begin{array}{l}\text { Processing } \\
\text { station }\end{array}$ & $\begin{array}{c}\text { Material at } \\
\text { risk } \\
\text { (g) }\end{array}$ & $\begin{array}{l}\text { Physical } \\
\text { form }\end{array}$ & $\begin{array}{l}\text { Damage } \\
\text { ratio }\end{array}$ & $\begin{array}{l}\text { Airborne } \\
\text { release } \\
\text { fraction }\end{array}$ & $\begin{array}{l}\text { Respirable } \\
\text { fraction }\end{array}$ & $\begin{array}{l}\text { Leak-path } \\
\text { factor }\end{array}$ & 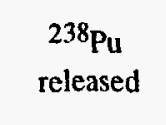 & 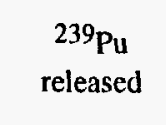 & $\begin{array}{l}240 \mathrm{Pu} \\
\text { released }\end{array}$ & 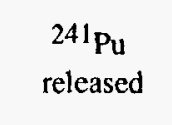 & $\begin{array}{l}{ }^{242} \mathrm{Pu} \\
\text { released }\end{array}$ & $\begin{array}{l}{ }^{24 l} \mathrm{Am} \\
\text { released }\end{array}$ \\
\hline $\begin{array}{l}\text { Plutonium } \\
\text { storage vault }\end{array}$ & 400,000 & $\begin{array}{l}\text { Fine powder } \\
\mathrm{PuO}_{2}\end{array}$ & 0.05 & $1.00 \times 10^{-3}$ & 0.10 & $1.00 \times 10^{0}$ & $9.06 \times 10^{-3}$ & $1.01 \times 10^{-1}$ & $2.59 \times 10^{-2}$ & $9.08 \times 10^{-2}$ & $6.93 \times 10^{-6}$ & $5.44 \times 10^{-2}$ \\
\hline $\begin{array}{l}\text { Plutonium oxide } \\
\text { ( } 2 \text { cans) }\end{array}$ & 10,000 & $\begin{array}{l}\text { Fine powder } \\
\mathrm{PuO}_{2}\end{array}$ & 1.00 & $1.00 \times 10^{-2}$ & 0.20 & $1.00 \times 10^{0}$ & $9.06 \times 10^{-2}$ & $1.01 \times 10^{0}$ & $2.59 \times 10^{-1}$ & $9.08 \times 10^{1}$ & $6.93 \times 10^{-5}$ & $5.44 \times 10^{-1}$ \\
\hline $\begin{array}{l}\text { Master mix } \\
\text { powder storage }\end{array}$ & 53,000 & $\begin{array}{l}\text { Fine powder } \\
\text { MOX ( } 30 \% \\
\text { blend) }\end{array}$ & 1.00 & $1.00 \times 10^{-3}$ & 0.10 & $1.00 \times 10^{0}$ & $7.20 \times 10^{-3}$ & $8.02 \times 10^{-2}$ & $2.06 \times 10^{-2}$ & $7.22 \times 10^{-2}$ & $5.51 \times 10^{-6}$ & $4.33 \times 10^{-2}$ \\
\hline $\begin{array}{l}\text { MOX blend } \\
\text { storage }\end{array}$ & 160,000 & $\begin{array}{l}\text { Fine powder } \\
\text { MOX (10\% } \\
\text { blend) }\end{array}$ & 1.00 & $1.00 \times 10^{-3}$ & 0.10 & $1.00 \times 10^{0}$ & $7.25 \times 10^{-3}$ & $8.07 \times 10^{-2}$ & $2.07 \times 10^{-2}$ & $7.27 \times 10^{-2}$ & $5.54 \times 10^{-6}$ & $4.35 \times 10^{-2}$ \\
\hline \multicolumn{7}{|c|}{ Total isotopic source term, $\mathrm{Ci}$} & $1.14 \times 10^{-1}$ & $1.27 \times 10^{0}$ & $3.26 \times 10^{-1}$ & $1.14 \times 10^{-0}$ & $8.72 \times 10^{-5}$ & $6.85 \times 10^{-1}$ \\
\hline \multicolumn{8}{|c|}{ Total source term, Pu/Am mix, $g$} & 22.22 & & & & \\
\hline
\end{tabular}


release fraction corresponding to falling debris in cans (similar to a seismic event). The total estimated source term is shown in Table 18 . However, because considerable heat is produced by the fire, a significant plume rise would occur. Therefore, a release height of $100 \mathrm{~m}$ was judged to be appropriate for this event.

\subsubsection{Frequency}

Assigning a frequency for this event is difficult because significant combustible loads are not placed in close proximity to the process. This is a very low frequency noncredible event, which requires the introduction of significant combustibles that would create a fire large enough to collapse the structure. For the sake of this analysis, a frequency value of much less than $1 \times 10^{-7}$ is thought to be appropriate for the EIS purposes.

\subsection{EVALUATION OF POTENTIAL CHEMICAL SOURCE TERMS}

Chemical and radiological materials used in this facility were previously given in Table 6 . With respect to radiological effects, the source terms associated with plutonium oxide constitute an overwhelming majority of the radiological risk. With respect to the chemical hazards associated with depleted $\mathrm{UO}_{2}$ (which are released in conjunction with the plutonium oxide in the scenarios outlined in the previous sections), no specific source terms have been generated in this analysis. As discussed in previous sections, only small amounts of plutonium (generally $<1 \mathrm{~g}$ ) constitute the source terms. If treated similarly (from a release standpoint), small amounts of the depleted uranium that may accompany the plutonium oxide that escapes the building are judged to be inconsequential.

Table 6 also gives the other chemicals and compounds that will be used annually by the facility and lists the yearly consumption of gases, liquids, and solids. With respect to any possibly chemical source term, the gases listed (i.e., helium, hydrogen, nitrogen, and oxygen) do not constitute an inhalation or exposure hazard in the context of LA fabrication operations. Reportable quantities of various chemical compounds are cited in 40 CFR 302, Table 262.4. If a chemical company operator spills less than these quantities, the Environmental Protection Agency is not notified. While this is not an absolute criterion that guarantees the lack of off-site consequences, it is illustrative to examine the yearly flow of chemicals based on these reported quantities.

Table 19 compares the annual usage of chemicals to the reportable quantities for that material. While not all materials are listed, the comparison shows that the LA facility does not constitute a major source of chemical inventories. The chemicals listed are either in a liquid or solid form, and the gases listed are not hazardous from an inhalation perspective. Typical occupational chemical exposure incidents, such as acid burns to a worker, are certainly credible. A significant release scenario (inhalation risk, ingestion risk, or skin contact risk) that constitutes a source term (with a magnitude of reasonable concern) to a receptor is difficult to credibly postulate at this stage of the facility analysis. Because of the small size of the facility and the small quantities of chemicals that are expected to be on hand, it is concluded that no chemical source terms are worthy of analysis (that are beyond what is found in small standard industrial facilities). The amounts that would be in use by this facility are certainly considered to be well within the scope of typical industrial hazards found in laboratory environments.

\subsection{SITE SPECIFICS FOR THE LLNL BUILDING 332}

\subsubsection{Stack Release Height}

For Building 332, the stack release height is $\sim 4.6 \mathrm{~m}(\sim 15 \mathrm{ft})$.

\subsubsection{Evaluated Seismic Attributes}

The Plutonium Facility (Building 332) has been determined to be a Hazard Category 2 Facility according to DOE (1992a), which corresponds to a Moderate Hazard Usage Category according to Kennedy (1990). The facility contains PC 3 SSCs. For PC 3 and a Hazard Category 2 facility, 
Table 18. Source term for beyond the evaluation basis major building fire/building collapse (total building collapse assumed to result; source term release height $=100 \mathrm{~m}$ )

\begin{tabular}{|c|c|c|c|c|c|c|c|c|c|c|c|c|}
\hline $\begin{array}{l}\text { Processing } \\
\text { station }\end{array}$ & $\begin{array}{c}\text { Material at } \\
\text { risk } \\
\text { (g) }\end{array}$ & $\begin{array}{l}\text { Physical } \\
\text { form }\end{array}$ & $\begin{array}{l}\text { Damage } \\
\text { ratio }\end{array}$ & $\begin{array}{l}\text { Airborne } \\
\text { release } \\
\text { fraction }\end{array}$ & $\begin{array}{l}\text { Respirable } \\
\text { fraction }\end{array}$ & $\begin{array}{l}\text { Leak-path } \\
\text { factor }\end{array}$ & ${ }^{238} \mathrm{Pu}$ & ${ }^{239} \mathrm{Pu}$ & $\begin{array}{l}240 \mathrm{Pu} \\
\text { released }\end{array}$ & $\begin{array}{l}{ }^{241} \mathrm{Pu} \\
\text { released }\end{array}$ & $\begin{array}{l}242 \mathrm{Pu} \\
\text { released }\end{array}$ & $\begin{array}{l}{ }^{241} \mathrm{Am} \\
\text { released }\end{array}$ \\
\hline $\begin{array}{l}\text { Plutonium } \\
\text { storage vault }\end{array}$ & 400,000 & $\begin{array}{l}\text { Fine powder } \\
\mathrm{PuO}_{2}\end{array}$ & 0.05 & $1.00 \times 10^{-3}$ & 0.10 & $1.00 \times 10^{0}$ & $9.06 \times 10^{-3}$ & $1.01 \times 10^{-1}$ & $2.59 \times 10^{-2}$ & $9.08 \times 10^{-2}$ & $6.93 \times 10^{-6}$ & $5.44 \times 10^{-2}$ \\
\hline $\begin{array}{l}\text { Plutonium oxide } \\
\text { ( } 2 \text { cans) }\end{array}$ & 10,000 & $\begin{array}{l}\text { Fine powder } \\
\mathrm{PuO}_{2}\end{array}$ & 0.10 & $1.00 \times 10^{-1}$ & 0.70 & $1.00 \times 10^{0}$ & $3.17 \times 10^{-1}$ & $3.53 \times 10^{0}$ & $9.05 \times 10^{-1}$ & $3.18 \times 10^{0}$ & $2.42 \times 10^{-4}$ & $1.90 \times 10^{0}$ \\
\hline $\begin{array}{l}\text { Master mix } \\
\text { powder storage }\end{array}$ & 53,000 & $\begin{array}{l}\text { Fine powder } \\
\text { MOX (30\% } \\
\text { blend) }\end{array}$ & 1.00 & $1.00 \times 10^{-3}$ & 0.10 & $1.00 \times 10^{0}$ & $7.20 \times 10^{-3}$ & $8.02 \times 10^{-2}$ & $2.06 \times 10^{-2}$ & $7.22 \times 10^{-2}$ & $5.51 \times 10^{-6}$ & $4.33 \times 10^{-2}$ \\
\hline $\begin{array}{l}\text { MOX blend } \\
\text { storage }\end{array}$ & 160,000 & $\begin{array}{l}\text { Fine powder } \\
\text { MOX }(10 \% \\
\text { blend })\end{array}$ & 1.00 & $1.00 \times 10^{-3}$ & 0.10 & $1.00 \times 10^{0}$ & $7.25 \times 10^{-3}$ & $8.07 \times 10^{-2}$ & $2.07 \times 10^{-2}$ & $7.27 \times 10^{-2}$ & $5.54 \times 10^{-6}$ & $4.35 \times 10^{-2}$ \\
\hline \multicolumn{7}{|c|}{$\begin{array}{l}\text { Total isotopic source term, } \mathrm{Ci} \\
\text { Total source term, } \mathrm{Pu} / \mathrm{Am} \text { mix, } \mathrm{g}\end{array}$} & $3.41 \times 10^{-1}$ & $\begin{array}{l}3.79 \times 10^{0} \\
66.32\end{array}$ & $9.72 \times 10^{-1}$ & $3.42 \times 10^{0}$ & $2.60 \times 10^{-4}$ & $2.05 \times 10^{0}$ \\
\hline
\end{tabular}


Table 19. Comparison of LA facility annual usage and reportable quantity per 40 CFR 302

\begin{tabular}{lcl}
\hline \multicolumn{1}{c}{ Item } & $\begin{array}{c}\text { Annual average } \\
\text { consumption }\end{array}$ & $\begin{array}{c}\text { Reportable } \\
\text { quantity }\end{array}$ \\
\hline Liquids & $1 \mathrm{lb}$ & $5,000 \mathrm{lb}$ \\
Hydrochloric acid & $2 \mathrm{lb}$ & $1,000 \mathrm{lb}$ \\
Nitric acid & $<45 \mathrm{lb}$ & Not listed \\
Polyethylene glycol & $5 \mathrm{lb}$ & $1,000 \mathrm{lb}$ \\
Sulfuric acid & $34 \mathrm{lb}$ & $1,000 \mathrm{lb}$ \\
Solids & $<200 \mathrm{lb}$ & Not listed \\
Sodium hydroxide & $<45 \mathrm{lb}$ & Not listed \\
Sodium nitrate & & \\
Zinc stearate & $60 \mathrm{gal}$ & Not listed \\
Nonprocess chemicals & $10 \mathrm{lb}$ & Not listed \\
Alcohol & $60 \mathrm{gal}$ & Not listed \\
Hydraulic fluid & & \\
General cleaning fluids & &
\end{tabular}

the effective peak ground acceleration of $0.57 \mathrm{~g}$, with a return period of 1,000 years, is listed in Table C-5b of DOE-STD-1020 (DOE 1994c). The effective peak ground acceleration of $0.57 \mathrm{~g}$ (applying to both horizontal and vertical directions simultaneously is used as the EBE. The structural framing criteria for Building 334 for earthquake criteria (Moderate Hazard) are as follows: (1) Design for a DBE with a $0.25 \mathrm{~g}$ horizontal PGA acting simultaneously using UBC material strength allowable. Building connections shall be designed for an additional load factor of 1.5 times the earthquake forces resulting from the $0.25 \mathrm{~g} \mathrm{DBE}$ (horizontal + vertical). (2) Design for a DBE with a $0.50 \mathrm{~g}$ horizontal PGA applied simultaneously with a vertical PGA of $\pm 0.33 \mathrm{~g}$. For this level of DBE, the building structure must remain intact during and after the earthquake.

This estimate does not consider the equipment specifics that would be involved in the MOX LA fabrication line and represents an estimate for the building and confinement-related ventilation system. Cross-comparisons of frequencies and evaluation basis values for sites must be performed with caution. Such simple comparisons do not take into account the differences in analytical approaches that were used at each site to estimate the building response, acceleration, or estimated frequency for the site. As a general rule for all sites, it is expected that the evaluation basis frequency for a seismic event would be from $1 \times 10^{-2} /$ year to $1 \times 10^{-4} /$ year, and likely between $1 \times 10^{-3} /$ year and $1 \times 10^{-4} /$ year. 
Page Intentionally Blank 


\section{TRANSPORTATION}

\subsection{OPERATIONS-RELATED TRANSPORTATION REQUIREMENTS}

Production of MOX fuel LAs, irradiation of the LAs in commercial reactors, and subsequent PIE will result in a number of packaging and transportation operations to (1) obtain the necessary feed materials to manufacture LAs, (2) package and transport the completed fuel assemblies from the fabrication facility to the commercial reactor, and (3) package and transport the irradiated fuel assemblies from the commercial reactor to another facility for PIE.

Plans for MOX fuel LA testing involve manufacture of up to ten MOX fuel LAs, with up to eight LAs undergoing irradiation while the remaining LAs are maintained as unirradiated archives. Each LA could contain from as few as one-third MOX rods (with the balance of the rods being LEU) to an entire assembly composed of MOX rods. Under these circumstances, production of LA will require that LEU and MOX fuel rods be combined in a single assembly. This activity could occur at either the LA fabrication facility or at the reactor facility. While reactors generally have the ability to substitute individual rods within an assembly (due to detected damage), it is expected that exchanging as many as one-third of the LEU assembly rods with MOX rods would occur at the LA facility.

\subsubsection{Feed Materials}

Table 20 provides information about the shipment of $\mathrm{PuO}_{2}$. Table 21 provides information about the shipment of depleted $\mathrm{UO}_{2}$. Depleted $\mathrm{UO}_{2}$ can be obtained by the consortium, or DOE will provide either depleted uranium fluoride $\left(\mathrm{DUF}_{6}\right)$ or depleted uranium oxide $\left(\mathrm{DUO}_{3}\right)$ for conversion by the consortium. Other materials (e.g., new empty fuel rods, end plugs, grid spacers, and other assembly hardware) are not "regulated" materials for transportation. Their shipment would not require special packaging, other than to protect the economic value of the commodity. The specific LA design is uncertain. Some designs may have every fuel rod contain MOX, while other designs may have both $\mathrm{MOX}$ and $\mathrm{UO}_{2}$ fuel rods within a bundle. In the latter case, it would be necessary to either ship enriched $\mathrm{UO}_{2}$ fuel rods (or $\mathrm{UO}_{2}$ fuel rods in LEU fuel assemblies) to the MOX fabrication facility or to ship MOX fuel rods from the fabrication facility to the commercial fuel fabrication site (for insertion in LEU fuel assemblies shipped separately to the reactor). If the MOX LA will contain a large fraction of MOX rods (one-third or more), it is expected that the LA facility will need to receive LEU fuel assemblies (possibly, with unfilled rod positions) from a commercial fuel vendor. The LA fuel facility would then place MOX rods within the assembly and package the MOX LA for shipment to the reactor. Table 22 provides information on the shipment of LEU fuel assemblies to the MOX LA fuel facility, if needed.

\subsubsection{Fresh MOX Fuel Assemblies}

Table 23 provides information about the transport of fresh (unirradiated) MOX fuel from the fabrication facility to the commercial reactor, while Table 24 provides the fresh MOX fuel isotopic contents. The same package identified for shipment of the MOX fuel assemblies (the MO-1) would also be used to ship groups of individual MOX fuel rods to a commercial fuel fabrication site for insertion in a MOX fuel bundle if this approach is used.

\subsubsection{Spent MOX Fuel Assemblies}

Tables 25 and 26 provide information about the transport of spent (irradiated) MOX fuel from the commercial reactor to the PIE facility. Table 27 provides information regarding existing casks that could be used to transport spent MOX fuel to the PIE facility. The number of shipments of spent MOX fuel will depend on the actual plans for LA irradiation and plans for subsequent PIE. Based on the schedule described in Fig. 2, up to eight shipments of LA spent fuel could be transported between the reactor and the PIE facility. 
Table 20. Transportation of $\mathrm{PuO}_{2}$ to support $\mathrm{LA}$ fabrication

Number of shipments to LA fabrication site ${ }^{a}$

1 or more

Assuming $321 \mathrm{~kg} \mathrm{HM}$ as $\mathrm{PuO}_{2}$ is needed for startup and to produce $10 \mathrm{LTAs}$

Would require about 73 packages ( $4.4 \mathrm{~kg} \mathrm{HM} /$ package). SST could accommodate

30 to 35 packages per trailer. Single SST convoy (three trailers) could deliver entire $\mathrm{PuO}_{2}$ supply for LTA campaign.

Container types used for shipments

Availability of containers

Likely candidate package would be 9968 or 9975 , perhaps SAFKEG

Only 9968 is currently certified

Average shipping container weight

Average material weight loaded into container

Average isotopic contents

Average exposure rate at $1 \mathrm{~m}$

Maximum anticipated dose rate at $1 \mathrm{~m}$

Type B

Yes

Will need to be determined

Regulatory limits are $200 \mathrm{mrem} / \mathrm{h}$ at surface of package $(1000 \mathrm{mrem} / \mathrm{h}$ for closed transport vehicles, exclusive use, cargo secured); $200 \mathrm{mrem} / \mathrm{h}$ (outer surface of vehicle); $10 \mathrm{mrem} / \mathrm{h}$ at point $2 \mathrm{~m}$ from package surface; and $2 \mathrm{mrem} / \mathrm{h}$ (in occupied spaces) (i.e., crew cab, etc.)

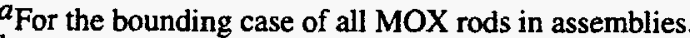

$b_{\text {See Table } 24 .}$

Table 21. Transportation of depleted $\mathrm{UO}_{2}$ to support $\mathrm{LA}$ fabrication ${ }^{a, b}$

Number of shipments to LA fabrication site

$\mathrm{UO}_{2}$ is shipped in standard metal drums

Truck could accommodate 40,000 lb ( -72 drums)

Mission would only require about 28 drums $\mathrm{UO}_{2}$

Container types used for shipments

A strong-tight container (open head 55-gal drum)

Probably use UN1A2 (steel drum)

Availability of containers

Average shipping container weight, $\mathrm{kg}$ (lb)

Average material weight loaded into container

Average isotopic contents

Average exposure rate at $1 \mathrm{~m}$

Maximum anticipated dose rate at $1 \mathrm{~m}$

Will need to be determined

Regulatory limits are $200 \mathrm{mrem} / \mathrm{h}$ at surface of package

(1000 $\mathrm{mrem} / \mathrm{h}$ for closed transport vehicles, exclusive use, cargo secured);

$200 \mathrm{mrem} / \mathrm{h}$ (outer surface of vehicle); $10 \mathrm{mrem} / \mathrm{h}$ at point $2 \mathrm{~m}$ from package

surface; and $2 \mathrm{mrem} / \mathrm{h}$ (in occupied spaces) (i.e., crew cab, etc.)

$a_{\text {See Ref. }} 2$ for more information on depleted uranium. Refer to Table 24 for uranium isotopic content.

$b_{\text {Unlike }} \mathrm{UF}_{6}$ cylinders, depleted $\mathrm{UO}_{2}$ is purified, with daughter products removed that result in potential doses. 
Table 22. Transportation of materials to support LA fabrication (LEU fuel assemblies)

Number of shipments of LA fabrication site 1

Assuming that all 10 LEU assemblies could be shipped on a single commercial vehicle (just as LEU fuel is shipped currently). Would require use of $5 \mathrm{LEU}$ fuel packages.

Container types used for shipments

Availability of containers

Average shipping container weight, $\mathrm{kg}(\mathrm{lb})$

Average material weight loaded into container

Average isotopic contents

Average exposure rate at $1 \mathrm{~m}, \mathrm{mR} / \mathrm{h}$

Maximum anticipated dose rate at $1 \mathrm{~m}, \mathrm{mR} / \mathrm{h}$

Will need to be determined

Regulatory limits are $200 \mathrm{mrem} / \mathrm{h}$ at surface of package $(1000 \mathrm{mrem} / \mathrm{h}$ for closed transport vehicles, exclusive use, cargo secured); $200 \mathrm{mrem} / \mathrm{h}$ (outer surface of vehicle); $10 \mathrm{mrem} / \mathrm{h}$ at point $2 \mathrm{~m}$ from package surface; and $2 \mathrm{mrem} / \mathrm{h}$ (in occupied spaces) (i.e., crew cab, etc.)

Table 23. Transportation of LAs to generic reactor site

Number of SST shipments of LAs to generic reactor Assuming two shipments (four assemblies) each, to two different reactors, with two additional assemblies archived

Type of containers used for shipments

Likely candidate is the MO-1, USA/9069/B

Potential problems-NRC may require additional analysis to continue inclusion of MOX contents on package certificate. Also, MO-1 certificate lists $85 \%$ fissile plutonium in total plutonium. WG MOX would be $\sim 94 \%$, so additional analysis is needed to ensure that LTAs can be transported in MO-1 (may need to enhance criticality controls)

No package currently available in the United States for boiling-water reactor (BWR) MOX assemblies; probably could amend MO-1 certificate to allow two BWR assemblies

Availability of containers

Average shipping container weight

Gross weight, including two pressurized-water reactor (PWR) fuel assemblies

Average material weight loaded into shipping container

Average isotopic content (by isotope, mass \% content)

Average exposure rate at $1 \mathrm{~m}$

Will need to be determined, both for worker doses as well as transportation risk assessment

Should be fairly low

Maximum anticipated dose rate at $1 \mathrm{~m}$

Will need to be determined

Regulatory limits are $200 \mathrm{mrem} / \mathrm{h}$ at surface of package $(1000 \mathrm{mrem} / \mathrm{h}$ for closed transport vehicles, exclusive use, cargo secured); $200 \mathrm{mrem} / \mathrm{h}$ (outer surface of vehicle); $10 \mathrm{mrem} / \mathrm{h}$ at point $2 \mathrm{~m}$ from package surface; and $2 \mathrm{mrem} / \mathrm{h}$ (in occupied spaces) (i.e., crew cab, etc.)

$a^{a}$ See Table 24.

Only two MO-1

packages exist

$3900 \mathrm{~kg}(8600 \mathrm{lb})$

$\sim 1400 \mathrm{~kg}(3000 \mathrm{lb})$

$a$

$0.1 \mathrm{mrem} / \mathrm{h}$

$10 \mathrm{mrem} / \mathrm{h}$ 
Table 24. Fresh MOX fuel isotopic content $t^{a}$

\begin{tabular}{cc}
\hline $\begin{array}{c}\text { Average isotopic content } \\
(\%)\end{array}$ & $\begin{array}{c}\text { Mass content } \\
(\%)\end{array}$ \\
\hline $235 \mathrm{U}, 0.2$ & 0.1915 \\
$238 \mathrm{U}, 99.8$ & 95.556 \\
$236 \mathrm{Pu},<1 \mathrm{ppb}$ & - \\
$238 \mathrm{Pu}, 0.03$ & 0.00053 \\
$239 \mathrm{Pu}, 92.44$ & 3.995 \\
$240 \mathrm{Pu}, 6.47$ & 0.2485 \\
$241 \mathrm{Pu}, 0.05$ & 0.00592 \\
$242 \mathrm{Pu}, 0.1$ & 0.00249 \\
${ }^{241} \mathrm{Am}, 0.9$ & 0.004 \\
\hline
\end{tabular}

$a_{\text {Source: Ref. } 1 .}$

Note; MOX fuel will be produced with various plutonium concentrations depending on the mission reactors.

Table 25. Transportation of irradiated LAs to PIE site

Number of shipments of irradiated LAs to PIE site

Depending on cask selection, see Table 27

Types of container used for shipments

Availability of shipping containers

Several available choices dependent on previous commitments, ability of facilities to handle particular packages

Possible choices-NAC-LWT or NLI. Each would hold one PWR or two BWR assemblies

Average shipping container weight

Average material weight

Average isotopic content

Uranium, transuranics, fission products (dependent on burnup and decay time)

Average exposure rate at $1 \mathrm{~m}(\mathrm{mrem} / \mathrm{h})$ dependent on burnup and decay time

Maximum anticipated dose rate at $1 \mathrm{~m}$

Dependent on fuel burnup and decay plus selection of package

Must be below regulatory limits
Up to 8

Type B

Yes

\section{$25-40$ tons}

$700-2100 \mathrm{~kg}(1500-4500 \mathrm{lb})$

See Table 26

$-10 \mathrm{mrem} / \mathrm{h}^{a}$

Unknown

${ }^{a}$ Each cask will be loaded to the maximum capacity without exceeding regulatory dose limits. 
Table 26. Spent MOX fuel isotopic content

\begin{tabular}{|c|c|}
\hline Isotope & Mass content ${ }^{a}$ (g/assembly) \\
\hline \multicolumn{2}{|c|}{ Actinides } \\
\hline${ }^{234} \mathrm{U}$ & $1.28 \times 10^{1}$ \\
\hline${ }^{235} \mathrm{U}$ & $3.56 \times 10^{2}$ \\
\hline${ }^{236} \mathrm{U}$ & $1.13 \times 10^{2}$ \\
\hline${ }^{238} \mathrm{U}$ & $4.25 \times 10^{5}$ \\
\hline${ }^{237} \mathrm{~Np}$ & $8.42 \times 10^{1}$ \\
\hline $238 \mathrm{Pu}$ & $9.70 \times 10^{1}$ \\
\hline${ }^{239} \mathrm{Pu}$ & $6.99 \times 10^{3}$ \\
\hline $240 \mathrm{Pu}$ & $4.06 \times 10^{3}$ \\
\hline${ }^{241} \mathrm{Pu}$ & $1.49 \times 10^{3}$ \\
\hline${ }^{242} \mathrm{Pu}$ & $7.50 \times 10^{2}$ \\
\hline${ }^{241} \mathrm{Am}$ & $1.04 \times 10^{3}$ \\
\hline${ }^{242} \mathrm{Am}$ & $3.22 \times 10^{0}$ \\
\hline${ }^{243} \mathrm{Am}$ & $2.03 \times 10^{2}$ \\
\hline${ }^{242} \mathrm{Cm}$ & $8.39 \times 10^{-3}$ \\
\hline${ }^{243} \mathrm{Cm}$ & $8.73 \times 10^{-1}$ \\
\hline${ }^{244} \mathrm{Cm}$ & $5.38 \times 10^{1}$ \\
\hline${ }^{245} \mathrm{Cm}$ & $5.40 \times 10^{0}$ \\
\hline \multicolumn{2}{|c|}{ Fission products } \\
\hline${ }^{90} \mathrm{Sr}$ & $1.31 \times 10^{2}$ \\
\hline${ }^{106} \mathrm{Ru}$ & $1.77 \times 10^{-1}$ \\
\hline${ }^{126} \mathrm{Sn}$ & $2.22 \times 10^{1}$ \\
\hline${ }^{126} \mathrm{Sb}$ & $1.06 \times 10^{-6}$ \\
\hline${ }^{134} \mathrm{Cs}$ & $2.81 \times 10^{0}$ \\
\hline${ }^{137} \mathrm{Cs}$ & $6.21 \times 10^{2}$ \\
\hline${ }^{144} \mathrm{Ce}$ & $2.21 \times 10^{-2}$ \\
\hline${ }^{147} \mathrm{Pm}$ & $6.71 \times 10^{0}$ \\
\hline${ }^{148} \mathrm{Nd}$ & $2.25 \times 10^{2}$ \\
\hline${ }^{154} \mathrm{Eu}$ & $1.30 \times 10^{1}$ \\
\hline
\end{tabular}

${ }^{a_{S}}$ Spent fuel composition is for MOX containing $4.56 \mathrm{wt} \%$ plutonium at a burnup of $45 \mathrm{GWd} / \mathrm{MT}, 10$ years after discharge. Table includes only most significant isotopes.

Source: Memorandum, B. D. Murphy to R. T. Primm III, "Computational Support to Yucca Mountain Project Environmental Impact Statement Data Call," September 12, 1997. 
Table 27. Examples of casks for LWR spent fuel

\begin{tabular}{|c|c|c|c|c|c|}
\hline Name & Owner & Certification No. & $\begin{array}{l}\text { Gross } \\
\text { weight } \\
\text { (lb) }\end{array}$ & Cavity size & Contents \\
\hline NAC-LWT & $\begin{array}{l}\text { NAC } \\
\text { International, } \\
\text { Norcross, GA }\end{array}$ & USA/9225/B(U)F & 51,200 & $\begin{array}{l}\text { 181-in. long by } 13.4 \text {-in. } \\
\text { diam }\end{array}$ & $\begin{array}{l}1 \text { PWR or } 2 \\
\text { BWR } \\
\text { assemblies }\end{array}$ \\
\hline NLI-1/2 & $\begin{array}{l}\text { NAC } \\
\text { International, } \\
\text { Norcross, GA }\end{array}$ & USA $9010 / B() F$ & 49,250 & $\begin{array}{l}\text { 178-in. long by } 13.4 \text {-in. } \\
\text { diam }\end{array}$ & $\begin{array}{l}1 \text { PWR or } 2 \\
\text { BWR } \\
\text { assemblies }\end{array}$ \\
\hline TN-8L & $\begin{array}{l}\text { Transnuclear, } \\
\text { Hawthorne, NY }\end{array}$ & USA/9015/B( )F & 79,380 & $\begin{array}{l}3 \text { cavities, } \\
9 \text { in. } \times 9 \text { in. } \times 168.5 \text { in. }\end{array}$ & $\begin{array}{l}3 \mathrm{PWR} \\
\text { assemblies }\end{array}$ \\
\hline TN-9 & $\begin{array}{l}\text { Transnuclear, } \\
\text { Hawthorne, NY }\end{array}$ & USA/9016/B( )F & 79,200 & $\begin{array}{l}7 \text { cavities, } \\
-6 \text { in. } \times 6 \text { in } \times 178 \text { in. }\end{array}$ & $\begin{array}{l}7 \mathrm{BWR} \\
\text { assemblies }\end{array}$ \\
\hline
\end{tabular}




\section{QUALITATIVE DECONTAMINATION AND DECOMMISSIONING}

\subsection{INTRODUCTION}

The DOE facilities that will be used in the fabrication of MOX LAs have been used previously in the handling of nuclear materials. Because most of the facilities are contaminated to some degree, the MOX mission should have few incremental effects on the ultimate D\&D of these facilities. The intent of the FMDP is to decontaminate the facilities to levels that would permit unrestrictive further use of the facilities.

\subsection{PROCESS PLAN}

The development of a detailed D\&D plan will be necessary to minimize waste generation. Waste minimization during D\&D begins with the design of the MOX facility as discussed below. During the D\&D phase, waste minimization measures would be similar to those required in the operation of any nuclear contamination zone. This includes reducing the number of items taken into a contamination zone to the minimum necessary to perform the job.

\subsection{D\&D OPERATIONS}

Because plutonium is primarily an alpha emitter, containment of contamination is a principle concern in the design and operation of a MOX plant. The process involves two distinctly different areas concerning contamination: (1) pellet fabrication where dusty powders of plutonium and uranium oxides are handled and (2) the rod and bundle assembly areas where little if any contamination should be present. At least $95 \%$ of the waste that will be generated during $D \& D$ will be from the pellet fabrication area.

In the pellet fabrication area, a principle concern must be containment of the potential contamination from the copious quantities of plutonium and uranium dust that will be generated during operation of the dry processes. To minimize future D\&D costs, the containment of this potential contamination at its source of generation must be considered in the design of the MOX facility. This design should include local filtration at the source with no contamination allowed in the duct systems.

The rod and bundle assembly areas will use about $50 \%$ of the total space in the MOX facility and should be relatively contamination free. This space could be returned to beneficial occupancy soon after completion of the mission by simply removing the process equipment. Most of the uncontaminated rod and bundle assembly equipment will likely be useful in the full-scale MOX plant and could be shipped to that facility in the future.

Most of the waste generated during D\&D will come from the pellet fabrication area in the disassembly and disposal of contaminated process equipment items and excess glove boxes. The waste generated during $D \& D$, in addition to the contaminated equipment items and glove boxes, will be similar to the waste generated during operation of the MOX plant. This will consist of solid and liquid radioactive waste in similar types and volumes that will be generated during operations. The ratio of TRU to LLW likely will be higher during D\&D from the cleanup of the plutonium contamination in the glove boxes. The emissions during D\&D should be no more than during the operating phase of the LA MOX plant.

Complete decontamination probably will not be possible for most of the glove boxes and contaminated equipment items, and disposal as either LLW or TRU waste will be required. Most of the large equipment items and excess glove boxes likely will be packaged in large B-25 (4ft $\times 4 \mathrm{ft} \times 6 \mathrm{ft})$ metal waste boxes. Size reduction of some equipment items and glove boxes likely will be required to fit within these boxes. The assay of the TRU content in some contaminated equipment items will be difficult to determine because of the difficulty of establishing calibration standards for the assay equipment. Also, the waste acceptance criteria for such "difficult to certify" TRU waste items for WIPP disposal have not been completely resolved by DOE.

The equipment in the rod and bundle assembly areas either will not be contaminated or probably can be decontaminated to clean release standards for unrestricted use. The disposal of this equipment should present no particular problem. 


\section{Page Intentionally Blank}




\section{PIE}

The two sites being considered for the PIE are Argonne National Laboratory-West (ANL-W) and ORNL. The facilities and infrastructure required to complete all PIE activities for the LA program currently exist at both sites. Accommodation of full-length fuel rods is the only modification required at ANL-W or ORNL to process the materials associated with this program. Both sites currently process equivalent materials to those expected in this program, and program activities will be routine.

Table 28 shows the wastes estimated during the LA PIE. Table 29 shows the possible employee radiation doses involved during PIEs of the LAs, and Table 30 lists the estimated PIEs for the EIS.

Figure 13 shows the location of Building 3525 on the ORNL site, and Fig. 14 shows the location of Building 785 on the ANL-W site. These buildings could be used to perform all PIE activities.

\subsection{PIE DISCUSSION}

PIE begins by shipping either the fuel assembly or the individual rods to the PIE facility. Shipment of selected individual rods is desired as it eliminates a handling step at the PIE facility (disassembly of the fuel assembly) and reduces the amount of irradiated fuel that needs to be handled (because only a fraction of the rods in a bundle is examined), stored, and disposed of at the hot cell.

Once the rods are in the hot cell at the PIE facility they are first subjected to a nondestructive examination. The degree of examination varies, but typically the rods are visually examined for signs of damage or wear, their length and diameter is measured, and individual rods may be weighed. After this simple check, additional examinations include eddy current or ultrasonic testing to locate cracks or flaws; leak testing to determine gas containment; gamma scanning to determine the internal fuel rod integrity, migration of fission products, and burnup; neutron radiography and $\mathrm{X}$-ray radiography to determine the internal physical configuration; and detailed visual examination of any crud or oxide layers on the surface of the clad. The particular techniques employed will depend on the program needs.

After the nondestructive testing has been satisfied, the destructive testing often begins by sampling the fission gas pressure and composition in the rod plenum by puncturing the end of the rod and collecting the gas. The rod may then be cut into segments for fuel examination. Thin sections of the rod are often cut off, mounted in epoxy resin, and polished for metallographic and ceramographic examinations. Additional portions of the fuel rod may be cut up for further fuel and clad examinations. Thin cross sections of the rod may be core drilled for fuel samples and the cores examined by gamma scanning or subjected to radiochemistry examination by dissolution in a chemical solution. The solution may undergo chemical analysis, gamma counting, and/or mass spectrometry for the determination of burnup and fission product composition.

Fuel specimens may undergo density measurements, pore size measurements, thermal diffusivity measurements, specific heat determination, melting point temperature estimation, oxygen to metal ratio measurements, and/or fission gas diffusivity depending on the degree of the investigation and the equipment available.

The rod cross sections may also be mounted in special mounts for examination by microprobe, optical microscope, transmission electron microscopy, and/or scanning electron microscope. Other techniques such as X-ray fluorescence and emission spectroscopy may be used depending on the needs of the investigation. These techniques allow the experimenter to determine the amounts and distribution of fission products, plutonium, uranium, and some trace elements. Such analyses allow the experimenter to compare the results of the irradiation with predictions and to investigate fuel behavior in considerable detail.

Clad specimens for mechanical testing may be prepared by segmenting the fuel rod and sliding the fuel out if possible, drilling the fuel out, or cutting and peeling the clad from the fuel. Once prepared, the clad may be subjected to a wide variety of tests such as tensile testing, burst testing, hardness testing, ductility testing, creep tests, fatigue testing, and chemical surface analysis.

All of these tests are considered to be normal PIE practices. The scope of the required equipment can be as simple as a small numbered scale to complex expensive shielded special purpose microscopes. Two references for PIE work are the Guidebook on Non-Destructive Examination of Water Reactor Fuel, IAEA 
Table 28. Estimated waste generated during the LA PIE

\begin{tabular}{|c|c|c|c|c|}
\hline Waste category & Annual volume & $\begin{array}{l}\text { Total estimated volume } \\
\text { (based on } 4 \text { years) }\end{array}$ & $\begin{array}{l}\text { Waste description } \\
\text { (e.g., glove box gloves, cleaning } \\
\text { solvent, paper wipes) }\end{array}$ & $\begin{array}{l}\text { Anticipated treatment and/or } \\
\text { disposal method (e.g., } \\
\text { solidification) } \\
\text { (specify on-site or off-site) }\end{array}$ \\
\hline $\begin{array}{l}\text { TRU } \\
\text { Liquid } \\
\text { Solid }\end{array}$ & $\begin{array}{l}107 \mathrm{~L}(28.2 \mathrm{gal}) \\
2.6 \mathrm{~m}^{3}\left(91.8 \mathrm{ft}^{3}\right)\end{array}$ & $\begin{array}{l}427 \mathrm{~L}(112.8 \mathrm{gal}) \\
10.4 \mathrm{~m}^{3}\left(367.3 \mathrm{ft}^{3}\right)\end{array}$ & $\begin{array}{l}\text { Paper wipes, plastic, glassware, metal } \\
\text { containers, fuel debris, clad pieces, } \\
\text { radiochemical solutions }\end{array}$ & $\begin{array}{l}\text { Solid material packaged in drums } \\
\text { for shipment to WIPP; liquids } \\
\text { processed on-site for later off-site } \\
\text { disposal as LLW }\end{array}$ \\
\hline $\begin{array}{l}\text { Mixed TRU } \\
\text { Liquid } \\
\text { Solid }\end{array}$ & $\begin{array}{l}1.08 \mathrm{~L}(0.29 \mathrm{gal}) \\
0.03 \mathrm{~m}^{3}\left(0.883 \mathrm{ft}^{3}\right)\end{array}$ & $\begin{array}{l}4.3 \mathrm{~L}(1.16 \mathrm{gal}) \\
0.1 \mathrm{~m}^{3}\left(3.53 \mathrm{ft}^{3}\right)\end{array}$ & $\begin{array}{l}\text { Oils, solvents, and lead shielding con- } \\
\text { taminated with TRU materials. }\end{array}$ & $\begin{array}{l}\text { Solid material will be packaged in } \\
\text { drums for shipment to WIPP; liq- } \\
\text { uids will be processed on-site for } \\
\text { later off-site disposal as LLW }\end{array}$ \\
\hline $\begin{array}{l}\text { LLWa } \\
\text { Liquid } \\
\text { Solid }\end{array}$ & $\begin{array}{l}107 \mathrm{~L}(28.2 \mathrm{gal}) \\
35 \mathrm{~m}^{3}\left(1236 \mathrm{ft}^{3}\right)\end{array}$ & $\begin{array}{l}427 \mathrm{~L}(112.8 \mathrm{gal}) \\
140 \mathrm{~m}^{3}\left(4944 \mathrm{ft}^{3}\right)\end{array}$ & $\begin{array}{l}\text { Paper wipes, plastic, glassware, metal } \\
\text { containers, clad pieces, equipment }\end{array}$ & $\begin{array}{l}\text { Material will be prepared on-site } \\
\text { for shipment to off-site facility }\end{array}$ \\
\hline $\begin{array}{l}\text { Mixed LLW } \\
\text { Liquid } \\
\text { Solid }\end{array}$ & $\begin{array}{l}1.08 \mathrm{~L} \mathrm{(0.29} \mathrm{gal}) \\
0.35 \mathrm{~m}^{3}\left(12.36 \mathrm{ft}^{3}\right)\end{array}$ & $\begin{array}{l}4.3 \mathrm{~L}(1.16 \mathrm{gal}) \\
1.4 \mathrm{~m}^{3}\left(49.4 \mathrm{ft}^{3}\right)\end{array}$ & $\begin{array}{l}\text { Oils, solvents, and lead shielding con- } \\
\text { taminated with fission products } \\
\text { materials }\end{array}$ & $\begin{array}{l}\text { Material will be sorted and pre- } \\
\text { pared on-site for shipment to off- } \\
\text { site facilities }\end{array}$ \\
\hline $\begin{array}{l}\text { Hazardous } c \\
\text { Liquid } \\
\text { Solid }\end{array}$ & $\begin{array}{l}1.08 \mathrm{~L}(0.29 \mathrm{gal}) \\
0.35 \mathrm{~m}^{3}\left(12.36 \mathrm{ft}^{3}\right)\end{array}$ & $\begin{array}{l}4.3 \mathrm{~L}(1.16 \text { gal }) \\
1.4 \mathrm{~m}^{3}\left(49.4 \mathrm{ft}^{3}\right)\end{array}$ & $\begin{array}{l}\text { Used oils, solvents, resins, glues, } \\
\text { containers }\end{array}$ & $\begin{array}{l}\text { Material will be sorted and pre- } \\
\text { pared on-site for shipment to off- } \\
\text { site facilities }\end{array}$ \\
\hline $\begin{array}{l}\text { Nonhazardous (sanitary) } \\
\text { Liquid } \\
\text { Solid }\end{array}$ & $\begin{array}{l}3.79 \times 10^{5} \mathrm{~L}\left(1.0 \times 10^{5} \mathrm{gal}\right) \\
50 \mathrm{~m}^{3}\left(1765 \mathrm{ft}^{3}\right)\end{array}$ & $\begin{array}{l}1.51 \times 10^{6} \mathrm{~L}\left(4 \times 10^{5} \mathrm{gal}\right) \\
130 \mathrm{~m}^{3}\left(4591 \mathrm{ft}^{3}\right)\end{array}$ & $\begin{array}{l}\text { Potable water, cleaning, paper, plastic, } \\
\text { metal containers, garbage }\end{array}$ & $\begin{array}{l}\text { Materials will be disposed of } \\
\text { through laboratory (on-site) non- } \\
\text { hazardous waste facility }\end{array}$ \\
\hline $\begin{array}{l}\text { Nonhazardous (other) } \\
\text { specific by waste } \\
\text { Liquid } \\
\text { Solid }\end{array}$ & $\begin{array}{l}4 \mathrm{~L}(1.06 \mathrm{gal}) \\
0.75 \mathrm{~m}^{3}\left(26.48 \mathrm{ft}^{3}\right)\end{array}$ & $\begin{array}{l}16 \mathrm{~L}(4.23 \mathrm{gal}) \\
3 \mathrm{~m}^{3}\left(106 \mathrm{ft}^{3}\right)\end{array}$ & $\begin{array}{l}\text { Chemical reagents, oils, cleaners, scrap } \\
\text { metal, wood, plastic }\end{array}$ & $\begin{array}{l}\text { Materials will be disposed through } \\
\text { laboratory (on-site) nonhazardous } \\
\text { waste facility. Scrap may be dis- } \\
\text { posed of through the laboratory to } \\
\text { off-site vendors }\end{array}$ \\
\hline
\end{tabular}

Note: Estimates are based on historical experience from other programs and current operations. The actual waste stream will be strongly dependent on the type and amount of work performed. The actual waste handling will depend on the laboratory facilities in operation at the time and the current disposal regulations. The final volumes of waste will be smalter depending on the treatment option (drying, compacting, burning).

$a_{\text {Liquid LLW is assumed to be } 100 \% \text { of the TRU. }}$

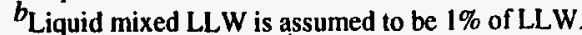

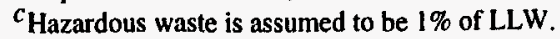


Table 29. Radiation doses to involved workers during the LA PIE [whole body committed effective dose equivalent (CEDE)]

Average annual dose to all involved workers at the facility, mrem 177

Maximum dose to an involved worker at the facility, mrem 347

Total number of involved workers

Note: Table numbers are averages over 1994, 1995, and 1996. for Building 3525

at ORNL. Values are from the radiation protection representative. It is assumed that the MOX PIE will encounter similar exposures.

Table 30. PIE estimates for EIS

For planning purposes assume 17 by 17 fuel bundle array Bundle length

Pellet size

Approximate density $\mathrm{UO}_{2}+\mathrm{PuO}_{2}$

Mass of pellet

Mass of pellet HM

Pellets per rod

Pellet mass per rod

HM per rod

Assume detailed PIE will involve ten rods per bundle and ten bundles

Estimated samples per rod

Total samples.

Assume one-third metal mounts

Assume one-third clad specimens

Assume one-third radiochemical specimens

Liquid waste per metal mount

Liquid waste per clad specimen

Liquid waste per radiochemical specimens

Total specimen liquid waste (TRU)

Solid waste per metal mount and all mounts

Solid waste per clad specimen and all clad specimens

Solid waste per radiochemical specimen and all specimens

Total specimen solid waste (TRU)

Assume two B-25 boxes of equipment

One-half equipment LLW

One-half equipment TRU

Assume one B-25 box per month/48 months

0.9 LLW [personal protective equipment (PPE), wipes. scrap, etc.]

0.1 TRU

Total liquid TRU waste

Total solid TRU waste
289 rods total

$13.50 \mathrm{ft}$

0.37-in. diam,

0.60 -in. length, and

0.06 -in. ${ }^{3}$ volume

$11.00 \mathrm{~g} / \mathrm{cm}^{3}$

$11.43 \mathrm{~g}$

$10.08 \mathrm{~g}$

270.00

$3087 \mathrm{~g}$

$2721 \mathrm{~g}$

100 rods to be cut up

10

1000

333

333

333

$0.5 \mathrm{~L} \quad 167 \mathrm{~L}$ total for metal mounts

$0.1 \mathrm{~L} \quad 33 \mathrm{~L}$ total for clad specimen

$1 \mathrm{~L} \quad 33 \mathrm{~L}$ total for radiochemical

$533 \mathrm{~L}$

$200 \mathrm{~cm}^{3} \quad 0.07 \mathrm{~m}^{3}$ total

$200 \mathrm{~cm}^{3} \quad 0.07 \mathrm{~m}^{3}$ total

$500 \mathrm{~cm}^{3} \quad 0.17 \mathrm{~m}^{3}$ total

$0.30 \mathrm{~m}^{3}$

$6 \mathrm{~m}^{3}$

$3 \mathrm{~m}^{3}$

$3 \mathrm{~m}^{3}$

$144 \mathrm{~m}^{3}$

$130 \mathrm{~m}^{3}$

$14 \mathrm{~m}^{3}$

$533 \mathrm{~L}$

$18 \mathrm{~m}^{3}$ 
Table 30. (continued)

Total mixed liquid TRU waste

Total mixed solid TRU waste

Total liquid LLW

Total solid LLW

Total mixed liquid LLW

Total mixed solid LLW

Other waste streams

Liquid hazardous waste

Solid hazardous waste

Nonhazardous liquid waste

Nonhazardous solid waste

Nonhazardous liquid other waste-chemicals

Nonhazardous solid other waste-scrap metal, one B-25 box
$5 \mathrm{~L}$ (estimated as $1 \%$ of TRU)

$0.18 \mathrm{~m}^{3}$ (estimated as $1 \%$ of TRU)

$533 \mathrm{~L}$ (estimated same as TRU)

$133 \mathrm{~m}^{3}$

$5 \mathrm{~L}$ (estimated as $1 \%$ of LLW)

$1 \mathrm{~m}^{3}$ (estimated as $1 \%$ of LLW)

$5 \mathrm{~L}$ (estimated as $1 \%$ of LLW)

$1 \mathrm{~m}^{3}$ (estimated as $1 \%$ of LLW)

$533 \mathrm{~L}$ (estimated as $100 \%$ LLW)

$133 \mathrm{~m}^{3}$ (estimated as $100 \%$ of LLW)

$5 \mathrm{~L}$ (estimated as $1 \%$ of LLW)

$3 \mathrm{~m}^{3}$

Assume that bulk of the fuel rods and fuel bundle will be handled as spent nuclear fuel and sent to Idaho National Engineering and Environmental Laboratory 


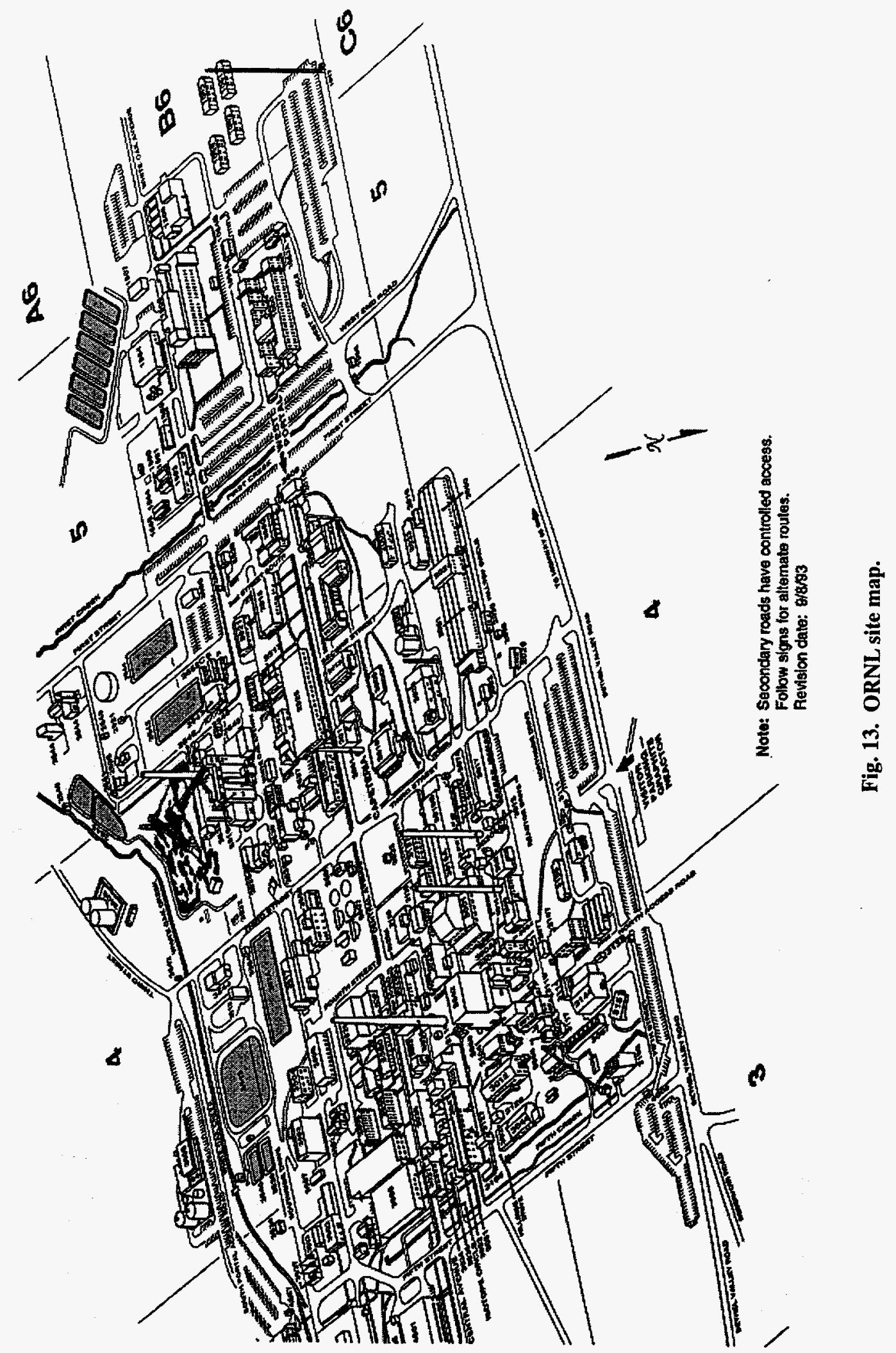


704 Fut Manufacturing Facilty (FMF)

752 Leboratory And OHtice Building (LSO Building)

771 Radioactive Scrap And Waste Facility (RSWF)

775 ZPPR Worksoom-Equipment Room

776 ZPPR Reactor Cell

785 Hot Fuel Examination Facility (HFEF)

797 Radioactive Sodium Storage Facility (RSSF)

798 Radioartive Liquid Waste Treatment Facility (RLWTF)

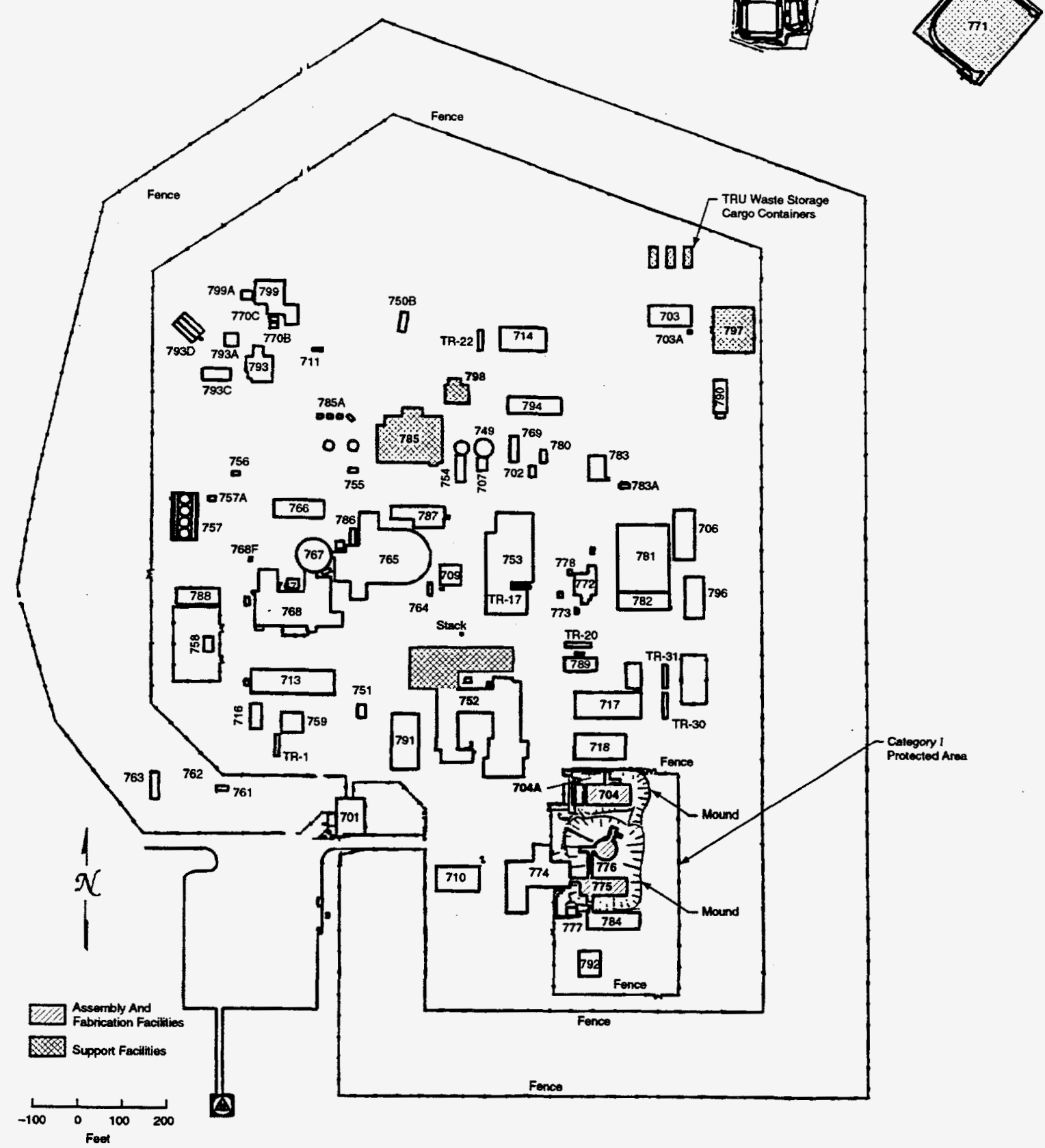

Fig. 14. ANL-W site map. 
Technical Reports Series No. 322; and the Guidebook on Destructive Examination of Water Reactor Fuel, IAEA Technical Reports Series No. 385.

In addition to materials testing, the segmented fuel may be used as a test subject for accident testing. The segment may be heated to high temperatures in a variety of atmospheres in a complex test apparatus and its releases measured. Other specialized methods also exist; irradiated material may be removed from one experiment and transferred to another in the hot cell for further irradiation.

The fuel rods in the MOX program will employ nondestructive examination as well as many of the destructive techniques. Normal practice is rather broad, and the actual techniques and items of interest will be determined before PIE and will depend on the program's knowledge and confidence level at the time.

\subsection{ANL-W}

The Hot Fuel Examination Facility (HFEF) is a hot-cell complex for the preparation and examination of irradiated experiments and the characterization and testing of waste forms from conditioning of spent fuel and waste. The HFEF is located on the ANL-W site, which is located in the south-west corner of INEEL. The HFEF facility is located on the north end of a double-fenced compound on the ANL-W site.

HFEF consists of two adjacent shielded hot cells (the main and decon cells), a shielded metallographic loading box, an unshielded Hot Repair Area (HRA) and a Waste Characterization Area (WCA). The building is a three-story structure with a basement support area. The building dimensions are $112 \mathrm{ft}$ wide by $154 \mathrm{ft}$ long with a gross floor area of $56,570 \mathrm{ft}^{2}$ and a gross volume of $1,337,200 \mathrm{ft}^{3}$.

The metallographic loading box is located outside the main cell in the metallograph room. This room is located on the north side of the building on the main floor and is separated from the main cell by an operating corridor.

The HRA and WCA are located in the high bay area. The area provides access to the ceiling penetrations in the main and decon cells as well as the HRA roof hatch. The high bay is also used as a staging area for the WCA.

Since the shutdown and defueling of the EBR-II reactor, HFEF has been used for many diverse programs. The primary program, since October 1994, has been the support of the EBR-II defueling and decommissioning. HFEF was responsible for receiving all of the fuel and blanket material from EBR-II and preparing the material for storage in the Radioactive Scrap and Waste Facility (RSWF).

In addition to the handling of the EBR-II fuel, HFEF is the examination facility for both the metal and ceramic waste form experiments from FCF. Cladding hulls from the conditioning of fuel in FCF need to be processed for disposal in a repository. The processing of the cladding hulls and the characterization of the waste form is being tested in HFEF. In addition, equipment is being installed and processes tested for the disposal of the plutonium and fission product waste from the conditioning of EBR-II fuel. The testing and characterization of the ceramic waste forms will be performed in HFEF.

HFEF is presently starting facility modification to accept commercial-sized fuel assemblies from the Watts Bar reactor. These assemblies (specifically, tritium production burnable absorber rods) are the initial assemblies being irradiated as part of DOE's commercial LWR tritium production evaluation. All of the examination equipment in the cell and the cask handling systems are being modified to handle commercialsized casks and fuel rods for examination. These modifications will be complete in mid-1999.

Some of the stainless steel reflector subassemblies used in EBR-II have experienced neutron exposure since the reactor was started in the early $1960 \mathrm{~s}$. The neutron damage to these steels is of interest to the commercial power industry, especially in Japan. Two programs are in place where the stainless steels are being prepared for testing of the neutron damage. These programs involve the cutting and preparation of samples for testing at other laboratories.

The north neutron radiography station has been modified to house a neutron generator for neutron assay of waste. Testing is presently being done on developing neutron assay techniques for the waste from the FCF.

In support of the National Spent Fuel Program, HFEF is presently engaged in the examination of degraded EBR-II fuels that have been stored in water pools at the ICPP. The fuel was shipped to ICPP in sealed containers. During the 15 to 20 years of storage in the water basin at ICPP, some of the containers 
have leaked, causing the fuel to breach. The characterization and examination of the degraded fuel at the HFEF will determine the chemical condition of the fuel as well as the mechanism for breaching. This program will be ongoing during the next 2 years.

\subsubsection{Main Cell}

The HFEF main cell is $70 \mathrm{ft}$ long by $30 \mathrm{ft}$ wide by $25 \mathrm{ft}$ high and has an argon gas atmosphere. The argon gas in the cell is maintained as pure as possible; however, a small amount of moisture is needed to help lubricate and cool the brushes on the electric motors used in cell. Because of this, the moisture and oxygen levels are maintained about $40 \mathrm{ppm}$. The maximum oxygen and moisture levels are kept below 100 $\mathrm{ppm}$. The cell atmosphere is maintained at these levels using a purification system.

An 8- $\mathrm{ft}$ deep space that is located beneath removable flooring and covers the entire width of the cell is used for storage of fuel elements during their examination. Also located in this space are the bases of the examination stages, ducts and filters for the main cell cooling system, and pits for the storage of radioactive materials. A total of ten $1-\mathrm{ft}$ diam by 10-ft long storage pipes are located in the center aisle of the cell for storage of Experimental Breeder Reactor-II (EBR-II) subassemblies. These pits are equipped with forced argon cooling for decay heat removal of their contents.

In addition to the subfloor space, two 3-ft diam pits extend $30 \mathrm{ft}$ below the level of the removable floor at workstations $8 \mathrm{M}$ and $9 \mathrm{M}$ (south-east corner of the cell). These pits are used for storing and handling of long items such as long test loops. Each pit has a corresponding roof penetration so long items can be transferred into the cell and placed in a pit.

The main cell is serviced by two electro-mechanical manipulators (EMMs) rated for $750 \mathrm{lb}$ and two 5-ton bridge cranes. The maximum lift for an EMM in the main cell is $11 \mathrm{ft} 8 \mathrm{in}$. The maximum lift for a crane in the cell is $19 \mathrm{ft} 11-5 / 8$ in.

There are 15 workstations in the main cell. Each workstation is equipped with two master/slave (MS) manipulators. Most of the MS manipulators are Central Research Laboratory (CRL) Model J's rated for a 20-lb vertical lift. Five of the workstations are equipped with CRL System 50 manipulators rated for a 50-lb vertical lift.

\subsubsection{Decon Cell}

The air-filled decon cell is located adjacent to the west end of the main cell and is $30 \mathrm{ft}$ wide by $20 \mathrm{ft}$ long by $25 \mathrm{ft}$ high. There is no subfloor space in the decon cell; however, three 15.5-in. diam by 10-ft deep pits are located at workstation 3D. Another similar pit is located at workstation $4 \mathrm{D}$, and a $3-\mathrm{ft}$ diam by $30-\mathrm{ft}$ deep pit is located at workstation 5D.

The decon cell is equipped with an 8 -ft wide by 7 -ft deep by $11-\mathrm{ft}$ high spray chamber for decontaminating equipment and nonfissile material using a manipulator-held wand. The wand can be used for spraying either water or steam. A chemical addition tank is connected to the water feed line for the addition of decontamination solutions to the water stream. Items being decontaminated are positioned on a 5-ton turntable inside the chamber so that they can be rotated. Both the roof and back side of the spray chamber can be opened remotely so items being decontaminated can be placed inside the chamber.

Material handling inside the decon cell is performed with one 750-1b EMM and one 5-ton crane. The maximum lifting height of the EMM is $11 \mathrm{ft} 8 \mathrm{in}$. and that of the crane is $19 \mathrm{ft} 11 \mathrm{in}$. In addition to the EMM and crane, the cell is equipped with six sets of MS manipulators. Most of the workstations are equipped with one CRL model E MS, rated for a 20 -lb vertical lift, and one CRL model F MS, rated for a 100 -lb vertical lift.

Two pneumatic transfer stations are inside the decon cell. One station originates at station $4 \mathrm{D}$ and runs to the Fuel Conditioning Facility (FCF). The other station originates inside the spray chamber and runs to the radiation safety office (HP office). The pneumatic transfer station that runs to FCF is used for sending small irradiated samples to FCF then on to the Analytical Laboratory (AL) for analysis. 


\subsubsection{Metallographic Loading Box}

The metallographic loading cell is a shielded, gas-tight cell with inside dimensions of $8 \mathrm{ft}$ wide by $6 \mathrm{ft}$ deep by $5 \mathrm{ft}$ high. The cell is provided to accommodate a Leitz metallograph and a scanning electron microscope (SEM) for performing detailed examination of metallurgical samples. The shielding walls (except the front wall) are constructed of 8-in.-thick lead brick. The front wall is 15 -in. thick and is constructed of three 5-in.-thick steel plates. The front wall has a lead-glass window for viewing and two CRL Model L MS manipulators.

\subsubsection{HRA}

The HRA is a series of rooms located directly above the decon cell and west end of the main cell in the high bay area. The outside dimensions of the HRA are $45 \mathrm{ft}$ by $70 \mathrm{ft}$. The primary purpose of the HRA is to perform contact maintenance on cell equipment. The HRA is divided into 12 areas:

1. Hot Repair Room (HRR)

2. Suspect Repair Room

3. Equipment Access Room (Cart Room)

4. Isolation Area Room

5. Survey Room

6. Health Physics (HP) Office

7. Unsealed Slave Repair Room

8. Bagout Room

9. Sealed Slave Arm Repair Glove Box Room

10. Stepout Area Room

11. Glovewall Room

12. Ancillary Area Room

Most of the rooms in the HRA are specific-purpose rooms used for the repair of MS manipulators and other facility-specific equipment. The HRR can be used for the transfer of equipment and materials between the decon cell and HRA. Both the HRR and Suspect Repair Room are serviced by a 5-ton bridge crane. The crane uses a removable rotating hook for remote positioning of the hook. With the rotating hook removed, the maximum lift inside the repair rooms is $13 \mathrm{ft} 6 \mathrm{in}$. With the hook in place the maximum lift inside the HRR is $12 \mathrm{ft} 1 \mathrm{in}$. The drum on the crane is provided with enough cable for a $50-\mathrm{ft}$ lift so that it can be used for raising and lowering equipment into the decon cell.

A $10 \mathrm{ft}^{2}$ roof hatch is located in the ceiling of the HRR, directly above the decon cell roof hatch. The hatch is provided with a 114-in. diam bagging ring so it can be used for the transfer of equipment and material directly from the high bay area into the decon cell.

The equipment access room (cart room) is designed to be a lock in the transfer path between the high bay area and the HRR. The room is $8 \mathrm{ft}^{2}$ by $20 \mathrm{ft}$ high and has a $6 \mathrm{ft} 4$ in. $^{2}$ hatch in the ceiling. The room is generally maintained clean so equipment and materials can be transferred from the high bay area to the room through the hatch. A 5-ton equipment cart runs between the cart room and the HRR for moving the equipment and materials between the two rooms.

\subsubsection{WCA}

The WCA is used for the characterization and sampling of contact-handled transuranic waste (CH TRU) for the Waste Isolation Pilot Plant (WIPP) performance assessment. The facility consists of the Preparation Room, Transfer Room, Waste Characterization Chamber (WCC), Sludge Preparation glove box, Operations Room and the Equipment Room.

The Preparation Room (PR) is used as a staging area for waste going into and out of the WCC. Waste drums awaiting characterization in the WCC are stored in the PR, and waste that has been characterized and is awaiting shipment back to the Radioactive Waste Management Complex (RWMC) is also stored in the room. Personnel access to the PR is through a vestibule on the south-east corner of the room. Waste 
drums and equipment are brought into the room using the high bay crane through a $10-\mathrm{ft}$ high by 8 - $\mathrm{ft}$ wide equipment door on the south wall. High bay crane hook access to the room is through a $2-\mathrm{ft}$ wide by 17-ft-long rollup door on the vertical wall and ceiling above the equipment door. Waste drums and equipment are handled inside the PR by a cantilever-style jib crane rated for a $6000 \mathrm{lb}$ SWL. The crane has a lift height of $12 \mathrm{ft} 8 \mathrm{in}$.

The Transfer Room (TR) is where the waste drums are mated with the WCC. Access to the room is through double doors from the PR. The drums are moved into and out of the TR using a drum cart rated at $2,000 \mathrm{lb} \mathrm{SWL}$. In addition to moving the drums into and out of the room, the cart is used to raise and lower the drums to the drum ports on the bottom of the WCC. Once the drums are bagged to the WCC, they are held in position in the drum ports by turnbuckles which fasten between the bottom of the WCC and an adapter plate under the drums.

The WCC is a $16-\mathrm{ft}$ long by $8-\mathrm{ft}$ high by 8 - $\mathrm{ft}$ deep glove box used for characterization of $\mathrm{CH}$ TRU wastes. The WCC is equipped with shielded viewing windows for personnel protection from low-level gamma and beta radiation. Each window is a three-piece assembly consisting of an inner safety glass, a lexan plate, and leaded glass on the exterior. There are two 200-1b dual Titan 7F manipulators and a 1,500-lb articulated jib crane for handling the waste and equipment inside the glove box. A core boring machine is mounted to the top of the glove box over the west drum port and is used for taking samples from sludge drums. There are 28 glove ports on the WCC. These glove ports are located at various heights for waste handling and equipment repair. A transfer port is located on the east end of the WCC for transferring sludge samples to the Sample Preparation glove box.

The Equipment Room (ER) is located above the WCC and houses the filters, piping, and blowers for the WCC ventilation system. In addition to the ventilation equipment, the ER has a repair glove box for repair of the equipment inside the WCC. The glove box is connected to the west end of the WCC through a transfer tunnel. Equipment is raised and lowered from the repair glove box by a hoist inside the glove box.

The Operations Room (OR) is the area around the WCC and Sample Preparation and Transfer glove boxes. The room provides a mezzanine on the west end of the WCC for the Waste Data Acquisition System (WDAS). The WDAS is used for video taping and audio dubbing of the waste handling operations. A computer controlled switcher is used for switching video sources and recorders. The computer control system for the gas sampling system is mounted on the south end of the WDAS.

In addition to the WDAS, the OR provides monitoring and alarm panels for monitoring the status of the WCA. The panel provides flow and pressure information on the WCC, radiation alarms, breathing air alarms, and fire alarms for the inside of the WCC.

The sludge preparation (SP) glove box is used for preparing sludge samples for shipment to the Idaho Chemical Processing Plant (ICPP) to be analyzed for halogenated VOCs, nonhalogenated VOCs, RCRA heavy metals, and radioassay. After the sludge has been cored, the core section is transferred to the SP glove box where the samples are taken at various locations along the core section. As each sample is taken, it is weighed, placed in a labeled vial, and shipped to ICPP in a Type A container. Some experimentation is being done on real time analysis of the samples using $\mathrm{X}$-ray florescence. The testing of the equipment has not been completed.

\subsection{ORNL}

The Irradiated Fuels Examination Laboratory (IFEL), Building 3525, has a long history of fuel research and examination. It is part of ORNL and is located in Bethel Valley and Melton Valley, approximately 8 miles southwest of the city of Oak Ridge, Tennessee. For three decades this facility has handled a wide variety of fuels including aluminum clad research reactor fuel, both stainless- and zircaloyclad LWR fuel, coated-particle gas cooled reactor fuel, and numerous one of a kind fuel test specimens. In addition, the facility has also done iridium isotope processing and irradiated capsule disassembly.

The IFEL contains a large horseshoe-shaped array of hot cells which are divided into three work areas (Fig. 15). The hot cells are constructed of 3-ft-thick concrete walls with oil-filled, lead-glass viewing windows. The inside of surfaces of the cell bank are lined with stainless steel to provide containment of particulate matter and to facilitate decontamination. Special penetrations are provided for the sealed entry of services such as instrument lines, lights, and electrical power. A pair of manipulators are located at each 


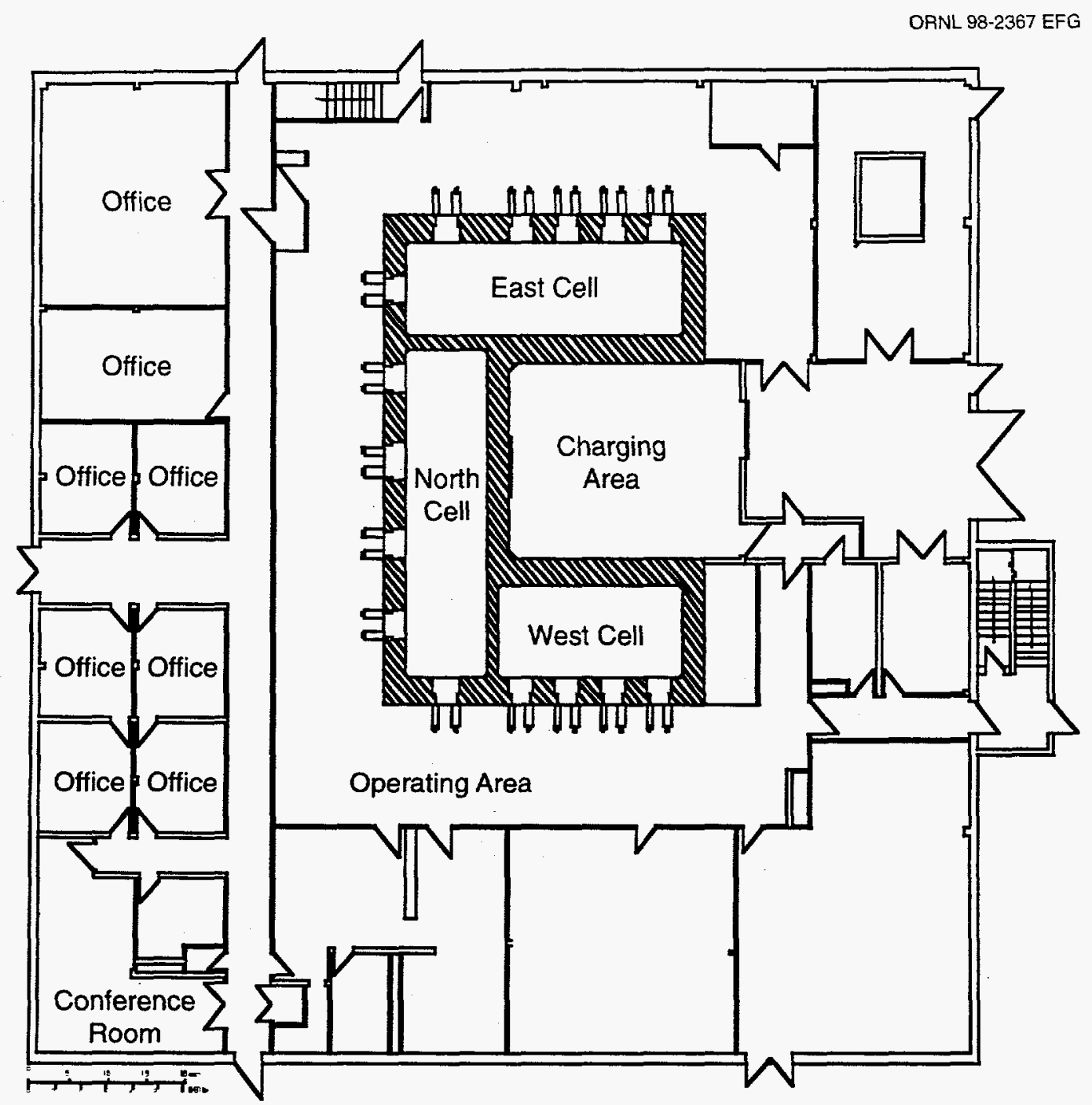

Fig. 15. Building 3525 layout.

of 15 window stations for remote cell operations, and periscopes allow for magnified views of in-cell objects. Heavy objects within each cell bank can be moved by electromechanical manipulators or a 3-ton crane. Fuel materials enter and leave the cells through three shielded transfer stations provided at the rear face of the North cell. Two small diameter (6.5 and 14.5 in.) horizontal transfer stations are used for small objects (less than $8 \mathrm{ft}$ in length). Items up to $4 \times 4 \times 6 \mathrm{ft}$ in size can be transferred through the shielded airlock door system.

The remainder of the laboratory outside the hot cell complex is subdivided into: (1) the charging area; (2) the equipment maintenance air lock areas; (3) the operating area; (4) the truck unloading area, the change room, and a work room; and (5) the rooms housing supporting mechanical equipment. Located on the east side of the truck unloading area is a small laboratory which houses the Core Conduction Cooldown Test Facility (CCCTF). The CCCTF is used to test radioactive samples under controlled thermal conditions while monitoring the samples to determine the release rate of radioactive materials.

A decontamination cell and storage cell, located on the second floor of the building, are connected via hatches to the cells below. A maintenance area incorporating glove box facilities for servicing equipment items adjoins the decontamination cell. Sliding doors separate the decontamination cell, storage cell, and glove maintenance room; a remote crane system provides for retrieval of equipment into and transfer of 
items between these second-floor facilities. Equipment may be transferred between cells through the second-floor pathway. An upper level of the second floor houses ventilation system ducts, control valves, high efficiency particulate air filters, heat exchangers, and air inlets for the equipment storage area, the decontamination area, and the glove maintenance area.

Gases and particulates exhausted from the cell complex are completely contained and shielded until subjected to sufficient filtration to ensure safe stack disposal. The cell air is maintained at negative pressure with respect to the operating areas to ensure confinement. Liquid effluent from the hot cells is handled in a batch mode for disposal to the ORNL low-level liquid waste system.

A variety of shears, machine tools, and cutoff saws are available within the cell for the gross handling and preparation of fuel specimens. The facility has experience in the handling and cutting of a wide variety of capsule and clad materials such as Inconel, stainless steel, zircaloy, aluminum matrix, and graphite-based materials. A gamma scanner is available for the nondestructive examination of moderate-length fuel rods and individual specimens. Metrology equipment such as mass scales and dimensional tools are routinely used and available.

Metallographic equipment including small cutoff saws, polishers, and a shielded metallograph are available for the preparation, handling, and examination of both fuel specimens and clad material. The facility has prepared samples of oxide fuels, carbide fuels, and metal matrix fuels.

Building 3525 also has other facilities outside the main bank of cells: a scanning electron microscope that can handle radioactive specimens, additional gamma analysis and dosimetry equipment for both centimeter-sized and submillimeter-sized samples, and a small stand-alone hot cell with specialized equipment for the handling and analysis of coated-particle fuels.

Radiochemical specimens can be prepared within the facility and delivered to other ORNL laboratories for detailed analysis. ORNL also has extensive computational abilities that can be used to process the hot cell data for comparison with fuel performance models.

PIE capabilities of the IFEL have provided general support to fuels program, fuel characterization, and analysis of candidate irradiated fuel. Typically, the fuel is received at the IFEL, dimensionally inspected, visually examined for defects, and gamma scanned for internal fuel gaps or cracks along with gross fission product migration. The fuel can then be removed from its casing or clad and fuel and clad specimens prepared for metallographic examination, gamma counting, and radiochemical analysis. Actinide and fission product inventories can be determined along with burnup and radial isotope distributions within the fuel. The mechanical properties of the specimens can also be investigated to determine the state of the fuel and/or clad materials. All work is typically done with proper procedures and documentation after concurrence is obtained from the program participants.

Recent work includes extensive support for the Gas Turbine Modular High-Temperature Gas-Cooled Reactor (GT-MHR) program, the New Production Reactor (NPR), a cooperative gas-cooled reactor agreement with Japan, and handling of legacy fuel under the National Spent Fuel program. Personnel are available with experience in a wide variety of fuel PIE programs and analysis techniques along with the detailed reporting and quality control requirements for nuclear programs. The Metals and Ceramics (M\&C) division contains a wealth of experience in fuel fabrication, metal and ceramic material behavior, irradiated material behavior, and material testing. Ongoing programs at ORNL maintain experience in hot cell techniques and analysis. In addition, academic and industrial consultants are available to meet special program needs and to conduct reviews. 


\section{REFERENCES}

1. Los Alamos National Laboratory, Response to the Surplus Plutonium Disposition Environmental Impact Statement Data Call for a Mixed Oxide Fuel Fabrication Facility Located at Pantex Plant, LA-UR97-2067, Rev. 3, June 22, 1998.

2. V. S. White, Initial Data Report and Response to the Surplus Plutonium Disposition Environmental Impact Statement Data Call for the UO ${ }_{2}$ Supply, ORNL/TM-13466, Lockheed Martin Energy Research Corporation, Oak Ridge National Laboratory, November 1997.

3. Shearon Harris Nuclear Power Plant Technical Specifications, Sect. 3.8.

4. U.S. Department of Energy, Storage and Disposition of Weapons-Usable Fissile Materials Final Programmatic Environmental Impact Statement, Vol. 1, Chap. 3, DOE/EIS-0229, December 1996.

5. U.S. Department of Energy, Airborne Release Fractions/Rates and Respirable Fractions for Nonreactor Nuclear Facilities, DOE-HDBK-3010-94, Vols. I and II, December 1994. 1986.

6. Browne and Firestone, Table of Radioactive Isotopes, V. S. Shirley, ed., John Wiley and Sons,

7. U.S. Department of Energy, Criteria for Preparing and Packaging Plutonium Metals and Oxides for Long-Term Storage, DOE-STD-3013-96, September 1996.

8. DOE Order 420.1 , Sect. 4.3 , Nuclear Criticality Safety.

9. 40 CFR 302.4, Table 302.4, List of Hazardous Substances and Reportable Quantities.

10. W. R. Stratton, A Review of Criticality Accidents, DOE/NCT-04, March 1989. 


\section{Page Intentionally Blank}


Appendix A-LA FUEL BUNDLE FABRICATION

A-1 


\section{Page Intentionally Blank}


$\mathrm{PuO}_{2}$

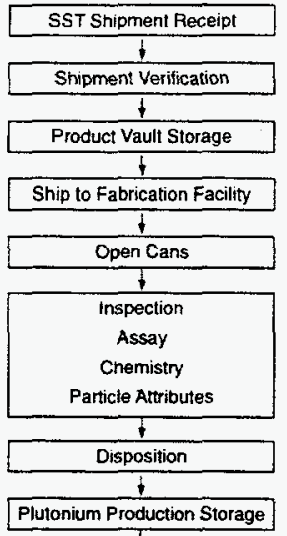

Depleted $\mathrm{UO}_{2}$

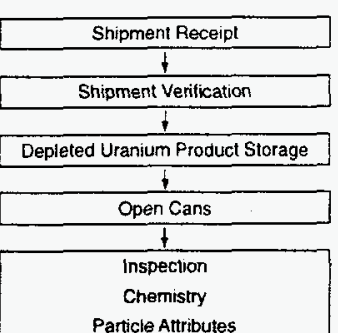

Particle Attributes

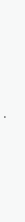

Prepare Master Mix (30\% Plutonium) Powder

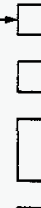

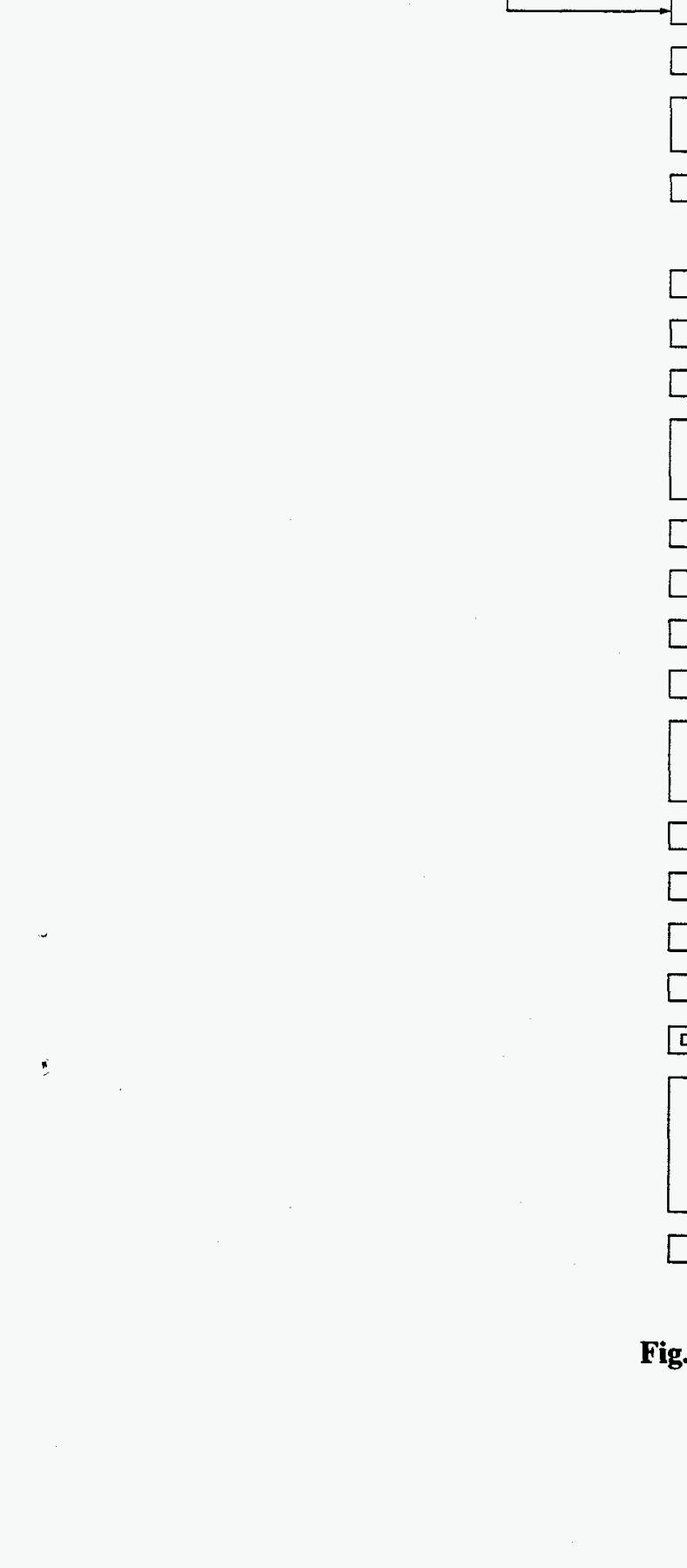

Hard Scrap Recycle (Depleted Uranium/Plutonium)

(Depleted Uraniumplumin)

Fro To\% Ot Batch Makeup)

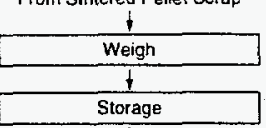

t

Crush (Jaw Crusher)

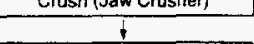

Grind (Ball Mill)

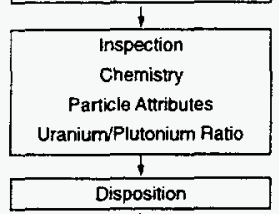

Disposition

Recycle Production Storage

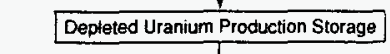

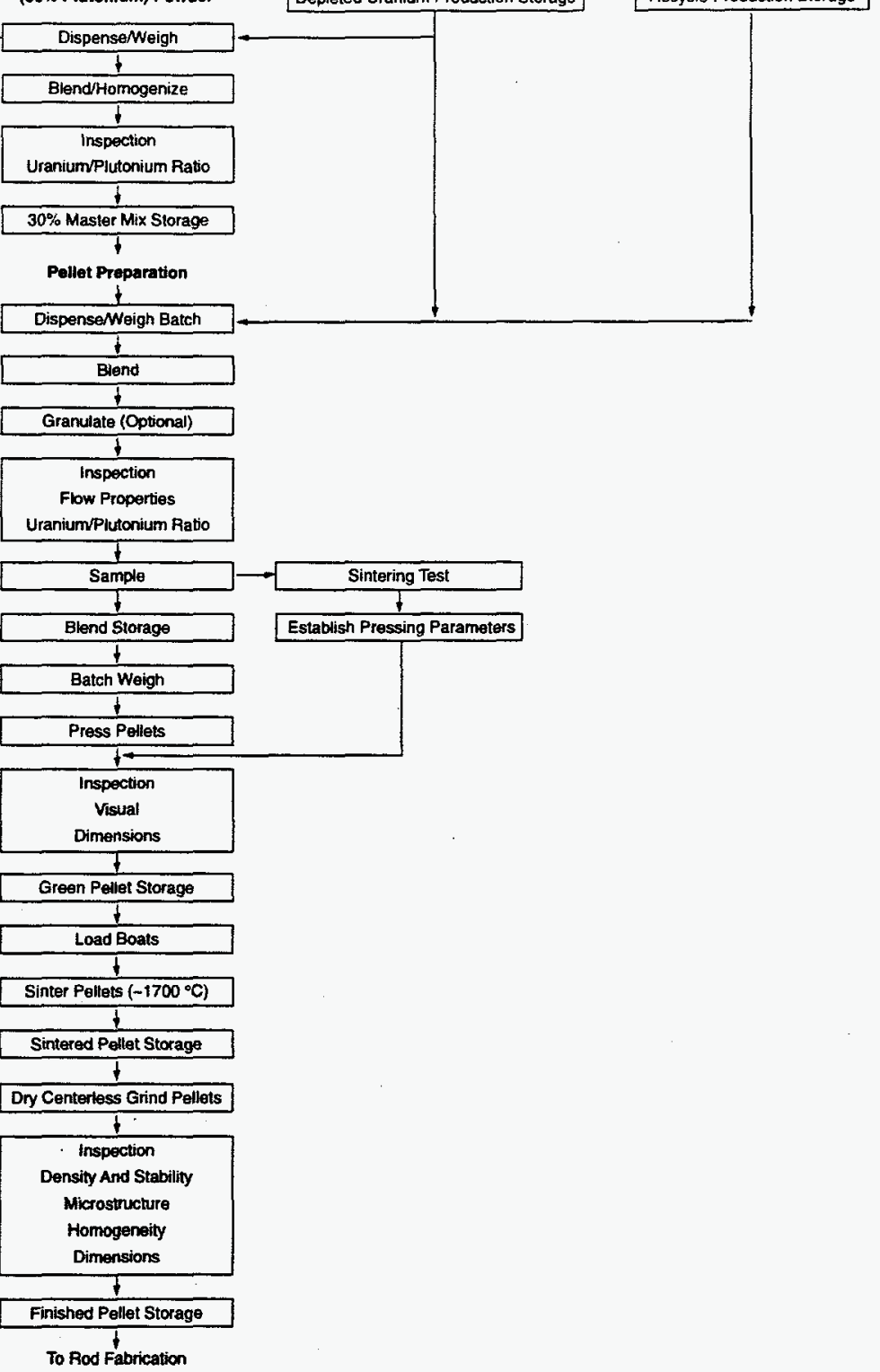

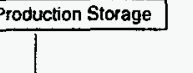

Fig. A.1. LA MOX fuel pellet flow sheet outline. 


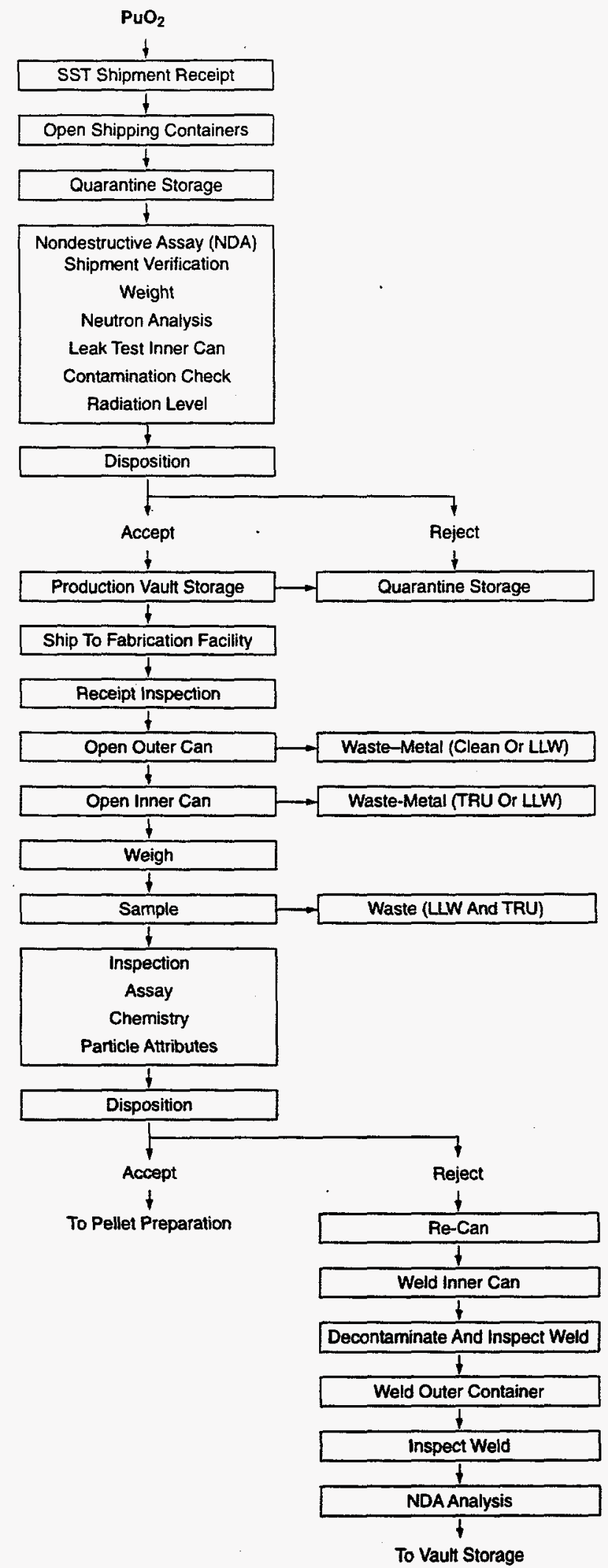

Fig. A.2. LA MOX fuel $\mathrm{PuO}_{2}$ powder receipt and storage. 

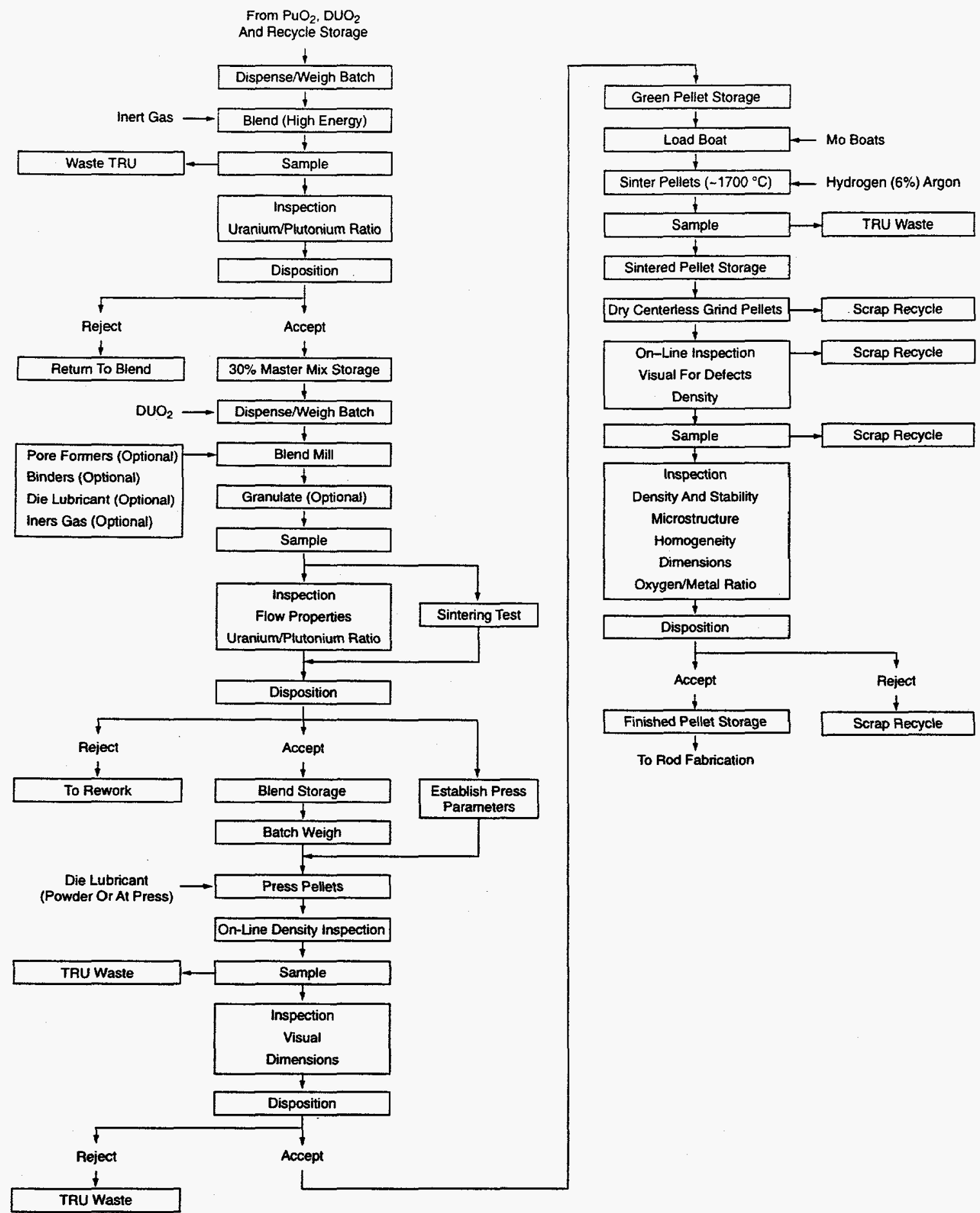

To Rod Fabrication

Fig. A.3. Detailed flow sheet of LA pellet fabrication. 


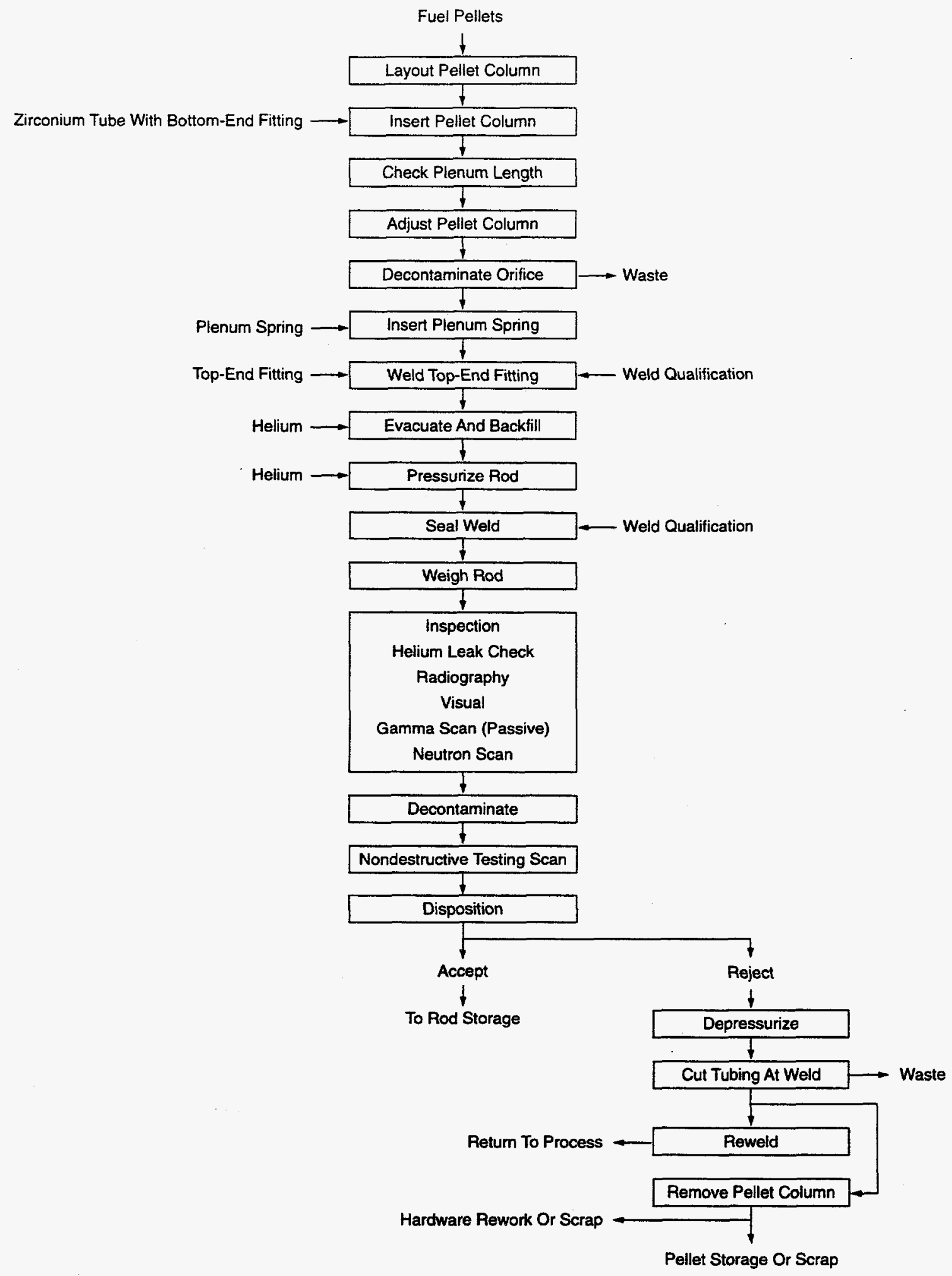

Fig. A.4. Detailed flow sheet of LA rod fabrication. 


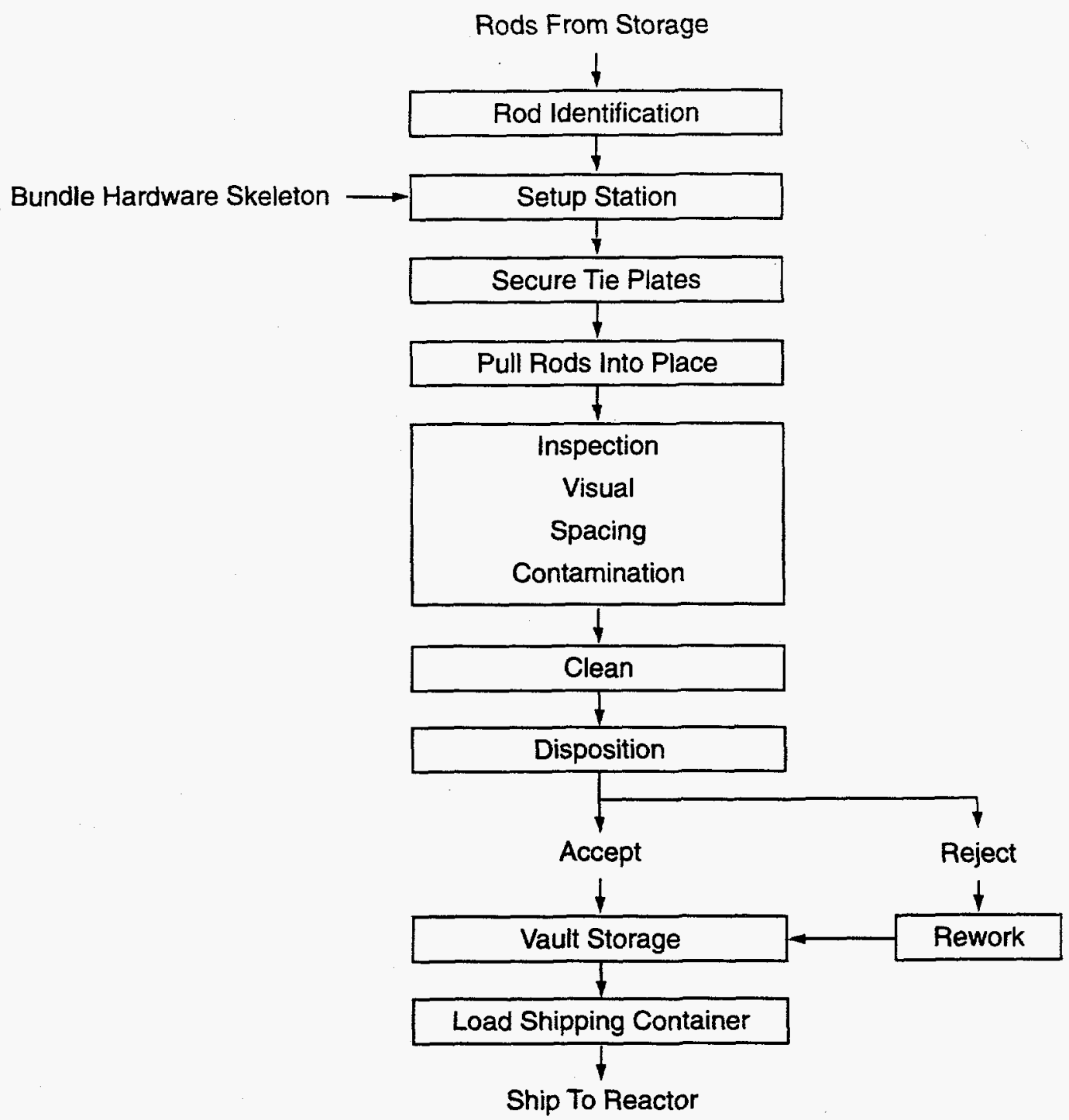

Fig. A.5. Detailed flow sheet of LA bundle assembly (LWR). 
Page Intentionally Blank

A-8 
Appendix B-LA EIS DATA REPORT ASSUMPTIONS

B-1 
Page Intentionally Blank

B-2 
Table B.1. Assumptions used for the LA EIS data reports

1. Material and process requirements are based on producing PWR fuel.

2. $\mathrm{PuO}_{2}$ powder will meet the ASTM C 757-90 specification as received.

3. Depleted $\mathrm{UO}_{2}$ powder will meet the ASTM specification as received.

4. Depleted $\mathrm{UO}_{2}$ (no $\mathrm{PuO}_{2}$ ) will be used to perform all system shakedown tests before introducing plutonium.

5. Table 3 is in terms of $\mathrm{HM}$. The factor for converting $\mathrm{PuO}_{2}$ and depleted $\mathrm{UO}_{2}$ to $\mathrm{HM}$ is $88 \%$.

6. All waste plutonium will be canned and sent to the Immobilization Program for final disposition.

7. All plutonium scrap will be recycled using a dry process.

8. All liquid wastes generated are ancillary to the base process (i.e., laundry, mop water, etc.)

9. Sintering furnaces will stay at temperature during the entire 3-year mission and 1-year startup.

10. Sintering furnaces will be purged with a mixture of argon and $6 \%$ hydrogen at a rate of $10 \mathrm{~L} / \mathrm{min}$.

11. Powder glove boxes will be purged with nitrogen to reduce the potential for oxidizing $\mathrm{UO}_{2}$.

12. All calculated numbers have a precision of no more than two significant figures.

13. The facility will be built on an existing DOE site with a minimum of $4500 \mathrm{ft}^{2}$ available space $\left(3000 \mathrm{ft}^{2}\right.$ for MOX rod processing, $1000 \mathrm{ft}^{2}$ for bundling activities, and $500 \mathrm{ft}^{2}$ for fuel bundle storage).

14. The site will have an existing infrastructure in place to accept the LA mission.

15. Personnel will be required to support a process capacity of $\sim 2$ MT HM per year.

16. Personnel involved in SNM operations must work in pairs and follow specific safety precautions detailed by the site.

17. Personnel must attend required site training. A staffing requirement for training purposes has been included in this estimate.

18. Space will be allocated for safe secure transports (SSTs) carrying plutonium and transportation for uranium so that loading can be accomplished on a follow-up operating shift if the transport arrives near or following the close of standard business.

19. As with the MOX fuel fabrication facility estimate, the staffing requirements assume that $-20 \%$ of the employee's time will be taken through training, vacation, personal leave, or illness. Even though employees cannot necessarily transition from one position to another, a contingency was added to account for nonproductive time.

20. Homogenization of the $\mathrm{PuO}_{2}$ powder will be done at the LA fuel fabrication facility, as will gallium removal operations 
B-4 


\section{LLNL \\ MOX Fuel Lead Assemblies \\ EIS Supplemental Data Call Responses}

May 1998 


\section{LLNL MOX FUEL LA SUPPLEMENTAL DATA CALL RESPONSES}

The Lawrence Livermore National Laboratory (LLNL) is located approximately $65 \mathrm{~km}(40 \mathrm{mi})$ east of San Francisco at the southeastern end of the Livermore Valley in southern Alameda County (Figure 1). Its facilities are located on about 332 ha (821 acres) in Livermore, California. A 2,800-ha (7,000-acre) auxiliary testing range known as Site 300 is located about $29 \mathrm{~km}(18 \mathrm{mi})$ east of the Livermore Site (DOE, 1992a). The proposed MOX Fuel Lead Assembly program would be conducted at the LLNL Livermore Site; therefore, this document will contain no further discussion of Site 300 . This data is being provided in response to a memo titled "Supplement to the Lead Assemblies (LAs) Data Call" dated July 29, 1997.

\subsection{General Site Data Needs}

\subsection{General Description of Activities Occurring at LLNL}

LLNL is a multidisciplinary research facility engaged in a variety of programs for DOE and other Government agencies. Its primary mission is to ensure that the nation's nuclear weapons remain safe, secure, and reliable and to prevent the spread and use of nuclear weapons worldwide. It conducts research and development activities in the basic sciences, mathematics, and computing, with applications to these mission areas and to a broad range of programs including nonnuclear defense; nuclear and nonnuclear energy; atmospheric, space, and geosciences; bioscience and biotechnology; and the environment.

The Plutonium Facility, Building 332 (B332), was constructed circa 1960 and has been enlarged and modified since. Major activities conducted at the Plutonium Facility support the mission of the DOE Stockpile Technology Development, Materials..Disposition, and Environmental Management Programs. Processes for advanced weapons manufacturing, safe disposition of surplus plutonium, and stabilization of excess plutonium for long term storage are being developed. The LLNL Plutonium Facility is equipped with research and development laboratories where plutonium, uranium, and other radioactive or nonradioactive materials can be safely handled. Vaults within the Facility provide safe storage for current and future development needs. The Facility is fully equipped with analytical and metallography laboratories.

Building 334 , adjacent to Building 332 , is a three floor facility that is comprised of the Engineering Test Bay (ETB) and the Radiation Measurements Facility (RFM). The ETB is used to conduct thermal and dynamic tests on weapon components; the RMF, located in the Intrinsic Radiation (INRAD) Bay, is used to make intrinsic radiation measurement $f$ of various components. The INRAD and ETB byas provide primary and secondary confinement barriers against the release of radioactive materials. Building 334 also contains analytical, metallography, scrap recovery, and other equipment.

Building 335, also adjacent to Building 332, contains a high bay with approximately 25 feet of vertical clearance and a bridge crane traversing the full length of the high bay. This high bay is currently used for equipment assembly, training, and technician work space. The facility also houses an alternate portal area for accessing the radioactive materials area (RMA) of Building 332. This portal area consists of a lobby, change rooms, bathroom facilities with showers, security booths and portal safeguard monitors. The remainder of the facility is currently used for equipment and records storage, as well as office space. 


\subsection{History and Previous Uses of the Site}

Before World War II, the present-day LLNL Livermore Site was part of the Wagoner Ranch and cattle grazing was the dominant land use. The Navy purchased the site in 1942, and established the Livermore Naval Air Station as a flight-training base. Runways were constructed near the center of the site with a rectangular grid street system along the southern portion of the site (UC, 1986).

The transition from Navy operations to a research facility began in 1950 when the California Research and Development Corporation (a subsidiary of Standard Oil, Inc) began construction of the Materials Test Accelerator facility as authorized by the Atomic Energy Commission. In 1951, the University of California Radiation Laboratory in Berkeley began using some of the Livermore facilities in support of nuclear weapons research being conducted by the Los Alamos Scientific Laboratory in New Mexico (UC, 1986). LLNL was established as a nuclear weapons design laboratory in 1952.

\subsection{Site Annual Environmental Report}

The 1996 Site Annual Environmental Report is included as Attachment 1 and is available at http://www.llnl.gov/saer/. The LLNL Comprehensive Site Plan 1997 is available online at http://www.llnl.gov/comp_plan.

\subsection{Current Employment Levels}

Current employment levels at LLNL are 7,665 employees (Employee Residence Analysis, January 22, 1998).

\subsection{Site Worker Radiological Exposure Data}

Data on radiological exposure for the LLNL Livermore Site for the last three years for which complete data are available is summarized in Table 1. The average dose for the LLNL Site is for all employees, data from B332 is for workers receiving a dose greater than 50 mrem.

Table 1. LLNL Radiological Exposure Data

\begin{tabular}{|c|c|c|c|c|}
\hline \multirow{2}{*}{ Year } & \multicolumn{2}{|c|}{ Annual Average Dose (rem) } & \multicolumn{2}{c|}{ Collective Dose (person-rem) } \\
\cline { 2 - 5 } & LLNL Site & B332 & LLNL Site & B332 \\
\hline 1995 & 0.001 & 0.24 & 13.0 & 8.2 \\
\hline 1996 & 0.002 & 0.26 & 15.1 & 10.8 \\
\hline 1997 & 0.002 & 0.29 & 18.2 & 13.5 \\
\hline
\end{tabular}




\subsection{General Meteorological and Climatological Conditions}

The climate at the LLNL Livermore Site and the surrounding region is classic Mediterranean with warm dry summers and mild rainy winters. The average annual temperature at the Livermore Site in 1996 was $15^{\circ} \mathrm{C}\left(59^{\circ} \mathrm{F}\right)$; seasonal temperatures range between winter nighttime lows of about $-5^{\circ} \mathrm{C}\left(23^{\circ} \mathrm{F}\right)$ and summer daytime highs around $40^{\circ} \mathrm{C}\left(104^{\circ} \mathrm{F}\right)$. Rainfall and winds exhibit strong seasonal patterns. Most precipitation occurs between October and April with little rainfall in the warmer months. The highest and lowest annual precipitation on record are $812 \mathrm{~mm}$ (32 in.) and $122 \mathrm{~mm}$ (5 in.), respectively. The average annual rainfall is $368 \mathrm{~mm}$ (14 in.). In 1996, the Livermore Site received $456 \mathrm{~mm}$ (18 in.) of rain. Prevailing annual winds at the Livermore Site are from the west and southwest; however, in the winter, winds blow from the northeast. These wind patterns tend to be dominated by the thermal draw of the warm San Joaquin Valley that results in wind blowing from the cool ocean toward the warm valley, increasing in intensity as the valley heats up (LLNL, 1997). The Livermore Valley rarely experiences severe weather. Thunderstorms occur on fewer than 10 days per year and are not intense. Hail occurs less frequently than thunderstorms (DOE, 1992a).

\subsection{Compliance Agreements}

The LLNL Site was added to the Environmental Protection Agency's (EPA) National Priorities List (NPL) in July 1987, based on the presence of volatile organic compounds (VOCs) in groundwater. In November 1988, DOE, EPA, the California Department of Health Services, and the Bay Area Regional Water Quality Control Board signed a Federal Facility Agreement to facilitate compliance with the Comprehensive Environmental Response, Compensation, and Liability Act of 1980 (CERCLA), the Superfund Amendments and Reauthorization Act of 1986 (SARA), and applicable State environmental laws.

A Remedial Investigation/Feasibility Study (RI/FS) was prepared pursuant to CERCLA which outlined DOE's cleanup strategy for the LLNL Livermore Site. A Record of Decision was issued on July 15, 1992 (DOE, 1992b) and documented DOE's decision to pump and treat contaminated groundwater throughout the LLNL Livermore Site and construct approximately seven small treatment facilities. The selected remedies address the principal concerns at LLNL by removing the contaminants in groundwater and soil vapor, and treating them at the surface to levels protective of human health and the environment.

To fulfill requirements of the Endangered Species Act, DOE and LLNL received a Biological Opinion from the U.S. Fish and Wildlife Service in October 1997 for potential impacts of LLNL flood control maintenance activities in the Arroyo Las Positas to the Federally-threatened California red-legged frog. Mitigation requirements are designed to minimize direct impacts and to compensate for loss of frog habitat.

\subsection{Environmental Justice}

In accordance with the presidential Executive Order 12898, dated February 11, 1994, DOE has established procedures for identifying and addressing, as appropriate, disproportionately high and adverse human health or environmental effects of its programs, policies, and activities on minority populations and low-income populations, native American tribes, and populations of 
non-English speaking residents (Executive Order 12898, 59 FR. 7629). The following information was adapted from the Final Programmatic Environmental Impact Statement for Stockpile Stewardship and Management (DOE, 1996a).

For this assessment, environmental justice is evaluated for impacts within the LLNL Site region, defined as an $80 \mathrm{~km}(50 \mathrm{mi})$ radius around the LLNL Site, and within the local area. Lazaro et al. (1996) presents the demographic analysis of minority and low-income population distributions on a regional and local basis.

In the LLNL Site region based on the 1990 census, 7 percent of the population was low income and 41 percent was minority. These values are lower percentages of both low-income and minority persons than the California state averages (12 percent low-income and 43 percent minority). However, within that area, census tracts closer to LLNL tend to have a higher proportion of minority population but a lower proportion of low-income population than do census tracts farther from the site.

Thus, the local area impacts from the proposed action could disproportionately affect minorities. However, none of the local area environmental or health impacts from the proposed project would be highly adverse or significant. Therefore, no environmental justice issues for local area impacts have been identified for this site.

For the population in the LLNL Site region within $80 \mathrm{~km}(50 \mathrm{mi})$ of LLNL Site, both minorities and low-income populations are in lower proportion to other populations than in California as a whole. Thus, no environmental justice issues for regional impacts are identified for this site.

\subsection{Location Specific Data}

\subsection{General Facilities Information}

\subsubsection{Existing EAs/EISs Modified for MOX LA}

The August 1992 Final Environmental Impact Statement and Environmental Impact Report for Continued Operation of Lawrence Livermore National Laboratory and Sandia National Laboratories, Livermore(1992 EIS/EIR) (DOE, 1992a), and its January 21, 1993 DOE Record of Decision (58 FR 6268) address activities occurring in Buildings 332, 334, and 335 . A supplement analysis is presently being conducted to evaluate the continued adequacy of the 1992 EIS/EIR.

The 1992 EIS/EIR is available online at http://raleigh.dis.anl.gov:81/fpims_9/eis/eis0157/html/0157toc.htm.

\subsubsection{Current employment levels}

Approximately 100 employees work in B332. B334 is a test facility and up to approximately 4 people may work in the building during testing operations. Approximately 12 employees work in Building 335. 


\subsection{Specific Facilities Information}

\subsubsection{Land Use}

Table 2. Requested Information for Land Use

BUILDING COORDINATES

\begin{tabular}{|c|c|c|c|}
\hline & B332 & B334 & B335 \\
\hline Latitude & $\begin{array}{l}37^{\circ} 41^{\prime} 01.456^{\prime \prime} \\
\text { north latitude }\end{array}$ & $\begin{array}{l}37^{\circ} 41^{\prime} 03.148^{\prime \prime} \\
\text { north latitude }\end{array}$ & $\begin{array}{l}37^{\circ} 41^{\prime} 01.582 " \\
\text { north latitude }\end{array}$ \\
\hline Longitude & $\begin{array}{l}121^{\circ} 42^{\prime} 22.287^{\prime \prime} \\
\text { west longitude }\end{array}$ & $\begin{array}{l}121^{\circ} 42^{\prime} 25.359^{\prime \prime} \\
\text { west longitude }\end{array}$ & $\begin{array}{l}121^{\circ} 42^{\prime} 20.716^{\prime \prime} \\
\text { west longitude }\end{array}$ \\
\hline Elevation: & $619.2 \mathrm{ft}$ & $613.1 \mathrm{ft}$ & $619.2 \mathrm{ft}$ \\
\hline
\end{tabular}

\subsubsection{Air Quality}

Facility operations are assessed for radiological and nonradiological air emissions to evaluate compliance with local, state, and federal regulations and to ensure that human health and the environment are protected. Evaluations are based on data from air surveillance monitoring and effluent emissions monitoring and inventories. The Livermore Site is located within the San Francisco Bay Area Air Quality Management District (BAAQMD) and EPA Region IX. The area is currently designated as non-attainment for ozone with respect to state regulation. By approximately mid-1998, the area also may be designated as non-attainment for ozone under federal standards.

\subsubsection{Description of Typical Releases}

In 1996 , radioactive air emissions were monitored using 103 radioactivity samplers on exhausts at 9 facilities at the Livermore Site. Gross alpha, gross beta, and tritium are monitored. Tritium emissions from the Tritium Facility, Building 331, were $8.0 \times 10^{12} \mathrm{~Bq}$ $(210 \mathrm{Ci})$ for 1996 , and account for the majority of radioactive discharges to the atmosphere from the monitored facilities. Estimates of releases are also calculated for operations having the potential to release radiological materials to the air, but whose discharges are not monitored. A summary of measured and calculated radioactive emissions is presented in Table 5-3 of the 1996 Site Annual Environmental Report (LLNL, 1997). The radioactive emissions for 1996 from all Livermore Site operations resulted in an annual dose of $0.93 \mu \mathrm{Sv}(0.093 \mathrm{mrem})$ to the maximally exposed member of public.

The Livermore Site currently emits approximately $100 \mathrm{~kg} /$ day of criteria air pollutants (nitrogen oxides, sulfur oxides, particulate matter (PM10), carbon monoxide, and lead). The largest sources of criteria pollutants from the Livermore Site are surface coating operations, internal combustion engines, solvent operations, boilers, and various experimental, testing, and process sources.

The estimated releases from exempt and permitted sources of air pollutants at the Livermore Site can be compared to the most recent estimated 1995 daily release of air pollutants for the $5 / 20 / 98$ 
entire Bay Area. For example, the total emissions of oxides of nitrogen released in the Bay Area is approximately $4.8 \times 10^{5} \mathrm{~kg} /$ day compared to an estimate for LLNL releases of 57.7 $\mathrm{kg} /$ day for the Livermore Site $(0.012 \%$ of total Bay Area emissions). The BAAQMD estimate for reactive organic emissions is $5 \times 10^{5} \mathrm{~kg} /$ day, versus Livermore Site's estimated releases of $30.3 \mathrm{~kg} /$ day $(0.006 \%$ of total Bay Area emissions) in 1996.

\subsubsection{Nearest Ambient Air Quality Monitoring Station}

The nearest ambient air monitoring station is located on Old First Street in Livermore; coordinates are:

UTM East: $608.9 \quad$ UTM North: 4171.4

Latitude: $\quad 37.7 \quad$ Longitude: 121.8

\subsubsection{Recent Annual Wind Rose Data}

Wind rose data for 1996 is shown in Table 3.

Table 3. Wind rose data for LLNL's Livermore Site at the $10-\mathrm{m}$ level for 1996 Values are frequency of occurrence (in percent). Columns and rows may not exactly sum to the listed totals due to rounding.

\begin{tabular}{lllllll} 
Wind speed & & & \multicolumn{2}{c}{ Range } & $(\mathbf{m} / \mathbf{s})$ & \\
Direction & $\mathbf{0 . 0 - 0 . 4}$ & $\mathbf{0 . 5 - 2 . 9}$ & $\mathbf{3 . 0 - 4 . 9}$ & $\mathbf{5 . 0 - 6 . 9}$ & $\mathbf{2 7 . 0}$ & Total \\
NNE & 0.84 & 2.34 & 1.420 & .53 & 0.29 & 5.4 \\
NE & 0.84 & 3.41 & 1.52 & 0.10 & 0.00 & 5.9 \\
ENE & 0.84 & 2.22 & 0.13 & 0.00 & 0.00 & 3.2 \\
E & 0.84 & 2.23 & 0.00 & 0.00 & 0.00 & 3.1 \\
ESE & 0.84 & 2.26 & 0.00 & 0.00 & 0.00 & 3.1 \\
SE & 0.84 & 1.82 & 0.00 & 0.00 & 0.00 & 2.7 \\
SSE & 0.84 & 1.76 & 0.07 & 0.00 & 0.00 & 2.7 \\
S & 0.84 & 5.51 & 1.01 & 0.31 & 0.18 & 7.9 \\
SSW & 0.84 & 7.93 & 1.93 & 0.92 & 0.22 & 11.8 \\
SW & 0.84 & 7.95 & 6.21 & 2.56 & 0.35 & 17.9 \\
WSW & 0.84 & 8.32 & 4.88 & 1.19 & 0.08 & 15.3 \\
W & 0.84 & 4.58 & 5.13 & 0.99 & 0.05 & 11.6 \\
WNW & 0.84 & 1.78 & 0.57 & 0.14 & 0.00 & 3.3 \\
NW & 0.84 & 1.40 & 0.07 & 0.00 & 0.00 & 2.3 \\
NNW & 0.84 & 1.05 & 0.11 & 0.02 & 0.00 & 2.0 \\
N & 0.84 & 0.65 & 0.26 & 0.12 & 0.06 & 1.9 \\
Total & $\mathbf{1 3 . 4}$ & $\mathbf{5 5 . 2}$ & $\mathbf{2 3 . 3}$ & $\mathbf{6 . 9}$ & $\mathbf{1 . 2}$ & $\mathbf{1 0 0}$
\end{tabular}

\subsubsection{Hourly Meteorological Data}

Hourly data from 1994 is provided in Attachment 2 on a diskette. 
Table 4. Ambient Air Quality Data

\begin{tabular}{|l|l|}
\hline \multicolumn{1}{|c|}{ Requested Information } & Estimated Releases \\
\hline $\begin{array}{l}\text { Most recent available data for ambient } \\
\text { air quality measured at closest } \\
\text { monitoring station, including: }\end{array}$ & \\
\hline carbon monoxide $(\mathrm{CO})$ & $10.3 \mathrm{~kg} /$ day \\
\hline nitrogen dioxide $\left(\mathrm{NO}_{2}\right)$ & $57.7 \mathrm{~kg} /$ day \\
\hline sulfur dioxide $\left(\mathrm{SO}_{2}\right)$ & $0.81 \mathrm{~kg} /$ day \\
\hline ozone $\left(\mathrm{O}_{3}\right)$ & $\mathrm{N} / \mathrm{A}$ \\
\hline particulate matter $\left(\mathrm{PM}_{10}\right)$ & $5.5 \mathrm{~kg} /$ day \\
\hline total suspended particulate $(\mathrm{TSP})$ & $\mathrm{N} / \mathrm{A}$ \\
\hline organic and volatile organic & $30.3 \mathrm{~kg} / \mathrm{day}$ \\
\hline
\end{tabular}

\subsubsection{Water}

\subsubsection{Surface Water}

The main surface water features at the Livermore Site are the Arroyo Las Positas and Arroyo Seco. Arroyo Las Positas drains in the hills directly east and northeast of the Livermore Site (Figure 2) and usually flows only after storms. This channel enters the Livermore Site from the east, is diverted along a storm ditch around the northern edge of the site, and exits the site at the northwest comer. Arroyo Seco flows through the very southwest corner of the Livermore Site. Arroyo Las Positas flows into Arroyo Seco west of the site. Both stream channels are intermittent with seasonal flows occurring mainly in the winter months. Arroyo Seco and Arroyo Las Positas are mostly intermittent streams, though in wet years Arroyo Las Positas can have flow running through the Livermore Site all year. Both Arroyo Seco and Arroyo Las Positas have permanent pools of water, even in dry years. Arroyo Las Positas and Arroyo Seco combine downstream of the LLNL Livermore Site eventually running into Arroyo Mocho. Arroyo Mocho joins down stream into Arroyo de la Laguna which eventually runs into Alameda Creek. Alameda Creek ultimately discharges into the San Francisco Bay.

A map is included as Figure 2.

\subsubsection{Floodplains}

Two areas on the Livermore Site are within the 100-year floodplains of the Arroyo Las Positas and Arroyo Seco. However, no existing onsite structures are within the 100-year floodplain. Channels routing Arroyo Las Positas and Arroyo Seco through the Livermore Site would contain a 100-year flood.

A map of the 100- and 500-yr floodplains is included as Figure 3. 


\subsubsection{Hydrogeologic Units and Conditions}

Two groundwater systems underlie the LLNL area-a shallow system composed predominately. of heterogeneous alluvial deposits, and a deeper system composed of fluvial and lacustrine sediments. Regional groundwater flow is generally westward, locally stratified, and primarily horizontal, but the flow paths deepen gradually westward toward the center of the basin. The upper and lower systems are separated by a regional confining layer that slopes westward in the upper part of the Lower Member of the Livermore Formation, which varies in depth from about $60 \mathrm{ft}$ in the eastern part of LLNL to about $400 \mathrm{ft}$ near the western LLNL boundary (DOE, 1990).

Depth to groundwater in the LLNL area varies from about $110 \mathrm{ft}$ in the southeast corner of LLNL to $30 \mathrm{ft}$ in the northwest. Groundwater gradients vary from relatively steep $(0.02 \mathrm{ft} / \mathrm{ft})$ in the northeast comer of LLNL to fairly flat $(0.01 \mathrm{ft} / \mathrm{ft})$ toward the west. Some of the groundwater in the LLNL vicinity eventually flows about $1-1 / 2$ mi west-northwest to Arroyo Las Positas near First Street in Livermore, where it discharges, and through a possible "gap" between Mocho I and Mocho II subbasins about 1-1/2 mi west of LLNL, where some of it may continue to flow westward (DOE, 1990).

Pumping tests and the distribution of volatile organic compounds (VOCs) have demonstrated a high degree of horizontal communication in the LLNL subsurface. Calculations of hydraulic conductivity and groundwater gradients, along with history matching of VOC migration, indicate an average groundwater velocity of about $70 \mathrm{ft} / \mathrm{y}$ in permeable sediments. Much less communication is observed in the vertical direction. Although downward vertical hydraulic gradients exist over much of the site, the layered nature of the alluvium prevents significant downward migration of VOCs (DOE, 1990).

\subsubsection{Sole-Source Aquifers}

There are no sole-source aquifers beneath the LLNL Livermore Site.

\subsubsection{Classification of Groundwater}

Groundwater in the vicinity of LLNL is generally suitable for use as domestic, municipal, agricultural, and industrial supply; however, industrial and agricultural uses of some shallower groundwater may be limited by its marginal quality. Furthermore, groundwater less than about $300 \mathrm{ft}$ deep is usually unsuitable for domestic use without treatment (Thorpe et al., 1990).

Volatile organic compounds occur in the groundwater at relatively low concentrations that underlie approximately 85 percent of the Livermore Site. In the 1940's when the U.S. Navy operated the site, a leak of approximately 17,000 gallons of leaded gasoline occurred in the southern portion of the LLNL Livermore Site. Due to the very slow groundwater movement in the area, it is believed that the fuel hydrocarbons have not traveled more than $\mathbf{5 0 0}$ feet from the site of the leak. Various metals (e.g., chromium and lead) occur at various locations throughout the site at concentrations exceeding regulatory driven standards. Finally, tritium levels exceeding regulatory standards occur at a relatively small area in the southeast part of the LLNL Site. 


\subsubsection{Description of Ultimate Source of Water}

Water used at the LLNL Livermore Site is purchased primarily from the City of San Francisco and delivered from the Hetch Hetchy Aqueduct system. LLNL Livermore Site purchases water from the Alameda County Flood and Water Conservation District, Zone 7 as a secondary water supply. Water from the Hetch Hetchy system is received at the Mocho standpipes and delivered to the Sandia Livermore Site and ultimately to the LLNL Livermore Site through pipelines and tanks owned and maintained by LLNL. Water from Zone 7 is delivered to the Livermore Site at a pump station located in the northwestern corner of the site and pumped through LLNL pipes to the delivery tanks located at the Sandia Livermore Site. Water is distributed to the Livermore and Sandia sites from the holding tanks located at Sandia.

\subsubsection{Discharge Points for Wastewater and Permit Limits and Conditions}

Process wastewater is managed following LLNL internal guidelines and if it meets the LLNL internal discharge limits is discharged to the LLNL sanitary sewer system. These limits are designed to ensure that discharges from the LLNL sanitary sewer at Building 196 (the final discharge monitoring location) meet the discharge limits set forth in the City of Livermore's Wastewater Discharge Permit/Chemical Storage Permit (Permit number 1250 (97-98). Discharges also must meet requirements identified in DOE orders 5400.1 and 5400.5 . Wastewater discharges and discharges of storm water associated with industrial activities to waters of the state or navigable waters of the United States are regulated by the San Francisco Bay Regional Water Quality Control Board through Waste Discharge Requirements (Waste Discharge Requirements Order Number 95-174) and National Pollutant Discharge Elimination System permits (NPDES permit number CAS0030023).

No data on flow rates for the two intermittent arroyos are available for portions of the arroyos immediately downstream of LLNL.

\subsubsection{Biological Resources}

\subsubsection{Plant and Animal Species}

The Livermore Site is located near the boundary of the San Joaquin Valley and the San Francisco Bay Area geographic subregions of the California Floristic Province (Hickman, 1993). The site includes developed areas surrounded by security zones of mostly grassland. Developed land area includes approximately 78 percent of the site. The undeveloped land in the security zones is grassland dominated by nonnative grasses such as ripgut brome (Bromus diandrus) and slender oat (Avena barbata) (DOE, 1992a).

Numerous wildlife species have been reported at the Livermore Site and include species that are found in the grassland habitat of the security zones and those that live in the developed areas or along the arroyos. As shown in Attachment 3,49 Federal- and State-listed threatened, endangered, and other special status species potentially occur on and in the vicinity of the Livermore Site. Twelve of these species have been observed on the Livermore Site. The redlegged frog (Federal threatened), Western burrowing owl (State Species of Concern), and the white-tailed kite (State Protected) breed onsite (Figure 4), other species are infrequent visitors. Although suitable habitat for several listed species exists onsite, potential occurrence of most of the species in Attachment 3 is minimal due to the lack of suitable habitat. No critical habitat for 
threatened and endangered species, as defined in the Endangered Species Act (50 CFR 17.11; 50 CFR 17.12), exists on the Livermore Site. A more detailed account of plants, wildlife, and special-status species at LLNL is in the Final Environmental Impact Statement and Environmental Impact Report for Continued Operation of Lawrence Livermore National Laboratory and Sandia National Laboratories, Livermore (DOE, 1992a) and in the Final Programmatic Environmental Impact Statement for Stockpile Stewardship and Management (DOE, 1996a).

\subsubsection{Wetlands and Other Sensitive Habitats}

Approximately 2 acres of jurisdictional wetlands at the Livermore Site have been delineated and are limited to the Arroyo Las Positas channel along the northern boundary of the site (Figure 4). Saltgrass (Distichlis spicata), a species of sedge (Carex spp.) and cattail (Typha spp.) are the dominant plants. Both standing and flowing water have been observed and the soil is sandy.

\subsubsection{Utilities}

Table 5. Utility Usage and Capacity

\begin{tabular}{|l|l|l|l|}
\hline Requested Information & \multicolumn{3}{|c|}{ LLNL } \\
\hline $\begin{array}{l}\text { Utility usage and capacity } \\
\text { information for those utilities present } \\
\text { at the proposed facility location }\end{array}$ & \multicolumn{2}{|c|}{ Current Usage } & Current Capacity \\
\hline & Average & Peak & Peak \\
\hline Water & $874,138,983 \mathrm{l} / \mathrm{yr}$ & $921,868,000 \mathrm{l} / \mathrm{yr}$ & $10,977,6601 /$ day \\
\hline $\begin{array}{l}\text { Sanitary Wastewater, including } \\
\text { Process Wastewater }\end{array}$ & $106,515,453 \mathrm{gal} / \mathrm{yr}$ & $\begin{array}{l}127,303,423 \\
\text { gal/yr }\end{array}$ & $1,100 \mathrm{gal} / \mathrm{min}$ \\
\hline Electricity & $295,919 \mathrm{MWh} / \mathrm{yr}$ & $308,500 \mathrm{MWh} / \mathrm{yr}$ & $100 \mathrm{MVA}$ \\
\hline Natural Gas & $13,017,173 \mathrm{~m}^{3} / \mathrm{yr}$ & $13,767,507 \mathrm{~m} / \mathrm{yr}$ & $4,400 \mathrm{~m} / \mathrm{hr}$ \\
\hline Fuel Oil (gasoline and diesel) & $1,257 \mathrm{~m}^{3} / \mathrm{yr}$ & $1,404 \mathrm{~m}^{3} / \mathrm{yr}$ & $\mathrm{NA}$ \\
\hline Steam, lb/hr & $\mathrm{NA}$ & $\mathrm{NA}$ & $\mathrm{NA}$ \\
\hline
\end{tabular}

a 5-yr average, FY93 - FY97.

b Process wastewater is approximately $14 \%$ of the total. 


\subsubsection{Waste Management}

Table 6. Requested Information for Waste Management

\begin{tabular}{|c|c|c|c|c|c|c|}
\hline \multirow[b]{2}{*}{$\begin{array}{l}\text { Waste } \\
\text { Category }\end{array}$} & \multirow{2}{*}{$\begin{array}{l}\text { Current } \\
\text { Annual } \\
\text { Generation } \\
\text { Rate }^{\text {a }}\end{array}$} & \multirow[b]{2}{*}{$\begin{array}{l}\text { Amount in } \\
\text { Inventory }\end{array}$} & \multicolumn{4}{|c|}{ Available TSD Facilities } \\
\hline & & & $\begin{array}{l}\text { Building } \\
\text { Name or } \\
\text { Number } \\
\end{array}$ & $\begin{array}{l}\text { TSD } \\
\text { Method }^{\mathrm{c}}\end{array}$ & Inventory ${ }^{a}$ & Capacity $^{c}$ \\
\hline $\begin{array}{l}\text { Transuranic } \\
\text { (TRU) } \\
\text { Liquid } \\
\text { Solid }\end{array}$ & $27 \mathrm{ft}^{3}$ & $2,180 \mathrm{ft}^{3}$ & $\begin{array}{l}\text { B233 } \\
\text { B280 } \\
\text { B612 } \\
\text { B625 } \\
\text { B696 } \\
\end{array}$ & Storage & $2,180 \mathrm{ft}^{3}$ & $\begin{array}{l}128,245 \mathrm{ft}^{3} \\
\text { (storage) }^{\mathrm{d}}\end{array}$ \\
\hline $\begin{array}{l}\text { Mixed TRU } \\
\text { Liquid } \\
\text { Solid }\end{array}$ & $2.47 \mathrm{ft}^{3}$ & $639 \mathrm{ft}^{3}$ & $\begin{array}{l}\text { B233 } \\
\text { B280 } \\
\text { B612 } \\
\text { B625 }\end{array}$ & Storage & $639 \mathrm{ft}^{3}$ & $\begin{array}{l}\text { Included in mixed } \\
\text { LLW storage } \\
\text { capacity figure, } \\
\text { below }\end{array}$ \\
\hline $\begin{array}{l}\text { Low-Level } \\
\text { (LLW) } \\
\text { Liquid } \\
\text { Solid }\end{array}$ & $\begin{array}{l}28,948 \text { gal } \\
6,843 \mathrm{ft}^{3}\end{array}$ & $\begin{array}{l}24,000 \mathrm{gal} \\
13,300 \mathrm{ft}^{3}\end{array}$ & $\begin{array}{l}\text { B233 } \\
\text { B280 } \\
\text { B513/514 } \\
\text { B612 } \\
\text { B614 } \\
\text { B625 } \\
\text { B693 } \\
\text { B696 } \\
\end{array}$ & $\begin{array}{l}\text { Storage and } \\
\text { Treatment }\end{array}$ & $16,504 \mathrm{ft}^{3}$ & $\begin{array}{l}62,516 \mathrm{ft}^{3} / \mathrm{yr} \\
\text { (treatment) } \\
184,937 \mathrm{ft}^{3} \\
\text { (storage) }^{\mathrm{d}}\end{array}$ \\
\hline $\begin{array}{l}\text { Mixed LLW } \\
\text { Liquid } \\
\text { Solid }\end{array}$ & $\begin{array}{l}22,598 \text { gal } \\
844 \mathrm{ft}^{3}\end{array}$ & $\begin{array}{l}12,000 \mathrm{gal} \\
7,660 \mathrm{ft}^{3}\end{array}$ & $\begin{array}{l}\text { B233 } \\
\text { B513/514 } \\
\text { B612 } \\
\text { B614 } \\
\text { B625 } \\
\text { B693 } \\
\end{array}$ & $\begin{array}{l}\text { Storage and } \\
\text { Treatment }\end{array}$ & $9,262 \mathrm{ft}^{3}$ & $\begin{array}{l}35,300 \mathrm{ft}^{3} / \mathrm{yr} \\
\text { (treatment) } \\
99,158 \mathrm{ft}^{3} \\
\text { (storage) }\end{array}$ \\
\hline $\begin{array}{l}\text { Hazandous } \\
\text { Liquid } \\
\text { Solid }\end{array}$ & $\begin{array}{l}107,394 \mathrm{gal} \\
29,929 \mathrm{ft}^{3}\end{array}$ & $\begin{array}{l}4,970 \mathrm{gal} \\
353 \mathrm{ft}^{3}\end{array}$ & $\begin{array}{l}\text { B233 } \\
\text { B513/514 } \\
\text { B612 } \\
\text { B614 } \\
\text { B625 } \\
\text { B693 } \\
\end{array}$ & $\begin{array}{l}\text { Storage and } \\
\text { Treatment } \\
\text {. }\end{array}$ & $1,117 \mathrm{ft}^{3}$ & $\begin{array}{l}35,300 \mathrm{ft}^{3} / \mathrm{yr} \\
\text { (treatment) } \\
99,722 \mathrm{ft}^{3} \\
\text { (storage) }\end{array}$ \\
\hline
\end{tabular}


Table 6. Requested Information for Waste Management (continued)

\begin{tabular}{|c|c|c|c|c|c|c|}
\hline \multirow[b]{2}{*}{$\begin{array}{l}\text { Waste } \\
\text { Category }\end{array}$} & \multirow{2}{*}{$\begin{array}{l}\text { Current } \\
\text { Annual } \\
\text { Generation } \\
\text { Rate }^{\mathbf{2}} \\
\end{array}$} & \multirow[b]{2}{*}{$\begin{array}{l}\text { Amount } \\
\text { in } \\
\text { Inventory }\end{array}$} & \multicolumn{4}{|c|}{ Available TSD Facilities } \\
\hline & & & $\begin{array}{l}\text { Building } \\
\text { Name or } \\
\text { Number }\end{array}$ & $\begin{array}{l}\text { TSD } \\
\text { Method }^{c}\end{array}$ & Inventory $y^{\mathrm{a}}$ & Capacity $^{e}$ \\
\hline $\begin{array}{l}\text { Nonhazardous } \\
\text { (Sanitary) } \\
\text { Liquid } \\
\text { Solid }\end{array}$ & $\begin{array}{l}102,755 \mathrm{gal} \\
2,375 \mathrm{ft}^{3}\end{array}$ & $\begin{array}{l}6,730 \mathrm{gal} \\
101 \mathrm{ft}^{3}\end{array}$ & $\begin{array}{l}\text { B233 } \\
\text { B280 } \\
\text { B513/514 } \\
\text { B612 } \\
\text { B614 } \\
\text { B625 } \\
\text { B693 } \\
\text { B696 } \\
\text { Sanitary } \\
\text { Sewer }\end{array}$ & $\begin{array}{l}\text { Storage and } \\
\text { Treatment }\end{array}$ & $1,000 \mathrm{ft}^{3}$ & 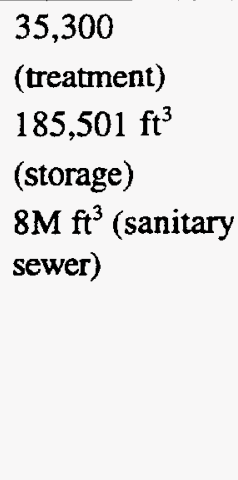 \\
\hline
\end{tabular}

${ }^{a}$ Source: Hazardous Waste Management Division Total Waste Management System Database, Feb. 1998

${ }^{b}$ Source: LLNL Hazardous Waste Management Division, Storage and Disposal Group, April 1998

' Source: Cal EPA, 1997; DOE, 1996b; and LLNL Hazardous Waste Management Division, May 1998.

'The amount of TRU and LLW that can be stored at LLNL's TSD facilities is limited by the amount of curies in the waste and by the capacity of the facilities. For purposes of this table, storage capacity was calculated by adding the total capacity of all the TSD facilities where such waste could be stored if necessary (i.e., the facilities that contain the appropriate administrative and engineering controls required to store TRU and LLW.)

\subsubsection{Waste Management Permit Modifications}

Waste management permit modifications may be required pending completion of the RCRA permitting process.

\subsubsection{Significant Waste Management Issues/Limitations, Agreements, etc.}

DOE and LLNL are working with DTSC to address wastes that are comprised of Californiaonly hazardous wastes combined with radioactive wastes (combined waste). DTSC regulations on combined waste will affect management of radioactive waste that have a Califomia-only hazardous waste constituent.

LLNL is presently operating under an interim status document. LLNL has applied to DTSC for a RCRA Part B permit and is presently working with DTSC to resolve remaining issues. 


\subsection{References}

Cal EPA (California Environmental Protection Agency), Department of Toxic Substances Control, 1997. California Environmental Quality Act Special Initial Study for Approval of a Hazardous Waste Handling Facility Permit for Treatment and Storage of Hazardous Waste, September 1997.

DOE (Department of Energy), 1990. CERCLA Feasibility Study for the LLNL Livermore Site, Livermore, California, December 1990, UCRL-AR-104040.

DOE, 1992a. Final Environmental Impact Statement and Environmental Impact Report for Continued Operation of Lawrence Livermore National Laboratory and Sandia National Laboratories, Livermore,. U.S. Department of Energy, Washington, DC. August 1992 (DOE/EIS-0157, UC EIR SCH\# 90030847),

DOE 1992b. Record of Decision for the Lawrence Livermore national Laboratory Livermore Site, Livermore, California, July 15, 1992, UCRL-AR-109105.

DOE, 1996a. Final Programmatic Environmental Impact Statement for Stockpile Stewardship and Management. DOE/EIS 0236.

DOE, 1996b. Part A Permit for Application for Hazardous Waste Treatment and Storage Facilities, Livermore Site, August 1996 (revised January 1977), prepared by Lawrence Livermore National Laboratory, Environmental Protection Department, UCRL-AR-12372896a.

Hickman, J.C., ed. 1993. The Jepson Manual, Higher Plants of California. University of California Press.

Lazaro, M., et al., 1996. Technical Documentation in Support of the Draft Project-Specific Analysis for Construction and Operation of the National Ignition Facility-Public Comment Draft, Environmental Assessment Division, Argonne National Laboratory, Argonne, IL.

LLNL (Lawrence Livermore National Laboratory), 1997. 1996 Site Annual Environmental Report, Lawrence Livermore National Laboratory, Livermore, California, UCRL-50027-96.

Thorpe, R.K., W. F. Isherwood, M.D. Dresen, and C.P. Webster-Scholten, 1990. CERCLA Remedial Investigation Report for the Livermore Site, Lawrence Livermore National Laboratory, Livermore, CA.

UC (University of California), 1986. Draft Environmental Impact Report for the University of California Contract with the Department of Energy for Operation and Management of Lawrence Livermore National Laboratory, University of California, Berkeley, CA, December, SCH85112611. 



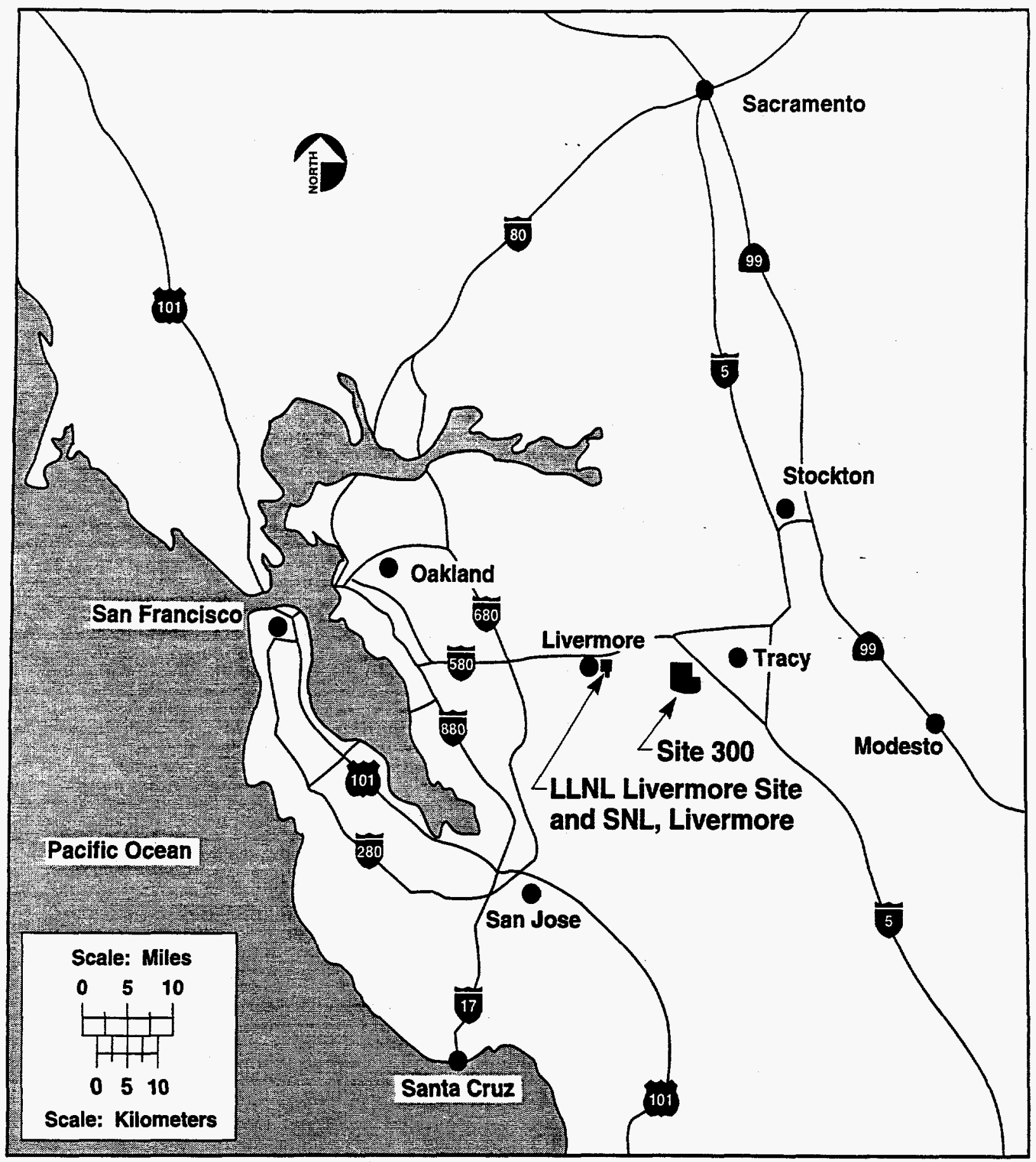

Figure 1. Regional Location of the LLNL Livermore Site 


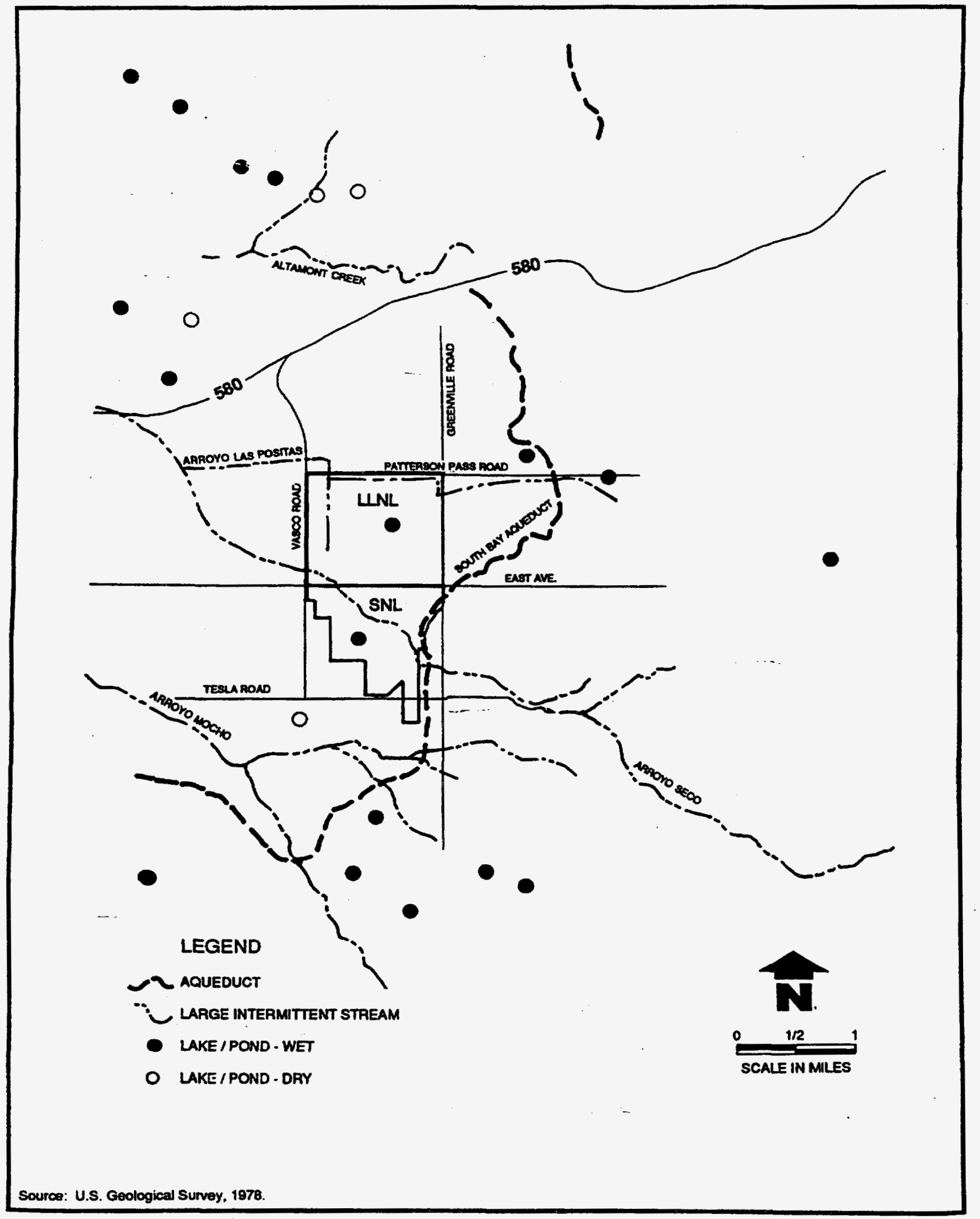

Figure 2. Surfacewater Map for East Livermore Valley 


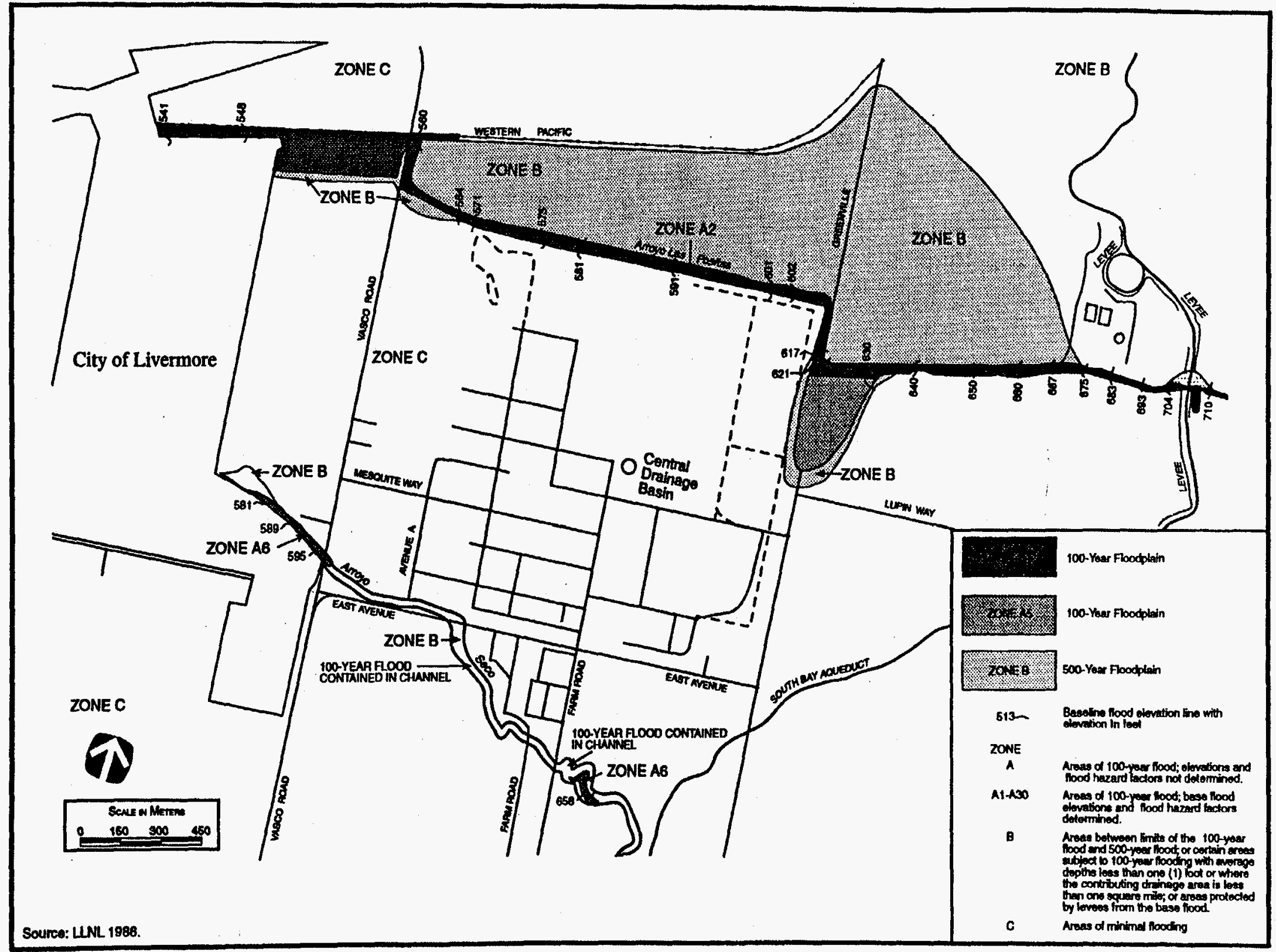

Figure 3. 100-yr and 500 yr Floodplains at the LLNL Livermore Site 

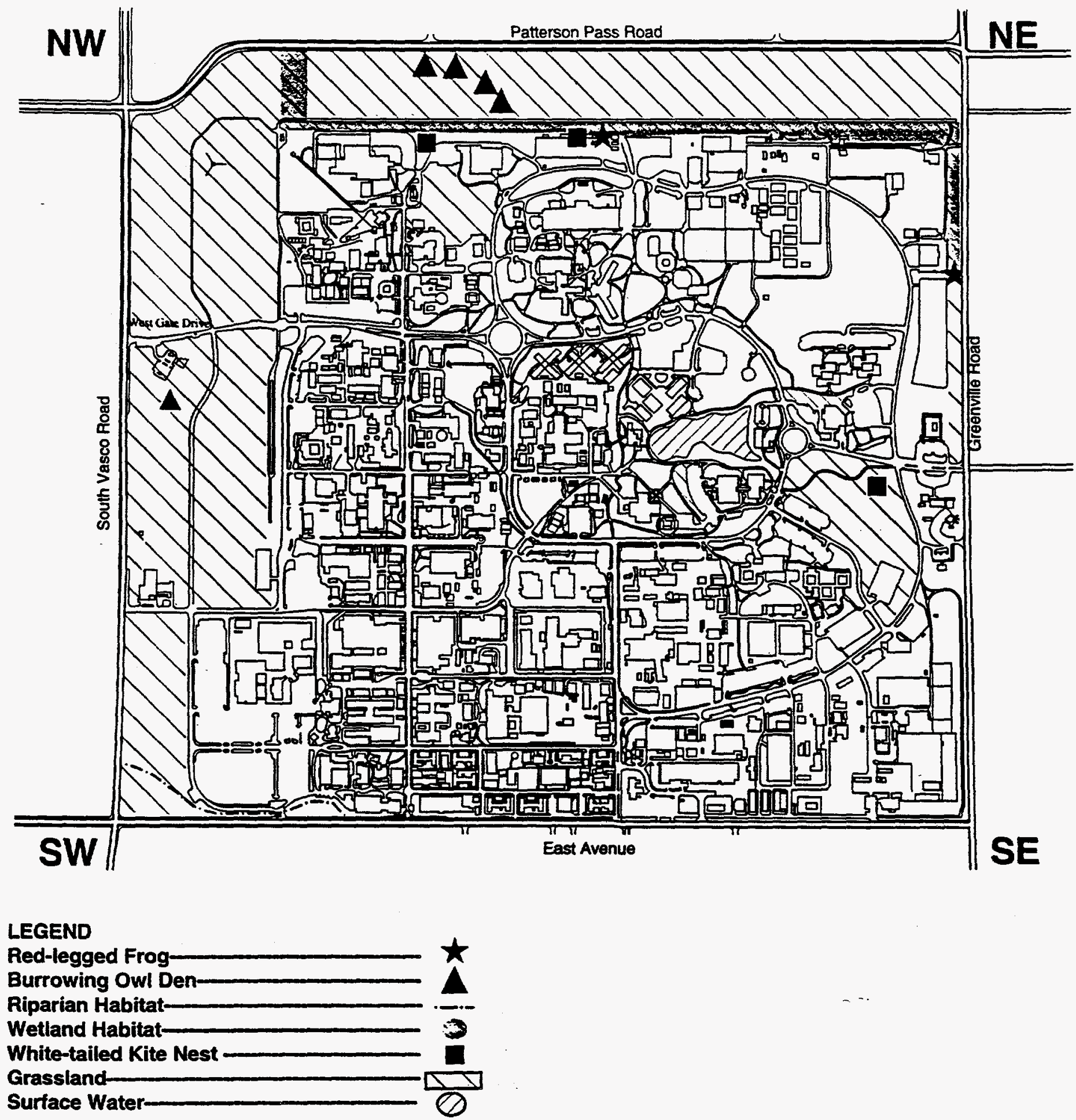


\section{ATTACHMENT 1 \\ LLNL 1996 SITE ANNUAL ENVIRONMENTAL REPORT}

(This information was provided independently by LLNL to SAIC.) 


\section{ATTACHMENT 2 \\ LLNL HOURLY METEOROLOGICAL DATA DISKETTE}

(This information was provided independently by LLNL to SAIC.) 
ATTACHMENT 3

LLNL SENSITIVE SPECIES LIST 
Aftachment 3. Sensitive Species List for Lawrence Livermore National Laboratory Livermore Site.

\begin{tabular}{|c|c|c|c|c|}
\hline Common Name & Scientific Name & $\begin{array}{c}\text { Federal } \\
\text { Status }\end{array}$ & $\begin{array}{l}\text { State } \\
\text { Status }\end{array}$ & $\begin{array}{l}\text { Observed at } \\
\text { LLNL. Main Site }\end{array}$ \\
\hline
\end{tabular}

\section{MAMMALS}

San Joaquin kit fox
Greater western mastiff
Small-footed myotls bat
Long-eared myotls bat
Fringed myotis bat
Long-legged myotis bat
Yuma myotls bat

Pacille western big-eared bet

Vulpes macrotis mutica

\begin{tabular}{|c|c|}
\hline Endangered & Threatened \\
\hline $\mathbf{S C}$ & $s x$ \\
\hline $\boldsymbol{s c}$ & \\
\hline $\boldsymbol{x}$ & \\
\hline$x$ & \\
\hline$S$ & \\
\hline $\mathbf{x}$ & \\
\hline$s$ & $s c$ \\
\hline \multirow[t]{3}{*}{$\boldsymbol{S C}$} & \\
\hline & $s c$ \\
\hline & Protected \\
\hline
\end{tabular}

Eumops perotis callfomicus

Myotis cillolabrum

Myotis evotis

Myotis thysanodes

Myotis volans

Myotis yumanensis

Plecotus lownsendil townsendil

San Franclsco dusky-footed woodrat Neotoma fuscipes annectens

Taxidea taxus

American badger

Fells concolor

Protected

Endangered Endangered

Threatened Threatened

Hallaeetus leucocephalus

Falco mexicanus

Accipiter coopen

Acciplter striatus velox

Falco columbarlus

Speotyto cunicularia hypugea

$\mathbf{s}$

Aslo flammeus

Asio otus

Circus cyaneus

Buteo regalis

Phalocrocrax auritls alboclliatus

Charadrius montanus

Agelaius tricolor

Empidonax trallill brewsteri

Amphispiza belll belll

Aquila chryseatos canadensis

Elanus leucurus

\begin{tabular}{|c|c|}
\hline & $s s c$ \\
\hline & $\operatorname{ssc}$ \\
\hline & $s s c$ \\
\hline & $s s c$ \\
\hline C & 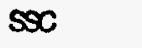 \\
\hline & $\boldsymbol{S S C}$ \\
\hline & $s c$ \\
\hline & $s$ \\
\hline$c$ & $s s$ \\
\hline & $s s c$ \\
\hline & \\
\hline ; & $s x$ \\
\hline & \\
\hline & \\
\hline rotected & Protected \\
\hline & Protected \\
\hline
\end{tabular}

No dens observed on site

No suitable habltat

No sultable habltat

No sultable habltat

No suitable habltat

No sultable habitat

No sultable habitat

No sultable habitat

No sultable habltat

No dens observed on site

No suitable habitat

No sultable habltat

Infrequent transient

Translent

Translent

Translent

Transient

Nesting burrows observed on site

No sultable habitat

No sultable habitat

Transient

Seasonal

Infrequent transient at retention pond

No sultable habitat

Not expected

No sultable habitat

No suitable habitat

Transient

Nesting pairs observed onsite 
Attachment 3. Sensitive Species List for Lawrence Livermore National Laboratory Livermore Sile.

$\begin{array}{lcccc}\text { Common Name } & \text { Scientific Name } & \text { Federal } & \text { State } & \text { Observed at } \\ \text { Status } & \text { Status } & \text { LLNL Main Site } & \text { Comments } & \text { S }\end{array}$

REPTILESAND

\section{AMPHIBIANS}

\begin{tabular}{llllll}
\hline Callfornia red-legged frog & Rana aurora draytoni & Threatened & $\mathbb{S C}$ & Yes & Breeding population In Arroyo Las Posit \\
Callfornia tiger salamander & Ambystoma californiense & Candidate & $\mathbb{S C}$ & No & None observed onsite \\
Foothill yellow-legged frog & Rana boyli & $\mathbb{S C}$ & & No & No suitable habitat \\
Western spadefoot toad & Scaphiopus hammondi & $\mathbb{S}$ & $\mathbb{S C}$ & No & No suitable habitat \\
Northwestern pond turtle & Clemmys mamorata mamorata & $\mathbb{C}$ & & No & No sultable habitat
\end{tabular}

\section{NNERTEBRATES}

\begin{tabular}{lll}
\hline Longhom fairy shrimp & Branchinecta longlantenna & Endangered \\
Vernal pool tadpole shrimp & Lepldurus packardi & Endangered \\
Vernal pool fairy shrimp & Branchinecta lynchi & Threatened \\
Curved-foot hygrotus diving beelle & Hygrotus curvipes & SC
\end{tabular}

No No suitable habitat

No No sultable habitat

No No suitable habitat

Curved-foot hygrotus diving beetle Hygrotus curvpes

No No suitable habltat

\section{PLANTS}

Palmate-bracted blrd's beak

Caper-fruited tropldocarpum

Hispld bird's-beak

Heartscale

Valley spearscale

Brittlescale

Little mousetall

Stinkbells

Alkall milk vetch

Big scale balsamroot

Congdon's tarplant

$\begin{array}{ll}\text { Cordylanthus palmatus } & \text { Endang } \\ \text { Tropidocarpum capparideum } & \mathbb{C} \\ \text { Cordylanthus mollis ssp. hispldus } & \mathbb{C} \\ \text { Atriplex cordulata } & \mathbb{C} \\ \text { Atriplex joaquinlana } & \mathbb{C} \\ \text { Atriplex depressa } & \mathbb{C} \\ \text { Myosunis minimus ssp. apus } & \mathbb{C} \\ \text { Frtillaria agrestls } & \\ \text { Astragalus tener tener } & \\ \text { Balsamorhiza macrolepls var. macrolepls } \\ \text { Hemizonia parni ssp. congdonli }\end{array}$

Endangered Endangered

$\mathbf{x}$

$\boldsymbol{s c}$

$\boldsymbol{s c}$

$\mathbf{s}$

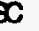

C

$\mathfrak{s c}$

$\operatorname{ssc}$

$\operatorname{scc}$

$\operatorname{ssc}$
No No suitable habitat

No No suitbale habitat, presumed extinct

No No suitable habltat

No No suitable habitat

No No suitable habltat

No No sultable habitat

No No sultable habltat

No No sultable habitat

No . No sultable habitat

No No suitable habitat

No No suitable habitat 


\section{INTERNAL DISTRIBUTION}
1. J. J. Carbajo
2. B. S. Cowell
3. S. E. Fisher
4. E. C. Fox
5. R. G. Gilliland
6. S. R. Greene
7. S. A. Hodge
8. R. Holdaway
9. S. B. Ludwig
10. G. T. Mays
11. K. L. McElhaney
12. G. E. Michaels
13. R. N. Morris

\author{
14. D. L. Moses \\ 15. D. G. O'Connor \\ 16. R. T. Primm III \\ 17. R. R. Rahn \\ 18. J. D. Sease \\ 19. C. C. Southmayd \\ 20. V.S. White \\ 21. C. K. Williams \\ 22. D. L. Williams, Jr. \\ 23. Central Research Library \\ 24-25. ORNL Laboratory Records (OSTI) \\ 26. ORNL Laboratory Records-RC
}

\section{EXTERNAL DISTRIBUTION}

27. M. C. Bronson, Lawrence Livermore National Laboratory, P.O. Box 808, MS L-394, Livermore, CA 94551.

28. W. G. Brough, Lawrence Livermore National Laboratory, P.O. Box 808, MS L-394, Livermore, CA 94551.

29. H. R. Canter, U.S. Department of Energy, MD-3, 1000 Independence Avenue SW, Washington, DC 20585.

30. J. Eichner, Science Applications International Corp., 20201 Century Blvd., Germantown, MD 20874.

31. K. Gandee, U.S. Department of Energy, MD-4, 1000 Independence Avenue SW, Washington, DC 20585.

32. C. Groome, Science Applications International Corp., 20201 Century Blvd., Germantown, MD 20874.

33. D. Hirrlinger, Science Applications International Corp., 20201 Century Blvd., Germantown, MD 20874.

34. J. V. Johnson, U.S. Department of Energy, MD-4, 1000 Independence Avenue SW, Washington, DC 20585.

35. H. Kahn, Lawrence Livermore National Laboratory, P.O. Box 808, MS L-627, Livermore, CA 94551.

36. T. Kato, Lawrence Livermore National Laboratory, P.O. Box 808, MS L-627, Livermore, CA 94551.

37. C. Kielusiak, Lawrence Livermore National Laboratory, P.O. Box 808, MS L-627, Livermore, CA 94551.

38. D. J. Nulton, U.S. Department of Energy, MD-4, 1000 Independence Avenue SW, Washington, DC 20585.

39. D. Peko, U.S. Department of Energy, MD-3, 1000 Independence Avenue SW, Washington, DC 20585.

40. P. T. Rhoads, U.S. Department of Energy, MD-3, 1000 Independence Avenue SW, Washington, DC 20585.

41. G. B. Stevenson, U.S. Department of Energy, MD-4, 1000 Independence Avenue SW, Washington, DC 20585.

42. J. H. Thompson, U.S. Department of Energy, MD-4, 1000 Independence Avenue SW, Washington, DC 20585.

43. T. H. Wynn, U.S. Department of Energy, ORO, P.O. Box 2001, Oak Ridge, TN 37831-8283. 


\section{DOE PUBLIC READING ROOMS}

44. Albuquerque Operations Office, TV1 Community College Library, Montoya Campus, 4700 Morris, NE, Albuquerque, NM 87111.

45. Amarillo Area Office, U.S. Department of Energy, Amarillo College, Lynn Library/Learning Center, 2201 South Washington, P.O. Box 447, Amarillo, TX 79178.

46. U.S. DOE Reading Room, Carson County Library, 401 Main Street, P.O. Box 339, Panhandle, TX 79068.

47. Chicago Operations Office, Office of the Manager/Communications, U.S. Department of Energy, 9800 South Cass Avenue, Argonne, IL 60439.

48. Idaho National Engineering and Environmental Laboratory, Idaho Public Reading Room, 1776 Science Center Drive, Idaho Falls, ID 83402.

49. Los Alamos National Laboratory, U.S. Department of Energy, c/o Los Alamos Community Reading Room, 1350 Central, Suite 101, Los Alamos, NM 87544.

50. Nevada Operations Office, U.S. Department of Energy, Public Reading Room, 2621 Losse Road, North Las Vegas, NV 89030.

51. Oak Ridge Operations Office, U.S. Department of Energy, Public Reading Room, 200 Administration Road, Room G-217, Oak Ridge, TN 37831-8501.

52. Richland Operations Office, DOE Public Reading Room, 100 Sprout Road, Room 130 West, P.O. Box 999, M/S H2-53, Richland, WA 99352.

53. Rocky Flats Office, Front Range Community College Library, 3645 West 112 th Avenue, Westminster, CO 80030 .

54. Sandia National Laboratory/CA, Livermore Public Library, 1000 S. Livermore Avenue, Livermore, CA 94550 .

55. Savannah River Operations Office, Gregg-Graniteville Library, University of South Carolina-Aiken, 171 University Parkway, Aiken, SC 29801.

56. U.S. Department of Energy, Freedom of Information/Privacy Act Public Reading Room, Forrestal Building, Room 1E-190, 1000 Independence Avenue SW, Washington, DC 20585. 